\title{
The Energy-Savings Potential of Electrochromic Windows in the US Commercial Buildings Sector
}

\author{
E.S. Lee ${ }^{*}$, M. Yazdanian, S.E. Selkowitz \\ Building Technologies Program, Environmental Energy Technologies Division, Lawrence Berkeley \\ National Laboratory, Mailstop 90-3111, 1 Cyclotron Road, Berkeley, CA 94720, USA
}

\begin{abstract}
Switchable electrochromic (EC) windows have been projected to significantly reduce the energy use of buildings nationwide. This study quantifies the potential impact of electrochromic windows on US primary energy use in the commercial building sector and also provides a broader database of energy use and peak demand savings for perimeter zones than that given in previous LBNL simulation studies. The DOE-2.1E building simulation program was used to predict the annual energy use of a three-storey prototypical commercial office building located in five US climates and 16 California climate zones. The energy performance of an electrochromic window controlled to maintain daylight illuminance at a prescribed setpoint level is compared to conventional and the best available commercial windows as well as windows defined by the ASHRAE 90.1-1999 and California Title 24-2005 Prescriptive Standards. Perimeter zone energy use and peak demand savings data by orientation, window size, and climate are given for windows with interior shading, attached shading, and horizon obstructions (to simulate an urban environment).

Perimeter zone primary energy use is reduced by $10-20 \%$ in east, south, and west zones in most climates if the commercial building has a large window-to-wall area ratio of 0.60 compared to a spectrally selective low-e window with daylighting controls and no interior or exterior shading. Peak demand for the same condition is reduced by $20-30 \%$. The emerging electrochromic window with daylighting controls is projected to save approximately 91.5-97.3 $10^{12}$ Btu in the year 2030 compared to a spectrally selective lowE window with manually-controlled interior shades and no daylighting controls if it reaches a $40 \%$ market penetration level in that year.
\end{abstract}

Keywords: Building energy-efficiency, electrochromic windows, daylighting controls, primary energy use, peak demand.

\section{Introduction}

In 2002, the US Department of Energy (DOE) worked with members of the window industry to create a roadmap that helped define the technologies and tools that will be needed to create and sell the next generation of windows in the $21^{\text {st }}$ century [1]. Window industry executives identified a new generation of dynamic, responsive "Smart Windows" as the number one top priority. Smart windows include

chromogenic glazings that can be reversibly switched from a clear to a transparent, colored state by means of a small applied voltage, resulting in thermal and optical properties that can be dynamically controlled. "Smart windows" incorporating electrochromic glazings could reduce peak electric loads significantly in many commercial buildings and provide added daylighting benefits throughout the US, as well as improve

* Corresponding author. Tel.: +1-510-486-4997; fax: +1-510-486-4089. Email address: eslee@lbl.gov (E.S.Lee). 
comfort and enhance productivity in our homes and offices. These technologies can provide maximum flexibility in aggressively managing energy use in buildings in the emerging deregulated utility

environment and could move the building community toward the goal of producing advanced buildings that have minimal impact on the nation's energy resources. Customer choice will be further enhanced by the flexibility to dynamically control envelope-driven cooling and lighting loads.

DOE and other publicly funded agencies need to invest taxpayers' dollars wisely toward new energyefficiency technologies that offer significant potential to reduce US dependence on foreign oil. Among the variety of criteria used to determine the potential of a new technology, impact assessments are used to forecast the potential reduction in total US primary energy consumption given practical factors such as product cost, applicability to building type, and market penetration rates. These assessments are made periodically as the technology matures from concept to near-market introduction and can help stakeholders rank the importance of a heterogeneous mix of technologies that vie for R\&D resources.

Building simulations have been performed using initially theoretical then measured spectral data to evaluate the energy performance of EC windows in commercial buildings [2-3]. This early work tracked the conceptual stages of EC R\&D and provided feedback and focus for material scientists working on coating development. Among other issues, these studies served to quantify the importance of switching range and absorptive versus reflective solar-optical switching modes. Additional simulation studies were conducted to better understand how switchable windows should be controlled, such as what triggering functions (incident solar, daylight, etc.) should be used and when or at what levels [4-6]. Full-scale tests have led to a greater appreciation of potential occupant satisfaction and acceptance issues and have yielded limited lighting energy performance data given integrated window-lighting control systems [8]. Additional studies to better understand the performance of such windows in real-world applications are underway or have been completed through the IEA Task 27 activity [9], SWIFT [10], and CEC-DOE field test program [11].

This study broadens early simulation studies by modeling a wide range of conditions. It also estimates the potential savings in US primary energy consumption resulting from the emerging electrochromic window technology. The DOE-2 building energy simulation program was used to determine annual energy use and peak demand savings of electrochromic windows with daylighting controls relative to several base case window conditions. These data are given for sixteen California climate zones and six national climates for a prototypical commercial office building. Several market penetration rate scenarios were considered. Gross estimates of US primary energy use savings are given to the year 2030 for these various scenarios.

\section{Method}

\subsection{Building Module}

Building energy simulations of commercial window systems were performed using the DOE-2.1E building energy simulation program [12]. The DOE-2.1E program is the building industry standard that requires as input a geometrical description of the building and a physical description of the building construction, mechanical equipment, end-use load schedules, utility rates, and hourly weather data to determine the energy consumption of the building. DOE-2 has been used to develop ASHRAE and California Title-24 Energy Standards and to design many commercial buildings over the past 20 years. EnergyPlus is a new building performance simulation program, released in April 2001, that combines the best capabilities and features from BLAST and DOE-2.1E along with new capabilities [13]. While there are differences between the two programs, EnergyPlus and DOE-2.1E use the same basic algorithms for the window load calculations. Relative performance trends and conclusions drawn from this analysis with DOE-2.1E are expected to be the same as those from EnergyPlus.

A generic commercial office building prototype, originally developed by LBNL for ASHRAE SP-41, was used for this study. The prototype was modified by PNNL [14] in support of the ASHRAE Standard 90.1-1989 non-residential building energy standards, then further modified by LBNL for this study to reflect ASHRAE Standard 90.1-1999 [15] and the California Energy Commission (CEC) Title 24-2001 Energy Efficiency Standards for Nonresidential Buildings [16]. The ASHRAE 90.1-2001 Standard did not change the window performance requirements. As of January 2004, ASHRAE 90.1-1999 has been or is 
being adopted by 18 states in the US while ASHRAE 90.1-2001 has been adopted by five states in the US [17]. The CEC Title 24-2005 Standard was phased in starting 2003 and had no substantive changes from the 2001 Standard that would affect this analysis. The prototype is a synthetic hypothetical building, not a physically real building, with size, shell construction, HVAC system type, operating schedules, etc. based on the mean prevailing condition among statistical samples and engineering judgment. The analysis in this report relies on relative performance differences between window systems; the intention is not to provide absolute data from which a reader may determine energy performance for a specific building.

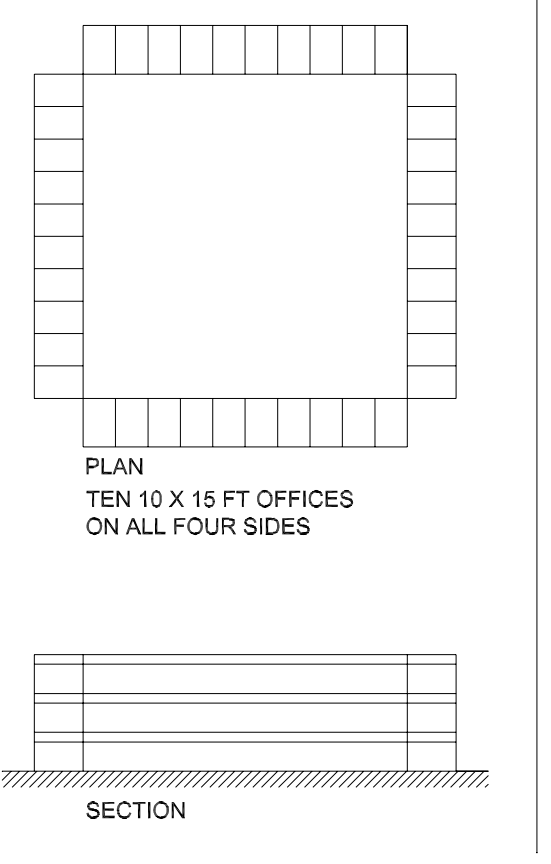

Fig. 1. Floor plan and section of the three storey commercial building prototype.

The three-storey prototype consists of a ground, intermediate, and rooftop floor (Figure 1). Each floor has four $139 \mathrm{~m}^{2}\left(1500 \mathrm{ft}^{2}\right)$ perimeter zones, each consisting of ten 3.04-m wide by $4.6-\mathrm{m}$ deep $(10 \mathrm{ft} \mathrm{x} 15 \mathrm{ft})$ private offices, and a $30.5 \times 30.5 \mathrm{~m}(100 \times 100 \mathrm{ft})$ square core zone with a floor area of $929 \mathrm{~m}^{2}\left(10,000 \mathrm{ft}^{2}\right)$. The floor-to-floor height is $3.66 \mathrm{~m}(12 \mathrm{ft})$ with a $2.74 \mathrm{~m}(9 \mathrm{ft})$ high ceiling and a $0.91-\mathrm{m}(3-\mathrm{ft})$ high, unconditioned plenum. The total floor area of the model is $4459 \mathrm{~m}^{2}\left(48,000 \mathrm{ft}^{2}\right)$. The building was oriented true north with each facade facing the four cardinal directions.

Light-weight construction was used for the building and was the same for each climate modeled: 10cm (4-in.) brick exterior facade, built-up roofing over a 1.9-cm (0.75-in.) plywood deck, and a carpeted, 15.24-cm (6-in.) heavy-weight concrete slab on grade. Insulation values for the exterior wall, roof, and floor were obtained from ASHRAE Standard 90.1-1999 and Title 24-2005. An effective U-value was applied to account for the slab-to-ground-contact temperature variations of the soil.

The interior was specified with adiabatic walls between perimeter offices and standard walls between the perimeter and core zone. These walls were composed of $1.59 \mathrm{~cm}(0.625 \mathrm{in}$.) gypsum and metal studs. A $1.27-\mathrm{cm}(0.5-\mathrm{in}$.) acoustical tile ceiling was specified for all occupied zones and 0.42-cm (0.167-in.) light-weight concrete floors with a carpet were specified for the two upper level floors.

Peak occupant density was $36.2 \mathrm{~m}^{2}\left(390 \mathrm{ft}^{2}\right)$ per person in the core zones and $25.5 \mathrm{~m}^{2}\left(275 \mathrm{ft}^{2}\right)$ per person in the perimeter zones. Peak equipment loads were $0.07 \mathrm{~W} / \mathrm{m}^{2}\left(0.75 \mathrm{~W} / \mathrm{ft}^{2}\right)$. Schedules corresponded to data from ASHRAE 90.1-1989 and other field studies. Outside air requirements were 0.15 $\mathrm{cfm} / \mathrm{ft}^{2}$ in compliance with ASHRAE 62-1989 [18]. 
Simulations were made for 26 climates (Tables 1-2, Figures 2-3). Six national climates were modeled corresponding to the DOE Energy Information Agency climate zones [19]. TMY2 weather tapes were used for all national climates. Sixteen California climates were modeled corresponding to the Title-24 climate designations using CEC distributed unmodified WYEC weather tapes.
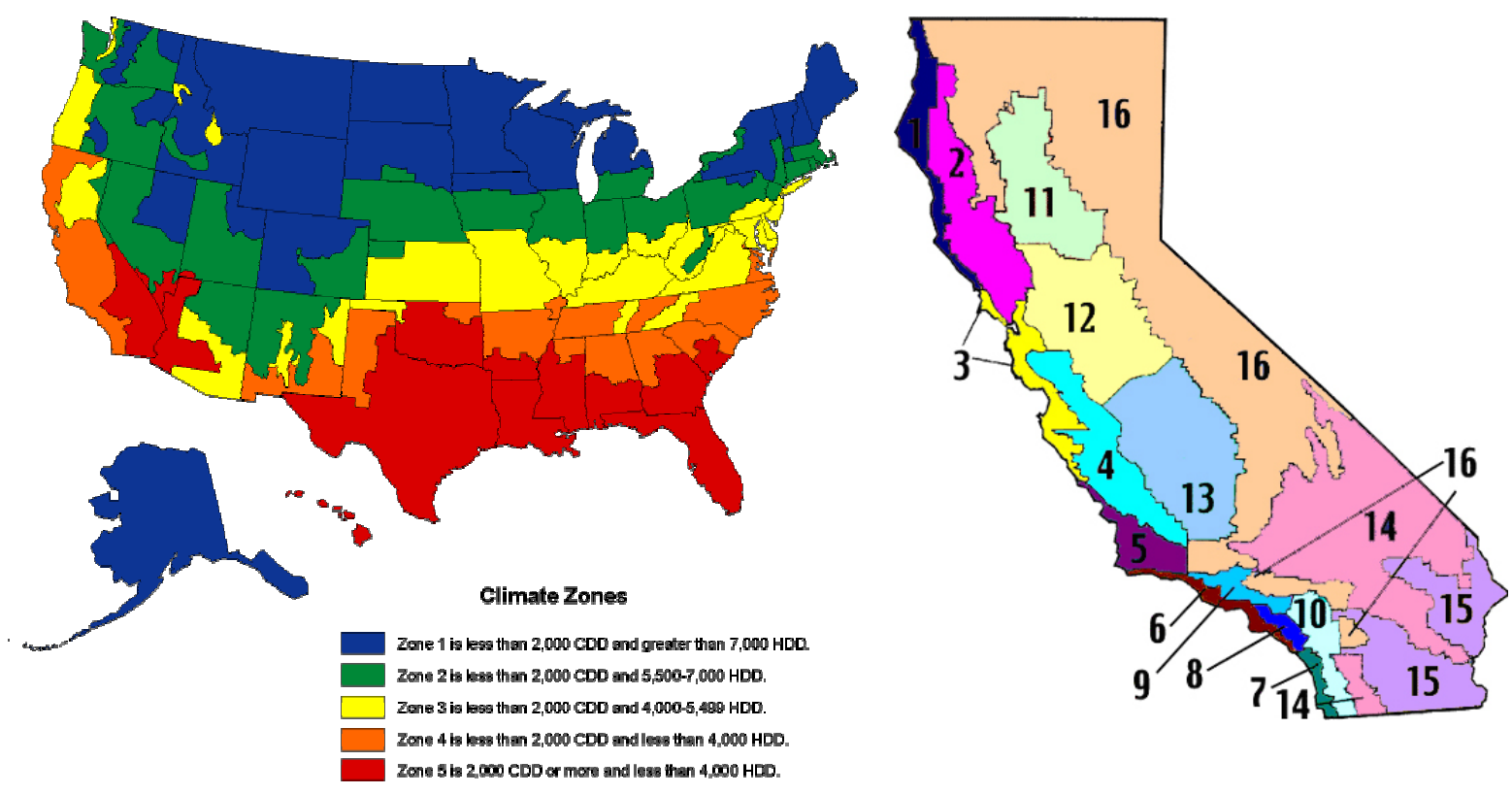

Fig. 2. US climate zones defined by CBECS 1999.

Fig. 3 California climate zones defined by CEC.

Table 1

US Climate Zones

\begin{tabular}{|c|c|c|c|c|c|c|c|c|c|}
\hline HDD65 & CDD50 & $\begin{array}{r}\text { Latitude I } \\
\left({ }^{\circ}\right)\end{array}$ & $\begin{array}{r}\text { itude } \\
\left({ }^{\circ}\right)\end{array}$ & $\begin{array}{r}\text { ation } \\
(\mathrm{ft})\end{array}$ & $\begin{array}{r}\mathrm{HDT} \\
\left({ }^{\circ} \mathrm{F}\right)\end{array}$ & $\begin{array}{r}\text { CDT } \\
\text { DBT } \\
\left({ }^{\circ} \mathrm{F}\right) \\
\end{array}$ & $\begin{array}{r}\text { CDT } \\
\text { WBT } \\
\left({ }^{\circ} \mathrm{F}\right) \\
\end{array}$ & $\mathrm{N}$ & $\begin{array}{r}\text { Hrs } \\
\text { Sun up }\end{array}$ \\
\hline 7981 & 2680 & 44.88 & 93.22 & 834 & -16 & 88 & 71 & 566 & 4756 \\
\hline 6536 & 2941 & 41.98 & 87.90 & 674 & -6 & 88 & 73 & 613 & 4757 \\
\hline 4820 & 3709 & 38.90 & 77.00 & 14 & 11 & 91 & 74 & N.A. & 4750 \\
\hline 2991 & 5038 & 33.65 & 84.43 & 1010 & 18 & 91 & 74 & 1849 & 4747 \\
\hline 1599 & 6876 & 29.97 & 95.35 & 96 & 29 & 93 & 77 & N.A. & 4755 \\
\hline 1350 & 8425 & 33.43 & 112.02 & 1110 & 34 & 108 & 70 & 746 & 4756 \\
\hline
\end{tabular}

Notes: HDT: Heating design temperature (99.6\%); CDT: Cooling design temperature (1.0\%); N: number of hours between 8:00-16:00 when 55<Tdbt $<69^{\circ} \mathrm{F}$; N.A.: Not available; Washington DC's HDT, WBT, DBT, and N values are for Baltimore, Maryland; Hrs Sun Up: number of hours sun is up and maximum number of hours shade could be deployed. 
Table 2

California Climate Zones

\begin{tabular}{lrrrr}
\hline City & $\begin{array}{r}\text { Zone } \\
\text { Arcata }\end{array}$ & $\begin{array}{r}\text { Latitude } \\
\left({ }^{\circ}\right)\end{array}$ & $\begin{array}{r}\text { Longitude } \\
\left({ }^{\circ}\right)\end{array}$ & $\begin{array}{r}\text { Altitude } \\
(\mathrm{ft})\end{array}$ \\
Santa Rosa & 1 & 41.0 & 124.10 & 218 \\
Oakland & 3 & 38.5 & 122.82 & 167 \\
Sunnyvale & 4 & 37.7 & 122.20 & 6 \\
Santa Maria & 5 & 34.9 & 122.03 & 97 \\
Long Beach & 6 & 33.8 & 118.23 & 236 \\
San Diego & 7 & 32.7 & 117.17 & 25 \\
El Toro & 8 & 33.7 & 117.73 & 380 \\
Pasadena & 9 & 34.2 & 118.15 & 864 \\
Riverside & 10 & 34.0 & 117.38 & 840 \\
Red Bluff & 11 & 40.2 & 122.25 & 342 \\
Sacramento & 12 & 38.5 & 121.50 & 17 \\
Fresno & 13 & 36.8 & 119.72 & 328 \\
China Lake & 14 & 35.7 & 117.68 & 2220 \\
El Centro & 15 & 32.8 & 115.57 & -30 \\
Mount Shasta & 16 & 41.3 & 122.32 & 3535 \\
\hline
\end{tabular}

\subsection{Windows}

Flush-mounted, non-operable windows were modeled in the exterior wall of each perimeter zone office. Five window sizes were modeled with a fenestration window-to-wall area ratio (WWR) (which includes the area of the whole window with frame), of $0.0,0.15,0.30,0.45$, and 0.60 , where the wall area was defined as the floor-to-floor exterior wall area and the floor-to-floor height was $3.66 \mathrm{~m}$ (12 ft). Note, the ASHRAE Standard 90.1-1999 uses this definition; however in previous LBNL research, WWR was based on the glazed window area (see Table 3 for equivalent WWRg values). Figure 4 gives the position of the window in the window wall as seen from the exterior. Window position can influence the distribution of heat flux to interior room surfaces and the distribution of daylight within the room. The head height of the framed window was set flush with the ceiling at $2.74 \mathrm{~m}(9 \mathrm{ft})$ for all glazing areas except WWR=0.15.

Several types of commercially-available glazings were defined using LBNL Window5, Therm, and Optics simulation programs (Table 4). The single-pane window (type A) had a non-thermally-broken, aluminum frame (assuming a retrofit condition) while all double-pane windows had a thermally-broken, aluminum frame. The 3-pane and 4-pane windows had aluminum inner and outer frames with a polyamide thermal break between the outer and inner frames. Multi-pane windows were modeled with aluminum spacer or insulated spacers, as indicated in Table 4. Frame width increased with window area. For WWR $=0.15$, the frame width was 3.18-cm (1.25-in.) wide and for WWR=0.30-0.60, the frame width was 7.62-cm (3-in.) wide. For multi-pane windows, all gaps were filled with air. The gap width was $1.27 \mathrm{~cm}$ ( 0.5 in.) for double-pane windows and $2 \mathrm{~cm}$ ( 0.79 in.) for triple-pane. For the 4-pane window, the outer gap was $2.5 \mathrm{~cm}$ ( $1 \mathrm{in}$.) and the remaining were $2 \mathrm{~cm}$ (0.79 in.) wide. The intermediate layers for the 3- and 4-layer windows were suspended, clear polyethylene (PET) films.

ASHRAE and CEC Title-24 prescribed windows were modeled with fixed solar heat gain coefficient (SHGC) and U-factor values dictated by the codes (Table 5-6) using the conceptual design feature in DOE2 to model hypothetical windows. This feature allows one to specify the shading coefficient (SC=SHGC/0.87) and U-factor of a hypothetical window. Reverse engineering an actual window using actual spectral data and Window5 to match the prescribed SHGC and U-factor does not allow one to match the prescribed values exactly. The visible transmittance was left unspecified since daylighting controls were not modeled. 
a)

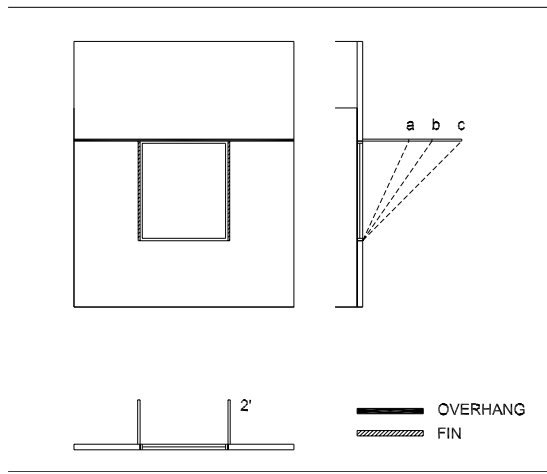

c)

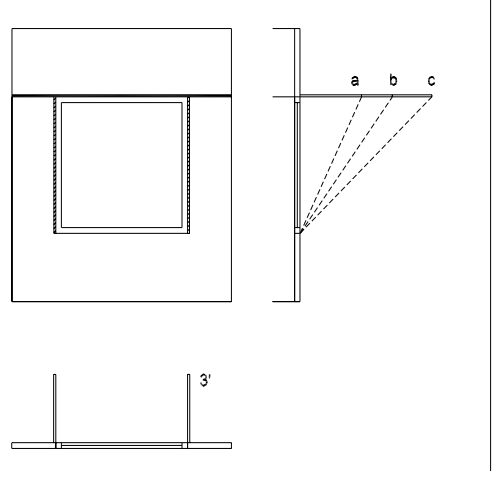

b)

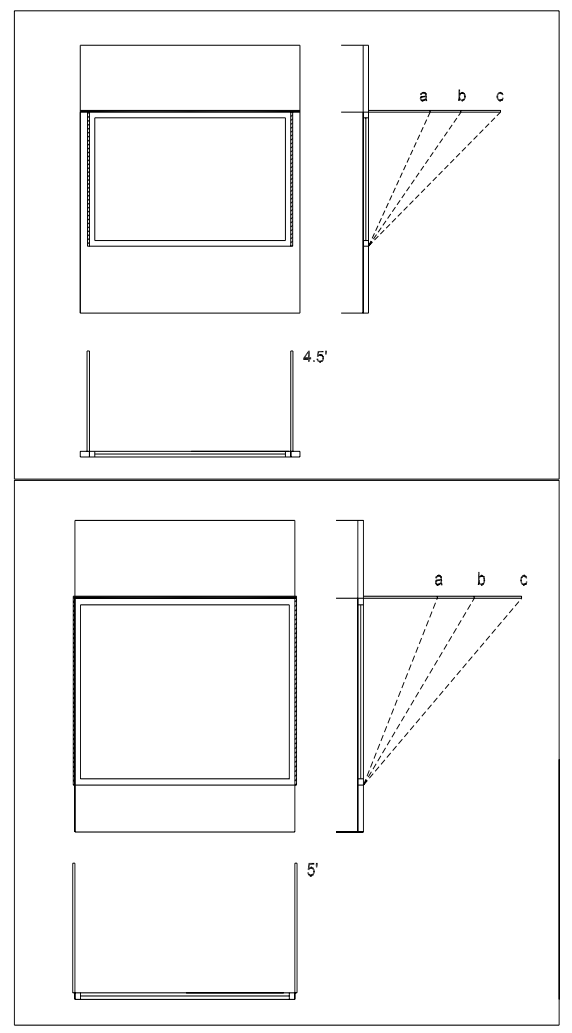

Fig.. 4. Elevation view of the window wall for window-to-wall ratios (WWR) of a) 0.15 , b) 0.30 , c) 0.45 , and d) 0.60 (top to bottom). Sections through the overhang and fin are given to the right of each elevation.

Table 3

Window placement in a private office

\begin{tabular}{rrrrrrrr}
\hline WWR & $\begin{array}{r}\text { Window } \\
\text { Height } \\
\mathrm{ft}\end{array}$ & $\begin{array}{r}\text { Window } \\
\text { Width } \\
\mathrm{ft}\end{array}$ & $\begin{array}{r}\text { Window } \\
\text { Sill Height } \\
\mathrm{ft}\end{array}$ & $\begin{array}{r}\text { Area } \\
\text { Window } \\
\mathrm{ft}^{2}\end{array}$ & $\begin{array}{r}\text { Frame } \\
\text { Width } \\
\text { inches }\end{array}$ & $\begin{array}{r}\text { Area } \\
\text { Glass }\end{array}$ & WWRg \\
$\mathrm{ft}^{2}$ & \\
\hline 0.00 & 0.0 & 0.0 & 0.0 & 0 & 0.00 & 0.00 & 0.00 \\
0.15 & 4.5 & 4.0 & 3.0 & 18 & 1.25 & 16.27 & 0.14 \\
0.30 & 6.0 & 6.0 & 3.0 & 36 & 3.00 & 30.25 & 0.25 \\
0.45 & 6.0 & 9.0 & 3.0 & 54 & 3.00 & 46.75 & 0.39 \\
0.60 & 7.2 & 10.0 & 1.8 & 72 & 3.00 & 63.65 & 0.53 \\
\hline
\end{tabular}


Table 4

Window properties

\begin{tabular}{|c|c|c|c|c|c|c|c|c|c|c|c|}
\hline & Description & Inner Layer & $\begin{array}{r}\text { U-Factor } \\
\text { Btu/h- } \\
\mathrm{ft}^{2}-{ }^{\circ} \mathrm{F} \\
\text { (Overall) }\end{array}$ & $\begin{array}{r}\text { U-Factor } \\
\text { Btu/h- } \\
\mathrm{ft}^{2}-{ }^{\circ} \mathrm{F} \\
(\mathrm{COG})\end{array}$ & SHGC & SHGC & (Overall) & $(\mathrm{COG})$ & & $\begin{array}{r}\text { Frame } \\
\text { U-value } \\
\text { Btu/ } \\
\text { h-ftt }{ }^{2}{ }^{\circ} \mathrm{F}\end{array}$ & Spacers \\
\hline $\bar{A}$ & Clear & & 1.25 & 1.09 & 0.72 & 0.82 & 0.71 & 0.88 & 97.9 & 1.90 & None \\
\hline B & Clear & Clear & 0.60 & 0.48 & 0.60 & 0.70 & 0.63 & 0.78 & 95.7 & 1.00 & Alum \\
\hline $\mathrm{C}$ & Bronze Tint & Clear & 0.60 & 0.48 & 0.42 & 0.49 & 0.38 & 0.48 & 95.2 & 1.00 & Alum \\
\hline D & Reflective & Clear & 0.54 & 0.40 & 0.17 & 0.17 & 0.10 & 0.13 & 96.1 & 1.00 & Alum \\
\hline E & Bronze Tint & Clear L & 0.49 & 0.33 & 0.39 & 0.44 & 0.36 & 0.44 & 94.1 & 1.00 & Alum \\
\hline F & Evergreen Tint & Clear S & 0.46 & 0.29 & 0.27 & 0.29 & 0.43 & 0.53 & 85.2 & 1.00 & Alum \\
\hline G & Clear Selective Low-E & Clear & 0.46 & 0.29 & 0.34 & 0.38 & 0.57 & 0.71 & 95.4 & 1.00 & Alum \\
\hline $\mathrm{H}$ & Clear Low-E + 1 PET layer & Clear Lo & 0.20 & 0.15 & 0.22 & 0.26 & 0.37 & 0.46 & 88.2 & 0.35 & Insul \\
\hline 1 & Clear Low-E + 2 PET layers & Clear Low-E & 0.14 & 0.13 & 0.20 & 0.24 & 0.34 & 0.42 & 89.4 & 0.18 & Insul \\
\hline $\mathrm{J} 1$ & Bleached electrochromic & Clear & 0.49 & 0.33 & 0.37 & 0.42 & 0.45 & 0.56 & 92.7 & 1.00 & Alum \\
\hline $\mathrm{J} 2$ & Colored electrochromic & Clear & 0.49 & 0.33 & 0.10 & 0.09 & 0.02 & 0.02 & 52.3 & 1.00 & Alum \\
\hline
\end{tabular}

Notes: COG: Center-of-glass; CRI: Color rendering index; EC: electrochromic glazing; low-E: low emissivity; PET: spectrally-selective polyethylene layer; SHGC: solar heat gain coefficient; Sel.: spectrally-selective; Alum: aluminum; Insul: insulating. U-values are given for ASHRAE winter conditions. Overall U-values are given for a window whose overall dimensions including frame are $4 \times 6 \mathrm{ft}$ (3-in frame). SHGC computed for ASHRAE summer conditions. All properties determine using WINDOW4.1 and Optics5 (v.2.0.2).

Table 5

ASHRAE 90.1-1999 Prescriptive Window Properties

\begin{tabular}{|c|c|c|c|c|c|c|}
\hline \multicolumn{2}{|c|}{ Window-to-wall ratio (WWR): } & \multirow[t]{2}{*}{$0-10$} & \multirow[t]{2}{*}{$10.1-20$} & \multirow[t]{2}{*}{$20.1-30$} & \multirow[t]{2}{*}{$30.1-40$} & \multirow[t]{2}{*}{$40.1-50$} \\
\hline \multicolumn{2}{|c|}{ Assembly maximum SHGC: } & & & & & \\
\hline \multirow[t]{2}{*}{ Minneapolis } & SHGC max & 0.49 & 0.39 & 0.39 & 0.39 & 0.26 \\
\hline & SHGC north & 0.49 & 0.49 & 0.49 & 0.49 & 0.49 \\
\hline \multirow[t]{2}{*}{ Chicago } & SHGC max & 0.49 & 0.39 & 0.39 & 0.39 & 0.26 \\
\hline & SHGC north & 0.49 & 0.49 & 0.49 & 0.49 & 0.36 \\
\hline \multirow[t]{2}{*}{ Washington DC } & SHGC max & 0.39 & 0.39 & 0.39 & 0.39 & 0.25 \\
\hline & SHGC north & 0.49 & 0.49 & 0.49 & 0.49 & 0.36 \\
\hline \multirow{2}{*}{ Los Angeles } & SHGC max & 0.61 & 0.61 & 0.44 & 0.44 & 0.31 \\
\hline & SHGC north & 0.82 & 0.61 & 0.61 & 0.61 & 0.39 \\
\hline \multirow{2}{*}{ Houston } & SHGC max & 0.39 & 0.25 & 0.25 & 0.25 & 0.17 \\
\hline & SHGC north & 0.61 & 0.61 & 0.61 & 0.61 & 0.42 \\
\hline \multirow{2}{*}{ Phoenix } & SHGC max & 0.25 & 0.25 & 0.25 & 0.25 & 0.17 \\
\hline & SHGC north & 0.61 & 0.61 & 0.61 & 0.61 & 0.44 \\
\hline \multicolumn{7}{|c|}{ Assembly maximum U-value (Btu/h- $\left.\mathrm{ft}^{2}-{ }^{\circ} \mathrm{F}\right)$ for fixed windows: } \\
\hline \multicolumn{2}{|l|}{ Minneapolis } & 0.57 & 0.57 & 0.57 & 0.57 & 0.46 \\
\hline \multicolumn{2}{|l|}{ Chicago } & 0.57 & 0.57 & 0.57 & 0.57 & 0.46 \\
\hline \multicolumn{2}{|l|}{ Washington DC } & 0.57 & 0.57 & 0.57 & 0.57 & 0.46 \\
\hline \multicolumn{2}{|l|}{ Los Angeles } & 1.22 & 1.22 & 1.22 & 1.22 & 1.22 \\
\hline \multicolumn{2}{|l|}{ Houston } & 1.22 & 1.22 & 1.22 & 1.22 & 1.22 \\
\hline \multicolumn{2}{|l|}{ Phoenix } & 1.22 & 1.22 & 1.22 & 1.22 & 1.22 \\
\hline
\end{tabular}


Table 6

California Title-24 2005 Prescriptive Window Properties (from Table 143-A)

\begin{tabular}{llllllr}
\hline Window-to-wall ratio (WWR): & $0-10$ & $11-20$ & $21-30$ & $31-40$ & $\begin{array}{r}\text { U-factor } \\
\text { Atu/h- }{ }^{2}{ }^{\circ} \mathrm{F}\end{array}$ \\
\hline \multicolumn{2}{l}{ Assembly maximum SHGC: } & & & & & 0.47 \\
Climates 1,16 & Non-north & 0.49 & 0.43 & 0.43 & 0.43 & \\
& North & 0.72 & 0.49 & 0.47 & 0.47 & 0.77 \\
Climates 3-5 & Non-north & 0.61 & 0.55 & 0.41 & 0.41 & \\
& North & 0.61 & 0.61 & 0.61 & 0.61 & 0.77 \\
Climates 6-9 & Non-north & 0.61 & 0.61 & 0.39 & 0.34 & \\
& North & 0.61 & 0.61 & 0.61 & 0.61 & 0.47 \\
Climates 14,15-13 & Non-north & 0.47 & 0.36 & 0.36 & 0.31 & \\
& North & 0.61 & 0.51 & 0.47 & 0.47 & 0.47 \\
& Non-north & 0.46 & 0.36 & 0.36 & 0.31 & \\
\hline
\end{tabular}

A generic electrochromic window based on measured spectral data from various electrochromic prototype devices was modeled. The windows were modeled with bleached and colored (absorptive) solaroptical properties given in Table 4 . The window was modeled to switch linearly over a continuous infinite range between bleached and colored states. The exterior 6-mm EC glazing had an emissivity of 0.84 on the exterior surface and 0.15 on the interior. The EC glazing was combined with a $0.6-\mathrm{cm}(0.25$-in.) interior clear glazing layer with a $1.27-\mathrm{cm}(0.5-i n$.) wide air gap. For the various window areas modeled, the window was assumed to be a single lite with no intermediate framing members (Figure 4). The electrochromic window was switched so as to provide 538 lux (50 fc) at $3.05 \mathrm{~m} \mathrm{(10} \mathrm{ft)} \mathrm{from} \mathrm{the} \mathrm{window}$ wall, centered on the window, and at a work plane height of $0.76 \mathrm{~m}(2.5 \mathrm{ft})$ every hour during daylight hours. If there was insufficient daylight, the window was switched to fully bleached. If there was too much daylight, the window was switched to fully colored. This strategy is called "daylight control" and is best used to minimize cooling loads and lighting energy use.

\subsection{Interior Shade}

The base case windows were modeled with and without an interior shade. The shade was "manually" operated where the shade was either fully up or drawn down completely by the occupant during daylight hours if direct sun or glare was present. The shade was deployed if the heat gain per square foot of window area from direct (beam) solar radiation transmitted through the window exceeded $94.57 \mathrm{~W} / \mathrm{m}^{2}$ (30 Btu/h$\mathrm{ft}^{2}$ ) or if the daylighting glare index computed using the Hopkinson Cornell-BRS formula exceeded 22 ("just uncomfortable", maximum recommended for general office work). With the shade drawn, the visible transmittance of the glazing is reduced by $65 \%$ and the solar heat gains by $40 \%$ (translucent light white drape).

The shade was modeled as a planar, ideally diffuse, translucent layer parallel to the glass layers and interior to the window. The effectiveness of shading systems to moderate heat flux through fenestration systems varies with the type of window it is combined with, solar incident angle, and other factors. However, the present state of available measured data on shading devices does not permit greater accuracy in the calculation of heat flow through shaded fenestration and prior measurements predate modern developments in fenestration systems. Also, the shade algorithms in the DOE-2.1E program do not facilitate the modification of angle-dependent solar-optical properties or the inward-flowing fraction to enable one to conduct a detailed separation of transmitted and absorbed fluxes and the distribution of absorbed energy among multiple fenestration layers. Therefore, the shade modeled in DOE-2.1E represents at best an approximation. Note, however that the solar heat gain multiplier used has been applied to the solar heat flux at the appropriate angle of incidence, as is standard in DOE-2.1E.

\subsection{Exterior Window Obstructions}

Fins and overhangs were modeled in DOE-2.1E as opaque, non-reflective surfaces. These obstructions block diffuse light from the sky and direct sun but reflect no light from the ground. Two overhang depths were modeled (Table 7 and Figure 4). The width of the overhang was made the same width as the office module: $3.05 \mathrm{~m}(10 \mathrm{ft})$. The overhang height was set so that its lower surface was flush with the top of the 
framed window opening. A single case was modeled for fins (Table 8 and Figure 4). The fin depth yields an azimuthal cut-off angle of $26.6^{\circ}$ for shading the full window width (" $100 \%$-shade" condition) and $45^{\circ}$ for shading half the window width (" $50 \%$-shade" condition). The fin was made the full height of the window and placed flush with the left and right edges of the framed window opening. When the overhang and fins were combined, the overhang width was the width of the window.

A setback condition was modeled where the window was recessed from the exterior plane of the façade, so that a $0.30 \mathrm{~m}$ (1-ft) deep overhang, fin and sill shade the glazing.

Exterior building obstructions were modeled as a $16.5-\mathrm{m}$ or $30.78-\mathrm{m}$ (54.14-ft or $101-\mathrm{ft}$ ) high opaque

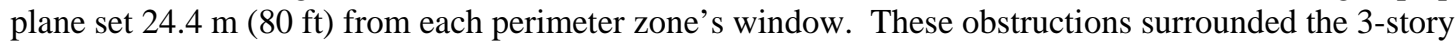
modeled building entirely on all four sides and were effectively of infinite length. The heights of the exterior obstructions were calculated to yield profile angles of $22.5^{\circ}$ or $45^{\circ}$ from the second floor window head so that the window was fully shaded when solar profile angles were less than $22.5^{\circ}$ or $45^{\circ}$. The exterior obstruction was modeled with a visible surface reflectance of 0.50 and had a luminance due to the light from the sky and ground. The ground had a surface reflectance of 0.20 . The profile angles of the obstructions at each floor are given in Table 9 and shown in Figure 5.

Table 7

Overhang Depths (ft)

\begin{tabular}{lrrrrr}
\hline \multicolumn{5}{c}{ Profile Window-to-wall ratio: } \\
& Angle $\left(^{\circ}\right)$ & 0.15 & 0.30 & 0.45 & 0.60 \\
\hline Case A & 65 & 2.10 & 2.80 & 2.80 & 3.36 \\
Case B & 55 & 3.15 & 4.20 & 4.20 & 5.04 \\
\hline
\end{tabular}

Table 8

Fin Depths (ft)

Window-to-

$\begin{array}{llll}\text { Wall Ratio: } \quad 0.15 & 0.30 & 0.45 & 0.60\end{array}$

Window width: $\quad 4.00 \quad 6.00 \quad 4.50 \quad 5.00$

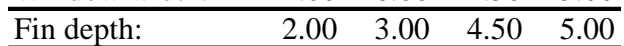

Table 9

Profile angle (degrees) of exterior obstructions

\begin{tabular}{lrrr}
\hline Floor: & 1st & 2nd & 3rd \\
\hline Case 22.5 & 14.8 & 22.5 & 29.1 \\
Case $45^{\circ}$ & 40.0 & 45.0 & 49.0 \\
\hline
\end{tabular}

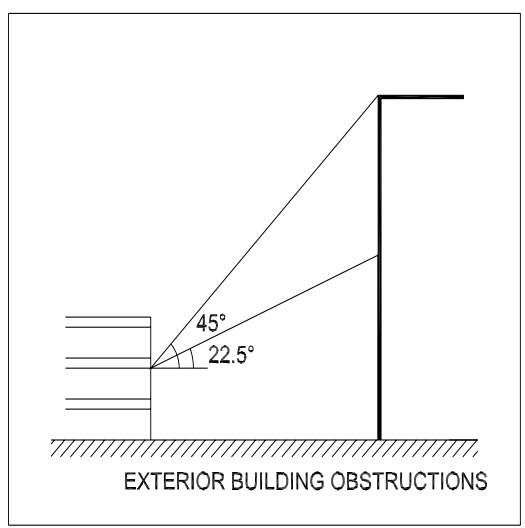

Fig. 5. Profile angle of exterior horizon obstructions as seen by the second floor window. 


\subsection{Lighting}

Recessed fluorescent lighting systems were modeled with a lighting power density of $12.9 \mathrm{~W} / \mathrm{m}^{2}(1.2$ $\mathrm{W} / \mathrm{ft}^{2}$ ) throughout the building. Heat from the lighting system was apportioned to the interior space (60\%) and to the unconditioned plenum (40\%). If no daylighting controls were specified, the lighting was assumed to be at $100 \%$ power, and governed, as in the daylighting case, by the occupancy schedule.

If daylighting controls were specified, the perimeter zone electric lights were dimmed linearly (continuous dimming) so as to provide 538 lux (50 fc) at $3.05 \mathrm{~m} \mathrm{(10} \mathrm{ft)} \mathrm{from} \mathrm{the} \mathrm{window} \mathrm{wall,} \mathrm{centered} \mathrm{on}$ the window, and at a work plane height of $0.76 \mathrm{~m}(2.5 \mathrm{ft})$. The electronic dimmable ballasts were modeled with a minimum power consumption of $33 \%$ and $10 \%$ minimum light output. Surface reflectances were $70 \%$ for ceilings, $50 \%$ for walls, and $20 \%$ for floors.

\subsection{Mechanical System}

Five variable-air-volume systems with economizers were employed: one each for perimeter zones facing a particular orientation (i.e., north-facing perimeter zones on all three floors were controlled by one system) and one for the three core zones. Such zoning facilitated an analysis of window orientation on heating and cooling energy use. The heating thermostat setpoint was $21.1^{\circ} \mathrm{C}\left(70^{\circ} \mathrm{F}\right)$ during occupied hours with a night setback temperature of $12.8^{\circ} \mathrm{C}\left(55^{\circ} \mathrm{F}\right)$; the cooling thermostat setpoint was $23.9^{\circ} \mathrm{C}\left(75^{\circ} \mathrm{F}\right)$ with a night setback temperature of $37.2^{\circ} \mathrm{C}\left(99^{\circ} \mathrm{F}\right)$. Heating was provided by a gas boiler and cooling was provided by a hermetic centrifugal chiller and cooling tower.

\subsection{Annual Total Energy Use and Peak Demand}

All perimeter zone performance data are given per unit floor area. Perimeter zone annual cooling electricity use was determined using system-level extraction loads converted to plant-level electricity use with a fixed coefficient of performance (COP) of 3.0. This was added to the perimeter zone annual electricity use data (includes lighting, convenience outlets, and supply and return fans for heating, heating and cooling, and float periods) to arrive at total annual electricity use. Peak electricity demand was determined in a similar manner. Demand data are given for the peak condition that occurs in each perimeter zone and are non-coincident with the whole building's peak condition.

Perimeter zone annual heating energy use was determined using system-level extraction loads converted to plant-level energy use with a fixed heating efficiency factor (HEF) of 0.8. Fan electric energy use for hours when only heating is required was not added to this quantity to enable total energy performance comparisons based on fuel type.

In order to determine total annual energy use (heating + electricity), a site-to-source efficiency of 3.0 was used for electricity and 1.0 was used for natural gas. The site-to-source efficiency indicates the generating efficiency of the fuel or utility prior to its use in the simulated building.

DOE-2 was allowed to automatically size the plant equipment for each parametric run to ensure realistic part-load-ratio operations. The COP and HEF efficiency factors represent system-to-plant efficiency, not component-level equipment efficiencies such as those given in ASHRAE 90.1. Such a procedure was necessary since the DOE-2.1E program does not separate zonal energy at the plant level. These perimeter zone data enable equitable comparisons to be made across the entire dataset.

\subsection{Energy and Peak Demand Savings}

Annual total energy use and peak demand savings were determined by comparing the performance of the EC window to the performance of the prescribed windows defined by the energy codes and state-of-theart commercially-available windows. In a retrofit situation, it is implicitly assumed that replacement would occur in any case. Therefore, the comparison is not based on the performance of the existing window system destined to be replaced, but on the technology most likely to be used today. Several base case scenarios were defined:

- Windows that met CEC Title 24-2005 or ASHRAE 90.1-1999 Standards. Base case windows were modeled without interior shades or daylighting controls. EC windows were modeled without interior 
shades and with daylighting controls. ASHRAE and Title-24 prescriptive energy budgets are given in Table 10.

- State-of-the-art windows were defined as a spectrally-selective low-e tinted window (type F).

- State-of-the-art window (F) with attached exterior shades: fins for north-facing windows, overhangs (case B) and fins for the east- and west-facing windows, and overhangs (case A) for south-facing windows. EC window modeled without attached exterior shades.

- State-of-the-art window (F) in a built-up metropolitan area (22.5 exterior horizon obstruction). EC window was modeled with horizon obstructions.

In the latter three base case types, base case windows were modeled with and without interior shades and with and without daylighting controls. EC windows were modeled without interior shades and with and without daylighting controls.

\subsection{Impact Assessment Method}

For competitive solicitations and to track progress toward programmatic goals, public agencies such as DOE and the California Energy Commission (CEC) have their own methods of determining the savings in primary energy consumption resulting from technology changes in buildings. The Government Performance and Results Act (GPRA) Metrics [20] are used to estimate fiscal year energy, environmental, and financial benefits of technologies in the US DOE Office of Building Technology, State and Community Programs (BTS) within the DOE's Office of Energy Efficiency and Renewable Energy (EERE). For the fiscal year 2004 (FY04) evaluation, electrochromic windows were modeled using a simple adjustment to the shell index. For the FY05 evaluation, a computerized estimation tool was used to model the heating, cooling, and lighting load changes by building type and climate region (north and south). The CEC Database for Energy Efficient Resources (DEER) [21] provides estimates of average cost, market saturation, and energy-savings potential for base case and more energy-efficient measures. Other R\&D groups provide independent analysis of not only primary energy-savings potential but ranking of technologies based on energy and peak demand savings, cost of saved energy (based on the levelized cost of a measure over its lifetime per unit of energy saved), and likelihood of success [22].

Compared to other energy-efficiency technologies, emerging window technologies for commercial buildings have a unique blend of issues that complicates an assessment of potential impact. Energy savings are dependent on climate, window orientation and size, and type of supporting building systems (HVAC, lighting, etc.). Window technologies affect space cooling, space heating, lighting, and ventilation end uses and therefore both heating and electricity fuel types. Primary energy use databases such as EIA's CBECS [23] do not have sufficient detail that would enable one to map these various parameters to energy-savings potential with a relatively straightforward calculation.

Therefore, a simpler assessment method has been used in this study to determine the impact of EC window and daylighting systems on US primary energy use. Site energy savings was multiplied by a volume of glazing sales and by percentage market penetration. The volume and growth rate of glazing sales were estimated by PNNL using data from the DOE 2003 Building Energy Data Book and CBECS data [24]. The percentage market penetration was estimated by PNNL using input from DOE and industry [25]. Using data from this study, energy savings were computed for each fuel type and for the six climates. An average national energy savings by fuel type was then computed by weighting the energy savings for each US climate by the percentage of commercial building floor area for each climate zone (derived from CBECS 1999 data). Primary energy savings were computed using a site-to-source electricity conversion of 3.0.

Statewide impact on the California primary energy use was not determined. CEC is in the process of developing a method to evaluate potential energy impacts of public interest Public Interest Energy Research (PIER) Program [26]. Discussions with the developer indicated that their model would not be able to accommodate the complex effects of windows on primary energy use because of insufficient resolution of the energy database [27]. PNNL noted that the PG\&E Commercial End-Use Survey database [28] has potentially sufficient information to determine the impact of EC windows in some portion of Northern California, but a detailed analysis of this database and derivation of a method using this database was outside the scope of this work. 
Table 10

ASHRAE 90.1-1999 and CEC Title-24-2005 Standards Prescriptive Energy Budgets

\begin{tabular}{|c|c|c|c|c|c|c|c|c|c|}
\hline \multicolumn{6}{|c|}{ Primary Total Annual Energy Use (kBtu/ft²-floor-year) } & \multicolumn{4}{|c|}{ Site Peak Demand (W/ $\mathrm{ft}^{2}$-floor) } \\
\hline Climate & WWR & $\begin{array}{c}\text { North } \\
\text { Zone }\end{array}$ & $\begin{array}{l}\text { East } \\
\text { Zone }\end{array}$ & $\begin{array}{r}\text { South } \\
\text { Zone }\end{array}$ & $\begin{array}{l}\text { West } \\
\text { Zone } \\
\end{array}$ & $\begin{array}{l}\text { North } \\
\text { Zone } \\
\end{array}$ & $\begin{array}{l}\text { East } \\
\text { Zone } \\
\end{array}$ & $\begin{array}{l}\text { South } \\
\text { Zone } \\
\end{array}$ & $\begin{array}{l}\text { West } \\
\text { Zone } \\
\end{array}$ \\
\hline \multicolumn{10}{|c|}{ National climate zones: } \\
\hline Minneap & 0.15 & 128.2 & 138.8 & 137.6 & 136.3 & 3.47 & 4.22 & 4.26 & 3.99 \\
\hline Minneap & 0.30 & 140.4 & 159.1 & 156.8 & 156.3 & 3.86 & 5.26 & 5.19 & 4.92 \\
\hline Minneap & 0.45 & 149.3 & 161.6 & 158.9 & 159.0 & 4.26 & 5.25 & 5.17 & 4.93 \\
\hline Chicago & 0.15 & 125.6 & 134.9 & 134.2 & 134.1 & 3.53 & 4.16 & 4.08 & 4.10 \\
\hline Chicago & 0.30 & 136.2 & 153.1 & 151.3 & 151.8 & 3.94 & 5.17 & 5.04 & 5.05 \\
\hline Chicago & 0.45 & 139.6 & 155.0 & 152.2 & 154.1 & 4.04 & 5.16 & 5.00 & 5.02 \\
\hline WashDC & 0.15 & 128.0 & 50.3 & 41.4 & 99.6 & 3.58 & 4.27 & 4.45 & 4.27 \\
\hline WashDC & 0.30 & 128.0 & 137.1 & 138.1 & 136.4 & 3.66 & 4.27 & 4.45 & 4.27 \\
\hline WashDC & 0.45 & 137.2 & 152.9 & 154.2 & 152.5 & 4.10 & 5.34 & 5.57 & 5.36 \\
\hline Atlanta & 0.15 & 139.6 & 152.3 & 152.4 & 152.0 & 4.19 & 5.20 & 5.34 & 5.18 \\
\hline Atlanta & 0.30 & 136.4 & 50.5 & 57.9 & 102.6 & 4.00 & 5.39 & 5.39 & 5.45 \\
\hline Atlanta & 0.45 & 139.3 & 51.7 & 58.7 & 103.6 & 4.04 & 5.45 & 5.29 & 5.46 \\
\hline Houston & 0.15 & 141.7 & 143.0 & 144.2 & 143.1 & 4.00 & 4.06 & 4.18 & 4.10 \\
\hline Houston & 0.30 & 152.0 & 152.2 & 152.5 & 152.5 & 4.60 & 4.83 & 4.96 & 4.90 \\
\hline Houston & 0.45 & 155.0 & 154.4 & 153.5 & 155.6 & 4.77 & 4.93 & 4.94 & 5.09 \\
\hline Phoenix & 0.15 & 148.1 & 156.0 & 158.6 & 154.9 & 4.46 & 4.72 & 4.78 & 4.81 \\
\hline Phoenix & 0.30 & 161.7 & 170.6 & 171.2 & 170.5 & 5.40 & 5.87 & 5.74 & 6.21 \\
\hline Phoenix & 0.45 & 168.2 & 174.3 & 173.1 & 176.2 & 5.85 & 6.17 & 6.05 & 6.62 \\
\hline \multicolumn{10}{|c|}{ California climate zones: } \\
\hline CTZ01 & 0.15 & 118.7 & 126.3 & 132.5 & 128.1 & 3.08 & 3.82 & 4.08 & 3.95 \\
\hline CTZ01 & 0.30 & 118.7 & 133.3 & 144.2 & 137.3 & 3.29 & 4.68 & 4.97 & 4.82 \\
\hline CTZ02 & 0.15 & 129.2 & 139.2 & 144.0 & 138.8 & 3.39 & 4.03 & 4.42 & 4.14 \\
\hline CTZ02 & 0.30 & 131.9 & 149.0 & 156.1 & 148.9 & 3.70 & 4.92 & 5.31 & 5.07 \\
\hline CTZ03 & 0.15 & 123.7 & 137.7 & 145.2 & 138.8 & 3.23 & 4.24 & 4.59 & 4.34 \\
\hline CTZ03 & 0.30 & 125.2 & 139.9 & 149.5 & 142.2 & 3.33 & 4.79 & 5.24 & 4.97 \\
\hline CTZ04 & 0.15 & 126.4 & 141.0 & 147.8 & 141.4 & 3.51 & 4.63 & 4.69 & 4.56 \\
\hline CTZ04 & 0.30 & 129.2 & 145.3 & 152.6 & 146.0 & 3.73 & 5.32 & 5.30 & 5.14 \\
\hline CTZ05 & 0.15 & 123.9 & 136.8 & 145.2 & 139.0 & 3.43 & 4.42 & 4.75 & 4.56 \\
\hline CTZ05 & 0.30 & 126.4 & 140.8 & 150.7 & 143.8 & 3.65 & 5.02 & 5.32 & 5.17 \\
\hline CTZ06 & 0.15 & 132.6 & 148.8 & 158.5 & 152.6 & 3.51 & 4.61 & 5.01 & 4.79 \\
\hline CTZ06 & 0.30 & 136.7 & 147.7 & 158.4 & 152.9 & 3.65 & 4.93 & 5.45 & 5.15 \\
\hline CTZ07 & 0.15 & 134.8 & 148.8 & 158.8 & 152.7 & 3.54 & 4.53 & 5.08 & 4.84 \\
\hline CTZ07 & 0.30 & 136.2 & 145.1 & 156.0 & 150.0 & 3.82 & 5.02 & 5.41 & 5.23 \\
\hline CTZ08 & 0.15 & 132.0 & 148.9 & 158.9 & 151.9 & 3.44 & 4.62 & 5.06 & 4.86 \\
\hline CTZ08 & 0.30 & 136.0 & 147.9 & 159.1 & 152.1 & 3.62 & 4.97 & 5.48 & 5.19 \\
\hline CTZ09 & 0.15 & 132.7 & 152.2 & 160.8 & 153.2 & 3.55 & 4.95 & 5.91 & 5.02 \\
\hline CTZ09 & 0.30 & 137.2 & 150.6 & 161.0 & 152.2 & 3.76 & 5.32 & 6.13 & 5.29 \\
\hline CTZ10 & 0.15 & 134.9 & 143.4 & 150.1 & 144.0 & 3.49 & 4.07 & 4.53 & 4.21 \\
\hline CTZ10 & 0.30 & 138.1 & 152.0 & 162.3 & 153.6 & 3.81 & 4.98 & 5.63 & 5.25 \\
\hline CTZ11 & 0.15 & 133.5 & 144.6 & 147.6 & 144.0 & 3.67 & 4.47 & 4.48 & 4.58 \\
\hline CTZ11 & 0.30 & 138.8 & 158.7 & 161.9 & 157.9 & 4.16 & 5.68 & 5.70 & 5.87 \\
\hline CTZ12 & 0.15 & 130.9 & 142.1 & 145.5 & 141.2 & 3.47 & 4.16 & 4.29 & 4.23 \\
\hline CTZ12 & 0.30 & 134.1 & 153.7 & 157.6 & 152.7 & 3.82 & 5.12 & 5.27 & 5.34 \\
\hline CTZ13 & 0.15 & 134.5 & 147.4 & 150.4 & 147.4 & 3.56 & 4.36 & 4.41 & 4.54 \\
\hline CTZ13 & 0.30 & 139.5 & 160.5 & 162.7 & 160.4 & 3.93 & 5.51 & 5.54 & 5.77 \\
\hline CTZ14 & 0.15 & 137.7 & 151.6 & 155.5 & 150.4 & 3.66 & 4.53 & 4.51 & 4.68 \\
\hline CTZ14 & 0.30 & 143.5 & 165.8 & 169.8 & 164.0 & 4.12 & 5.76 & 5.71 & 5.96 \\
\hline CTZ15 & 0.15 & 145.9 & 159.8 & 165.9 & 159.7 & 3.80 & 4.58 & 4.80 & 4.78 \\
\hline CTZ15 & 0.30 & 153.1 & 174.5 & 180.8 & 173.0 & 4.32 & 5.86 & 6.26 & 6.10 \\
\hline CTZ16 & 0.15 & 122.9 & 138.1 & 140.8 & 136.6 & 3.47 & 4.59 & 4.68 & 4.53 \\
\hline CTZ16 & 0.30 & 127.1 & 154.8 & 158.1 & 153.2 & 3.86 & 5.91 & 6.07 & 5.95 \\
\hline
\end{tabular}

Note: For ASHRAE 90.1, the energy budget for WWR=0.60 is the same as that for WWR=0.45. For CEC Title-24, the energy budgets for WWR=0.45 and 0.60 is the same as that for WWR=0.30. 


\section{Results}

\subsection{Perimeter Zone Primary Energy and Peak Demand Savings}

Differences (kBtu and $\mathrm{W} / \mathrm{sf}$ ) and percentage differences in primary annual energy use (electricity and heating energy use combined) and peak electricity demand for the prototypical three-story commercial office building are summarized below for all 22 climates and the various base case scenarios. Data are given for WWR $=0.30$ and WWR $=0.60$ in Tables 11-42. South zone total primary energy use and peak electricity demand are given for Chicago, Houston, and California climate zones 2, 9, 12, and 14 in Figures 6-11. Due to large number of figures and tables associated with this dataset, Figures 6-11 and Tables 11-42 are given at the end of this paper. This report does not explain trends in lighting and cooling energy use with respect to window area, orientation, and climate. These trends are explained in prior DOE-2 simulation reports on EC windows (cited earlier [2-7]).

Compared to ASHRAE 90.1-1999 and California Title 24-2005 energy standards (prescribed SHGC and U-value with no daylighting controls or shades), EC windows with no shades and with daylighting controls reduce energy and peak demand significantly in most climates (Tables 11-18):

Small windows (WWR=0.30):

- $15-28 \%$ energy savings in all climates

- $10-25 \%$ peak demand reductions in most climates

Large windows (WWR=0.60):

- $10-24 \%$ energy savings in most climates

- $10-15 \%$ peak demand reductions in most climates

- $0-5 \%$ increased peak demand in some hot US climates and some California climates (not correlated to climate)

Compared to spectrally-selective low-e windows (type F) with daylighting controls and no shades, EC windows with daylighting controls and no shades reduce energy and peak demand significantly for large windows in east, west, and south zones in most climates (Tables 19-26):

Small windows (WWR=0.30):

- $\quad \pm 5 \%$ energy savings in east, west, and north zones in most climates

- $5-9 \%$ energy savings in south zones in some climates

- $0-5 \%$ increased peak demand in north zones in most climates

- $\quad 5-10 \%$ peak demand savings in east and west zones in most climates

- $\quad 10-15 \%$ peak demand savings in south zones in most climates

Large windows (WWR $=0.60)$ :

- $\quad \sim$ same energy use in north zones in most climates

- $10-15 \%$ energy savings in east and west zones in most climates

- $\quad 15-20 \%$ energy savings in south zones in most climates

- $\quad 0-5 \%$ peak demand reductions in north zones in California climates

- $\quad 20-25 \%$ peak demand reductions in east, west, and south zones in most climates

Compared to spectrally-selective low-e windows (type F) with daylighting controls, with no interior shades, and with attached exterior shades (overhangs and/or fins, depending on window orientation - see Section 2.8), EC windows with daylighting controls and without shading yield insignificant reductions in energy and peak demand in most climates (Tables 27-34):

Small windows (WWR $=0.30$ ):

- $\quad 0-5 \%$ increased energy use in all zones in most climates

- $\quad 0-15 \%$ increased peak demand in east, west, and north zones in most climates

- $\quad 8-9 \%$ peak demand reductions in south zones in Washington DC and California climate zone 9

Large windows (WWR=0.60):

- $\quad 0-10 \%$ increased energy use in east, west, and north zones in most climates

- $\quad 5-10 \%$ energy savings in south zones in Washington DC and California climate zones 1-3 
- $\quad 5-15 \%$ increased peak demand in east, west, and north zones in most climates

- $5-18 \%$ peak demand reductions in south zones in a few climates

Compared to spectrally-selective low-e windows (type F) with daylighting controls, no window shades, and with a $22.5^{\circ}$ horizon obstruction (such as opposing buildings or mountains), EC windows with daylighting controls and with the same horizon obstructions yield significant reductions in energy and peak demand for large windows in east, west, and south zones in most climates (Tables 35-42):

Small windows (WWR=0.30):

- $0-5 \%$ increased energy use in east, west, and north zones in most climates

- $5-8 \%$ energy savings in south zones in a few climates

- $\quad \pm 5 \%$ peak demand in east, west, and south zones in most climates

- $5-15 \%$ peak demand reductions in south zones in a few climates

Large windows (WWR=0.60):

- $0-5 \%$ increased energy use in north zones in all climates

- $\quad 5-13 \%$ energy savings in east and west zones in all climates

- $10-17 \%$ energy savings in south zones in most climates

- $0-5 \%$ increased peak demand in north zones in most climates

- $15-25 \%$ peak demand reductions in south zones in most climates

- $15-20 \%$ peak demand reductions in east and west in most climates

\subsection{US Primary Energy Savings}

Table 43 gives the site (includes all four perimeter zones and core zone) electric and natural gas savings for six US climates for two different base cases with no exterior obstructions: 1) spectrallyselective low-E windows with no shades and no daylighting controls and 2) spectrally-selective low-E windows with " $50 \%$-deployed" manual interior white shades and no daylighting controls. The first case gives energy savings relative to conventional practice where the best available static window is used today without daylighting controls. The second case gives energy savings relative to static windows with " $50 \%$ deployed" manual interior shades, which is defined as the average energy use between the no-shade case and the case with interior shades. The interior shade case represents optimal shade control by a user for every hour of the year, which is unsupported by field data. Therefore, a halfway point between the no shade and shade case was used to represent more realistic energy use with conventional windows. Most analysts would like to evaluate the EC window without daylighting controls. However, the EC window was controlled to optimize daylight levels in this analysis and therefore yield optimum zonal energy use. If the technical potential of the EC window is to be evaluated solely on space conditioning use impacts, then it should be controlled to minimize space conditioning energy use (cooling in the summer and heating in the winter).

The market penetration rates for new and existing construction are given in Figure 12. The volume and growth rate of glazing sales are given in Figure 13. Primary energy savings for each of the two base case scenarios are given in Figure 14 assuming an average window-to-wall ratio of 0.30. The 2003 Energy Databook [29] indicates that for a typical large office building, the percentage of glass is typically $40-50 \%$ and for small office buildings, it is typically $15-20 \%$. Note that these primary energy savings assume that the savings that are applicable to all commercial building types. EC systems are generally applicable to buildings types with perimeter windows such as offices, schools, some mercantile and service buildings, and some health care facilities or $47 \%$ of the total primary commercial energy consumption (and possibly other building types). These systems are less applicable to lodging, warehouse and storage buildings. If one assumes $50 \%$ of total commercial building floor space is applicable, then the total US primary energy savings potential of EC windows and daylighting systems is $97.3 \mathrm{TBtu}\left(1 \mathrm{TBtu}=10^{12} \mathrm{Btu}\right)$ for the no shade case and 91.5 TBtu for the 50\%-shade case in 2030. This number is in close agreement with the FY04 GPRA estimate of 102.5 TBtu or 0.102 quads ( 1 quad $=10^{15}$ Btu). Using carbon emission factors of 15.67 $\mathrm{kg} / \mathrm{MMBtu}$ for electricity and $14.40 \mathrm{~kg} / \mathrm{MMBtu}$ for gas, total carbon savings are $1.55 \times 10^{6}$ metric tons $\mathrm{C}$ for the no shade case and $1.41 \times 10^{6}$ metric tons $C$ for the $50 \%$ shade case in 2030 . These energy savings would equate to a monetary savings in 2030 of $\$ 670-713$ million (1 quad $=\$ 7330$ million).

EC window systems produce other benefits including reductions in peak energy loads, enhanced reliability of the utility grid, enhanced security due to reduced oil demand, and increased comfort in 
buildings. These have not been evaluated. Peak demand reductions were not aggregated between the four perimeter zones and core zone for this analysis since the peak loads were non-coincident. Peak demand reductions at the whole building level would have required that the HVAC capacity to be sized the same between the base case and EC case, which was outside the scope of this work. Refer to peak demand reductions given in Section 3.1 for perimeter zones.
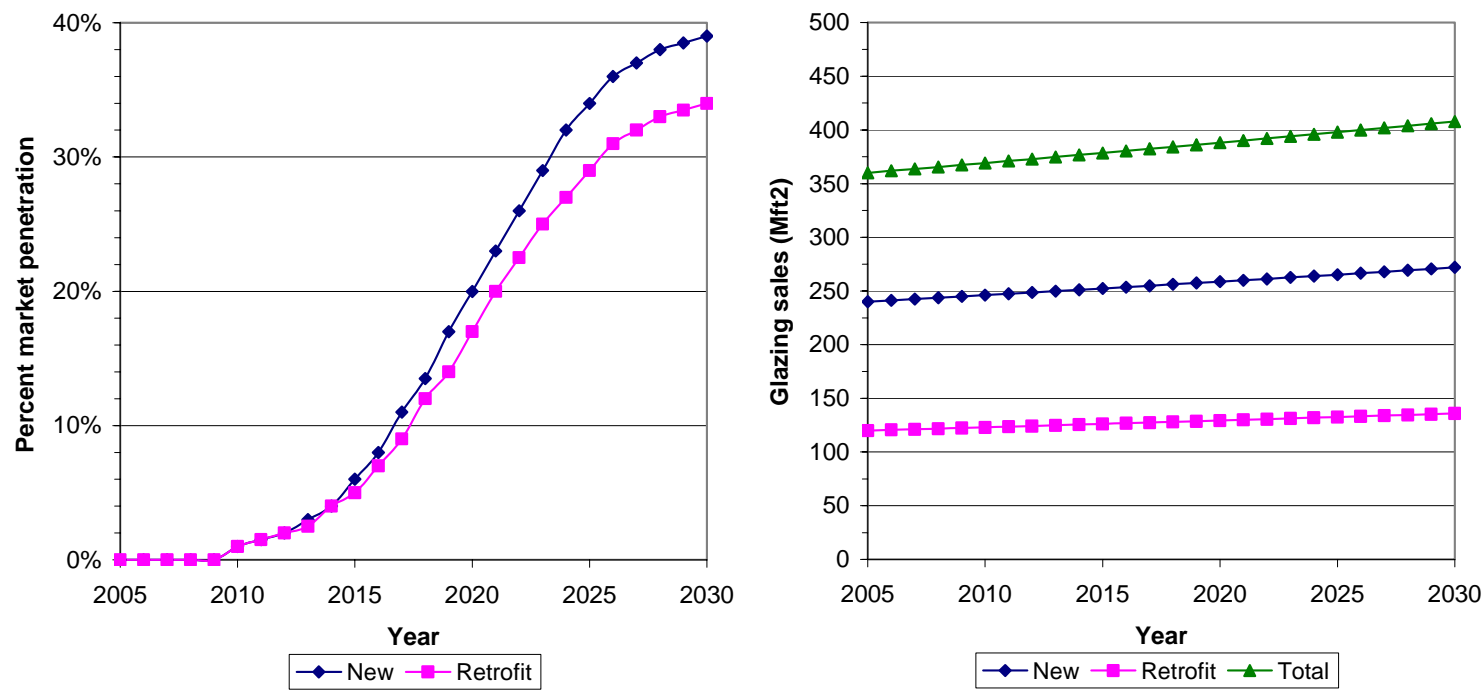

Fig. 12. Market penetration rates of electrochromic windows for new and existing construction.

Fig. 13. The volume and growth rate of glazing sales.

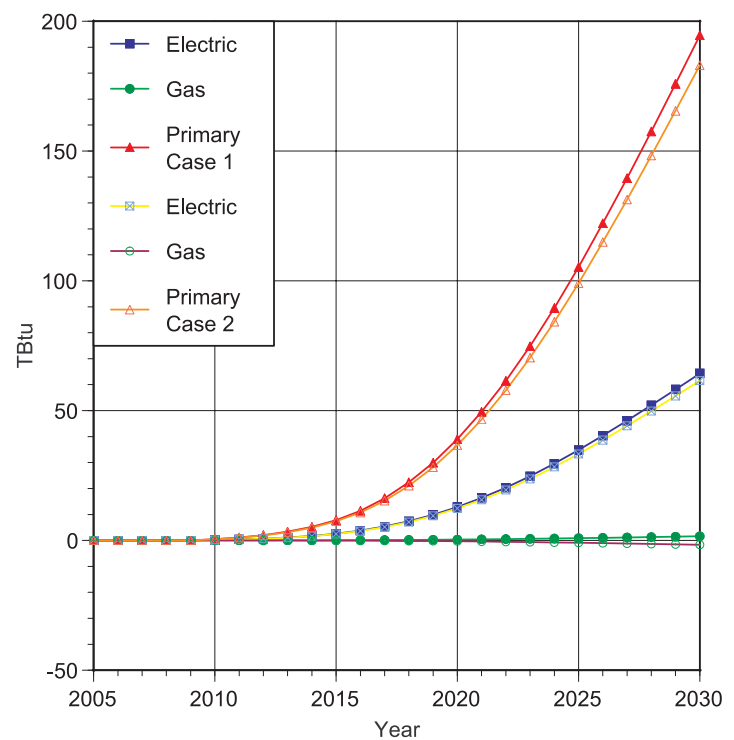

Fig. 14. Primary energy savings (TBtu) for each of the two base case scenarios (WWR=0.30). If $50 \%$ of total commercial building floor space is applicable, then the total US primary energy savings potential would be half of the values shown on this graph. 
Table 43

\begin{tabular}{|c|c|c|c|c|c|c|}
\hline \multicolumn{7}{|c|}{ Site annual electricity use and natural gas use savings ( $\mathrm{kBtu} / \mathrm{ft}^{2}$-window-yr) } \\
\hline Location & WWR & $\begin{array}{c}\text { Window } \\
\text { Type }\end{array}$ & $\begin{array}{r}\text { Case } 1 \\
\text { Electric }\end{array}$ & $\begin{array}{r}\text { Case } 1 \\
\text { Gas } \\
\end{array}$ & $\begin{array}{r}\text { Case } 2 \\
\text { Electric }\end{array}$ & $\begin{array}{r}\text { Case } 2 \\
\text { Gas } \\
\end{array}$ \\
\hline Minneap & 0.15 & G & 49.22 & -4.18 & 46.78 & -5.89 \\
\hline Minneap & 0.30 & G & 41.75 & -0.45 & 38.99 & -3.85 \\
\hline Minneap & 0.45 & G & 37.57 & 2.25 & 34.21 & -2.31 \\
\hline Minneap & 0.60 & G & 34.62 & 4.82 & 30.67 & -0.87 \\
\hline Chicago & 0.15 & G & 49.63 & -2.12 & 47.51 & -3.83 \\
\hline Chicago & 0.30 & G & 41.56 & 0.49 & 39.21 & -2.43 \\
\hline Chicago & 0.45 & G & 36.56 & 1.81 & 33.65 & -2.17 \\
\hline Chicago & 0.60 & G & 32.96 & 3.09 & 29.61 & -1.68 \\
\hline WashDC & 0.15 & G & 51.80 & -0.52 & 49.73 & -2.15 \\
\hline WashDC & 0.30 & G & 42.89 & 2.13 & 40.51 & -1.00 \\
\hline WashDC & 0.45 & G & 37.75 & 3.80 & 34.73 & -0.36 \\
\hline WashDC & 0.60 & G & 34.21 & 5.40 & 30.59 & -0.03 \\
\hline Atlanta & 0.15 & $\mathrm{~F}$ & 48.65 & -0.16 & 48.05 & -0.49 \\
\hline Atlanta & 0.30 & $\mathrm{~F}$ & 38.36 & 1.33 & 37.62 & 0.44 \\
\hline Atlanta & 0.45 & $\mathrm{~F}$ & 33.22 & 2.56 & 31.65 & 1.20 \\
\hline Atlanta & 0.60 & $\mathrm{~F}$ & 29.52 & 3.40 & 27.51 & 1.52 \\
\hline Houston & 0.15 & $\mathrm{~F}$ & 46.93 & -0.06 & 46.58 & -0.11 \\
\hline Houston & 0.30 & $\mathrm{~F}$ & 36.75 & 0.51 & 36.48 & 0.22 \\
\hline Houston & 0.45 & $\mathrm{~F}$ & 31.19 & 1.31 & 30.34 & 0.46 \\
\hline Houston & 0.60 & $\mathrm{~F}$ & 27.43 & 2.39 & 26.12 & 0.93 \\
\hline Phoenix & 0.15 & $\mathrm{~F}$ & 51.24 & -0.05 & 49.38 & -0.06 \\
\hline Phoenix & 0.30 & $\mathrm{~F}$ & 39.78 & 0.47 & 38.33 & 0.28 \\
\hline Phoenix & 0.45 & $\mathrm{~F}$ & 34.67 & 1.46 & 32.45 & 0.79 \\
\hline Phoenix & 0.60 & $\mathrm{~F}$ & 31.42 & 2.73 & 28.81 & 1.33 \\
\hline All climates* & 0.15 & & 49.78 & -1.08 & 48.19 & -2.14 \\
\hline All climates & 0.30 & & 40.53 & 1.00 & 38.80 & -1.04 \\
\hline All climates & 0.45 & & 35.48 & 2.43 & 33.07 & -0.44 \\
\hline All climates & 0.60 & & 31.95 & 3.78 & 29.05 & 0.06 \\
\hline
\end{tabular}

Notes:

* Data are weighted by CBECS 1999 floor area data given as a function of CBECS climate zones (Houston and Phoenix data were averaged).

Case 1: Base case with no shades and no daylighting controls; EC with

daylighting controls

Case 2: Base case with manual shades and no daylighting controls; EC with daylighting controls 


\section{Discussion}

Technical feasibility of EC windows has been investigated by several independent parties but the details of market barriers remain undisclosed primarily due to the competitive nature of the industry. In 2000, E-Source interviewed various US manufacturers to probe the technical potential of EC materials [30]. Assuming that a large-area switchable window can be produced in volume at low cost, the next step to achieving the full technical potential of EC windows is to integrate these systems with the lighting control system. The feasibility of this concept has been demonstrated in field tests [31]. To reduce wiring costs, low-voltage EC windows have been coupled to a photovoltaic energy source [32], which eases applicability to retrofit markets. Communication costs can be reduced with low-cost networking solutions [33]. For retrofit markets, radio frequency communications show promise. This study assumes that future development work solves technical issues in a way that enables a fully integrated product (window plus daylighting controls) to enter the market at an added incremental cost of \$5-10 per square foot of window by the year 2020 .

Methods used to determine feasibility and market penetration rates vary but most account for the cost of the technology and the customer's method for making purchasing decisions. For example, AD Little estimates commercial viability of various technologies based on field interviews, consumer surveys and market experience, noting that a simple payback of three years or less is needed to achieve technology adoption in a large percentage of the commercial buildings market [34]. Estimates can be based on various product cost models accounting for technology maturation rates, distribution markups, differing utility rate structures (including demand charge savings), regional growth factors, capacity credits, utility rebates, and environmental externality credits for $\mathrm{SO}_{2}, \mathrm{NO}_{x}$, and $\mathrm{CO}_{2}$ reductions. Depending on the class of building ownership, acceptable payback periods vary between two to 10 years - which mandates small incremental costs for new technologies. The technological advances noted in the prior paragraph could help to lower the costs of installation and maintenance. Penetration rates also depend on the ability of products to address key architectural issues and provide occupant amenity. These additional amenities are being studied $[35,36]$. The market penetration rates used in this study are moderately conservative. A survey of US window manufacturers in 2000 indicated that expectations for market penetration of switchable glass products were $6.2 \%$ by 2005 [37]. Figure 15 shows the range in technical potential if other factors such as technological breakthroughs or increased amenity, view, and comfort provide additional incentives to increase the demand of EC windows in the commercial buildings market.

For this emerging technology, the energy-savings cost-benefit argument can best be made in moderate to hot climates where the perimeter zone floor area is large compared to the core zone floor area and the windows are large and unshaded. This analysis uses an EC control algorithm that optimizes solar gain and daylighting trade-offs and therefore optimizes energy efficiency. More work is required to quantify the negative impact glare and direct sun control will have on these energy efficiency projections.

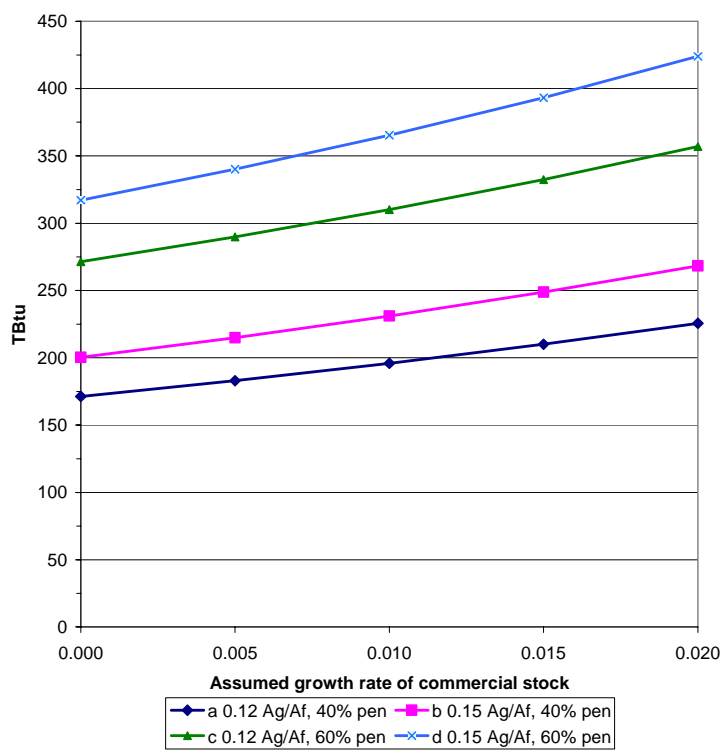

Fig. 15. Primary energy savings in 2030 for case 2 (WWR $=0.30$, base case with $50 \%$ shades and no daylighting controls) for different market penetration rates $(40 \%=$ default, $60 \%$ alternate), different assumed ratios of glazing to floor space (Ag/Af=0.12 is default) and growth rates (0.005 rate is default) in new commercial floor space. If $50 \%$ of total commercial building floor space is applicable, then the total US primary energy savings potential would be half of the values shown on this graph. 


\section{Conclusions}

A DOE-2 computer building energy simulation study was conducted to more thoroughly evaluate the technical potential of electrochromic windows and daylighting systems in a prototypical commercial office building. The performance of EC windows was compared to a wide range of static window types in five US climates and 16 California climate zones. EC performance was also compared to that defined by the ASHRAE 90.1-1999 and California Title 24-2005 Standards. Primary energy savings data were given for each perimeter zone orientation. Site energy savings data were given for whole building electricity use and natural gas use. A rough estimate of US primary energy use savings was given assuming a market introduction in the year 2010 with 40\% market penetration by the year 2030 .

The data confirms findings from earlier simulation studies that indicate that the best technical potential is realized in moderate to hot climates with large area unshaded windows facing east, south, or west.

Significant peak demand reductions are possible, again depending on window orientation, size, and climate. Approximately 0.1 quads of US primary energy use savings are estimated in the year 2030.

\section{Acknowledgments}

We would like to acknowledge David Belzer and James Dirks, Pacific Northwest National Laboratory, for their assistance with the energy impact assessment method, and our LBNL colleagues, Robin Mitchell, Christian Kohler, Mike Rubin, Thomas Richardson, and Jonathon Slack, LBNL, and visiting post-doctoral fellow, Rebecca Powles, for their assistance with Optics5 and EC spectral data.

This work was supported by the California Energy Commission through its Public Interest Energy Research Program and by the Assistant Secretary for Energy Efficiency and Renewable Energy, Office of Building Technology, State and Community Programs, Office of Building Research and Standards of the U.S. Department of Energy under Contract No. DE-AC03-76SF00098.

\section{References}

[1] Building Envelope \& Windows R\&D meeting, Chicago, IL, December 4-6, 2002 held by the US Department of Energy, Office of Energy Efficiency and Renewable Energy's (EERE) Building Technologies Program. http://www.govforums.org/e\&w/

[2] Sullivan R., M. Rubin, and S. Selkowitz. 1997. Energy Performance Analysis of Prototype Electrochromic Windows, ASHRAE Transactions 103(2) (1997): 149-156

[3] Selkowitz, S.E., M. Rubin, E.S. Lee, R. Sullivan. 1994. A Review of Electrochromic Window Performance Factors. Proceedings of SPIE International Symposium on Optical Materials Technology for Energy Efficiency and Solar Energy Conversion, April 1994, Freiburg, Germany.

[4] Sullivan, R., E.S. Lee, K. Papamichael, M. Rubin, S. Selkowitz. 1994. The effect of switching control strategies on the energy performance of electrochromic windows. Proceedings SPIE International Symposium on Optical Materials Technology for Energy Efficiency and Solar Energy Conversion XIII, April 18-22, 1994, Freiburg, Germany.

[5] Lee, E.S. and S. Selkowitz. 1995. "The Design and Evaluation of Integrated Envelope and Lighting Control Strategies for Commercial Building.” ASHRAE Transactions 95 (101)1:326-342.

[6] Karlsson, J. 2001. Control system and energy savings potential for switchable windows. Seventh International IBPSA Conference, Rio de Janeiro, Brazil, August 13-15, 2001.

[7] Gugliermetti, F. and F. Bisegna. 2003. Visual and energy management of electrochromic windows in Mediterranean climates. Building and environment 38(3)(2003):479-492.

[8] Lee, E.S., D. L. DiBartolomeo. 2000. "Application issues for large-area electrochromic windows in commercial buildings.” Solar Energy Materials \& Solar Cells 71 (2002) 465-491. LBNL Report 45841, Lawrence Berkeley National Laboratory, Berkeley, CA.

[9] http://www.iea-shc.org/task27/

[10] http://www.eu-swift.de/

[11] CEC-DOE electrochromic windows field test program: project website: http://windows.lbl.gov/comm_perf/electroSys-cec.htm. 
[12] Winkelmann, F.C, B.E. Birdsall, W.F. Buhl, K.L. Ellington, and A.E. Erdem. 1993. DOE-2 Supplement: Version 2.1E. LBL-34947, Lawrence Berkeley National Laboratory, Berkeley, California.

[13] Winkelmann, F.C. 2001. Modeling Windows in EnergyPlus. Proc. IBPSA, Building Simulation 2001, Rio de Janeiro, September 2001. LBNL-47972, Lawrence Berkeley National Laboratory, Berkeley, California.

[14] Friedrich, M. and M. Messinger. 1995. Method to Assess the Gross Annual Energy-Saving Potential of Energy Conservation Technologies Used in Commercial Buildings. ASHRAE Transactions 1995(101)1: 444-453.

[15] ASHRAE. 1999. ASHRAE/IES Standard 90.1-1999, Energy Efficient Design of New Buildings Except Low-Rise Residential Buildings. Atlanta: American Society of Heating Refrigerating and Air-Conditioning Engineers, Inc.

[16] California Energy Commission Title 24-2001 Energy Efficiency Standards for Nonresidential Buildings and Title 24-2005 (draft as of 2/4/03). http://www.energy.ca.gov/2005_standards/

[17] http://www.bcap-energy.org

[18] ASHRAE. 1989. ANSI/ ASHRAE Standard 62-1989, Ventilation for acceptable indoor air quality. Atlanta: American Society of Heating Refrigerating and Air-Conditioning Engineers, Inc.

[19] CBECS 1999. Commercial Buildings Energy Consumption Survey, Energy Information Administration, EI 301000 Independence Avenue, SW, Washington, DC 20585. http://www.eia.doe.gov/emeu/cbecs/contents.html

[20] Anderson DM, DB Belzer, KA Cort, JA Dirks, DB Elliott, DJ Hostick, and MJ Scott. 2003. Methodological Framework for Analysis of GPRA Metrics: Application to FY04 Projects in BT and WIP. PNNL-14231, Pacific Northwest National Laboratory, Richland, WA.

[21] CEC Database for Energy Efficient Resources (DEER). http://www.energy.ca.gov/deer/index.html

[22] Nadel, S., L. Rainer, M. Shepard, M. Suozzo and J. Thorne. 1998. Emerging Energy-Savings Technologies and Practices for the Buildings Sector. Washington, DC: American Council for an Energy-Efficient Economy.

[23] See [19].

[24] Personal communication with D.B. Belzer, Pacific Northwest National Laboratory, October 8, 2003. The volume of sales in the DOE Data Book was based on AAMA/Ducker Research, Industry Statistical Review and Forecast 1992, 1993 for 1990; and American Architectural Manufacturers Association/Window \& Door Manufacturers Association 2002 Industry Statistical Review and Forecast, March 2003, p. 17 for 2002.

[25] Personal communication with J.A. Dirks, Pacific Northwest National Laboratory, October 9, 2003.

[26] Kintner-Meyer M, DM Anderson, and DJ Hostick. 2003. Final Report for the Energy Efficient and Affordable Small Commercial and Residential Buildings Research Program -- Project 6.6 -

Development of the Assessment Framework. PNNL-14343, Pacific Northwest National Laboratory, Richland, WA. http://www.pnl.gov/main/publications/externalRpt.asp

[27] Personal communication with M. Kintner-Meyer, PNNL May 15, 2003.

[28] PG\&E 1999. Commercial Building Survey Report, with associated datasets from the 1996 Commercial End-Use Survey, Pacific Gas and Electric Company, San Francisco, California, 1999.

[29] Buildings Energy Databook. 2003. Table 5.5.3. US Department of Energy, Office of Energy Efficiency and Renewable Energy. http://buildingsdatabook.eren.doe.gov/

[30] Kinney, L. 2000. Electrochromics: Now you see it; now you don't. ET Currents (4), November 2000. Esource, Boulder, CO.

[31] Lee, E.S., D.L. DiBartolomeo, J.H. Klems, M. Yazdanian, S.E. Selkowitz. 2006. Monitored Energy Performance of Electrochromic Windows Controlled for Daylight and Visual Comfort. To be presented at the ASHRAE 2006 Summer Meeting, Quebec City, Canada, June 24-28, 2006, and published in ASHRAE Transactions. LBNL-58912.

[32] Deb, S. K.; Lee, S.-H.; Tracy, C. E.; Pitts, J. R.; Gregg, B. A.; Branz, H. M. (2001). Stand-Alone Photovoltaic-Powered Electrochromic Smart Window. Electrochimica Acta. Vol. 46(13-14): 21252130.

[33] Lee, E.S., D.L. DiBartolomeo, F.M. Rubinstein, S.E. Selkowitz. 2003. Low-Cost Networking for Dynamic Window Systems. Energy and Buildings 36(6):503-513.

[34] Frantzis, L., D. Friedman, S. Hill, and P. Teagan. 1995. Building-integrated Photovoltaics (VIPV): Analysis and US Market Potential. Report No. 44513, Arthur D. Little, Inc., Cambridge, MA. 
[35] Tenner, A.D. and L. Zonneveldt. 2002. Switchable Facades and Visual comfort. Proceedings of Right Light 5, Nice, France, May 29-31, 2002.

[36] Clear, R.D., V. Inkarojrit, E.S. Lee. 2006. Subject responses to electrochromic windows. To be published in Energy and Buildings, June 2006. LBNL-57125.

[37] Sottile, G.M. 2002. Assessment of attitudes and expectations of switchable glass among United States window manufacturers. Society of Vacuum Coaters, $45^{\text {th }}$ Annual Technical Conference Proceedings (2002): 14-20.

\section{Tables 11-42 and Figures 6-11 are given in the following order:}

\section{Figures 6-11:}

- Fig. 6. Houston South Zone. Annual primary energy use (3:1 fuel ratio) in the perimeter zone of a three-storey commercial office building prototype $\left(\mathrm{kBtu} / \mathrm{ft}^{2}\right.$-year) and peak demand $\left(\mathrm{W} / \mathrm{ft}^{2}\right)$. Cases: ns=no interior shades; $\mathrm{sh}=$ interior shades; $n$ dlc $=$ no daylighting controls; dlc=daylighting controls; all the remaining cases have no interior shades with daylighting controls: setback $=1 \mathrm{ft}$, ov1=overhang case A, ov2=overhang case B, ov2f=overhang case B with fins, 22.5=exterior obstructions with profile angle $22.5^{\circ}, 45=$ exterior obstructions with profile angle $45^{\circ}$.

- Fig. 7. Chicago South Zone.

- Fig. 8. CTZ03 South Zone.

- Fig. 9. CTZ09 South Zone.

- Fig. 10. CTZ12 South Zone.

- Fig. 11. CTZ14 South Zone.

Note that the "WWR $=0$ to 0.60 " label shows how the primary energy use or peak demand is plotted as a function of window-to-wall area ratio (WWR) with WWR $=0$ on the left and WWR $=0.60$ on the right side of the double-headed arrow and WWR $=0.15,0.30$, and 0.45 as points on each line. Data for all window types (dpclear, bronze, etc.) are plotted as a function of WWR. All cases are plotted for each window type.

\section{Tables 11-42:}

Four conditions:

- Title 24-2005 or ASHRAE 90.1-1999 as base case (Tables 11-18)

- Best commercially-available window (type F) (Tables 19-26)

- Best commercially-available window (type F) with attached shading (Tables 27-34)

- Best commercially-available window (type F) with horizon (urban) obstructions (Tables 35-42)

And for each condition, data are given in the following order:

- Primary Annual Energy Use Savings (kBtu/ft ${ }^{2}$-floor-yr), WWR $=0.30$

- Percentage Primary Annual Energy Use Savings (\%), WWR=0.30

- Primary Annual Energy Use Savings ( $\mathrm{kBtu} / \mathrm{ft}^{2}$-floor-yr), $\mathrm{WWR}=0.60$

- Percentage Primary Annual Energy Use Savings (\%), WWR=0.60

- Peak Demand Savings $\left(\mathrm{W} / \mathrm{ft}^{2}\right), \mathrm{WWR}=0.30$

- Percentage Peak Demand Savings (\%), WWR $=0.30$

- Peak Demand Savings ( $\left./ \mathrm{W} / \mathrm{ft}^{2}\right), \mathrm{WWR}=0.60$

- Percentage Peak Demand Savings (\%), WWR $=0.60$

where,

- $\mathrm{B}=$ base case, $\mathrm{E}=$ electrochromic window case

- $\mathrm{N}=$ No, $\mathrm{Y}=$ Yes

- Daylight? = does this case have daylighting controls?

- Shade? = does this case have an hourly-deployed interior shade?

- Climate =1-16 are California climate zones CTZ1-16

- Data are given for perimeter zones oriented due north, east, south, and west. 

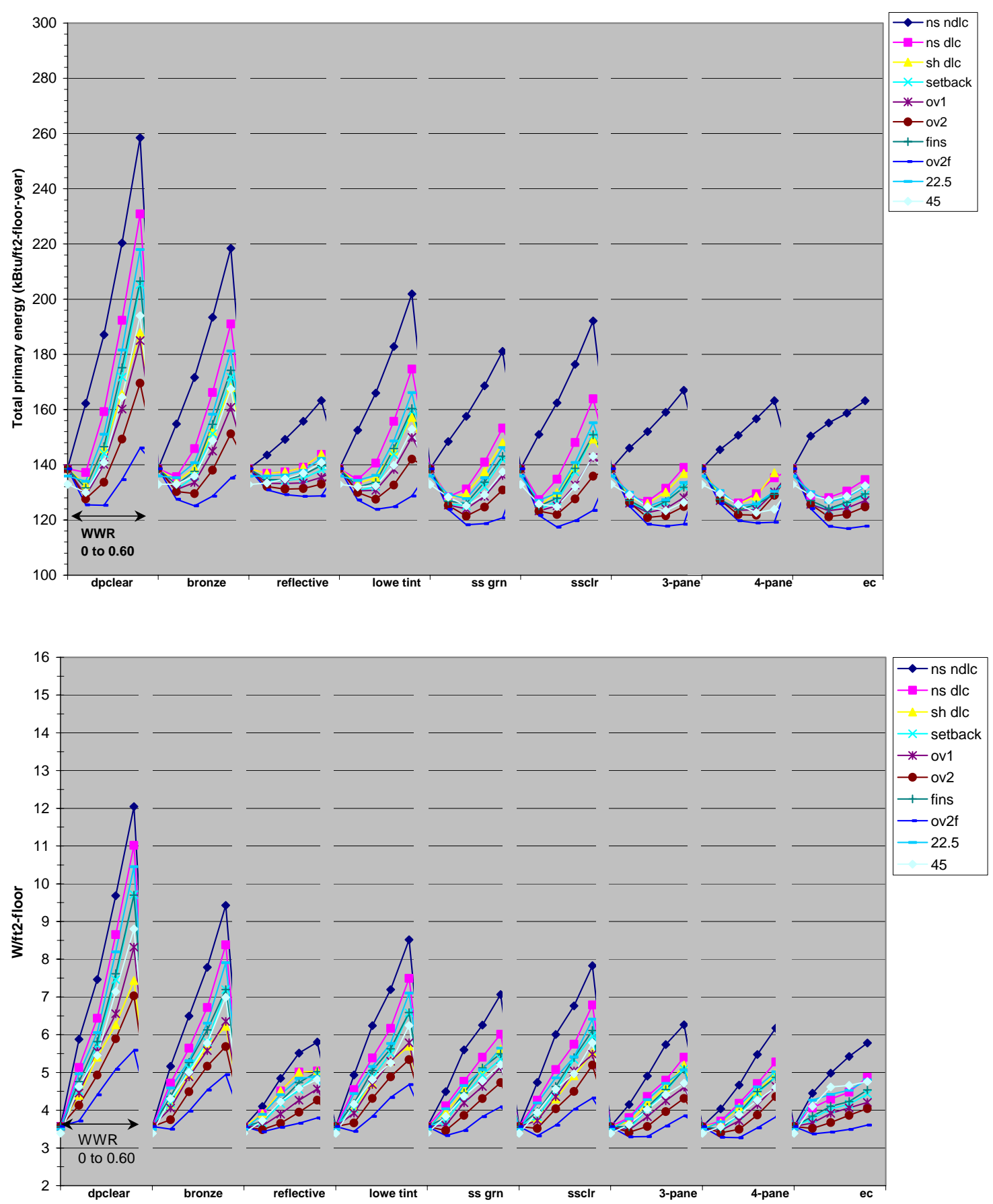

Fig. 6. Houston South Zone. Annual primary energy use (top, 3:1 fuel ratio) in the perimeter zone of a three-storey commercial office building prototype $\left(\mathrm{kBtu} / \mathrm{ft}^{2}\right.$-year) and peak demand (bottom, $\left.\mathrm{W} / \mathrm{ft}^{2}\right)$. Cases: $\mathrm{ns}=$ no interior shades; sh=interior shades; ndlc=no daylighting controls; dlc=daylighting controls; all the remaining cases have no interior shades with daylighting controls: setback $=1 \mathrm{ft}$, ov1=overhang case $A$, ov2=overhang case $\mathrm{B}$, ov $2 \mathrm{f}=$ overhang case $\mathrm{B}$ with fins, $22.5=$ =xterior obstructions with profile angle $22.5^{\circ}$, $45=$ exterior obstructions with profile angle $45^{\circ}$. 

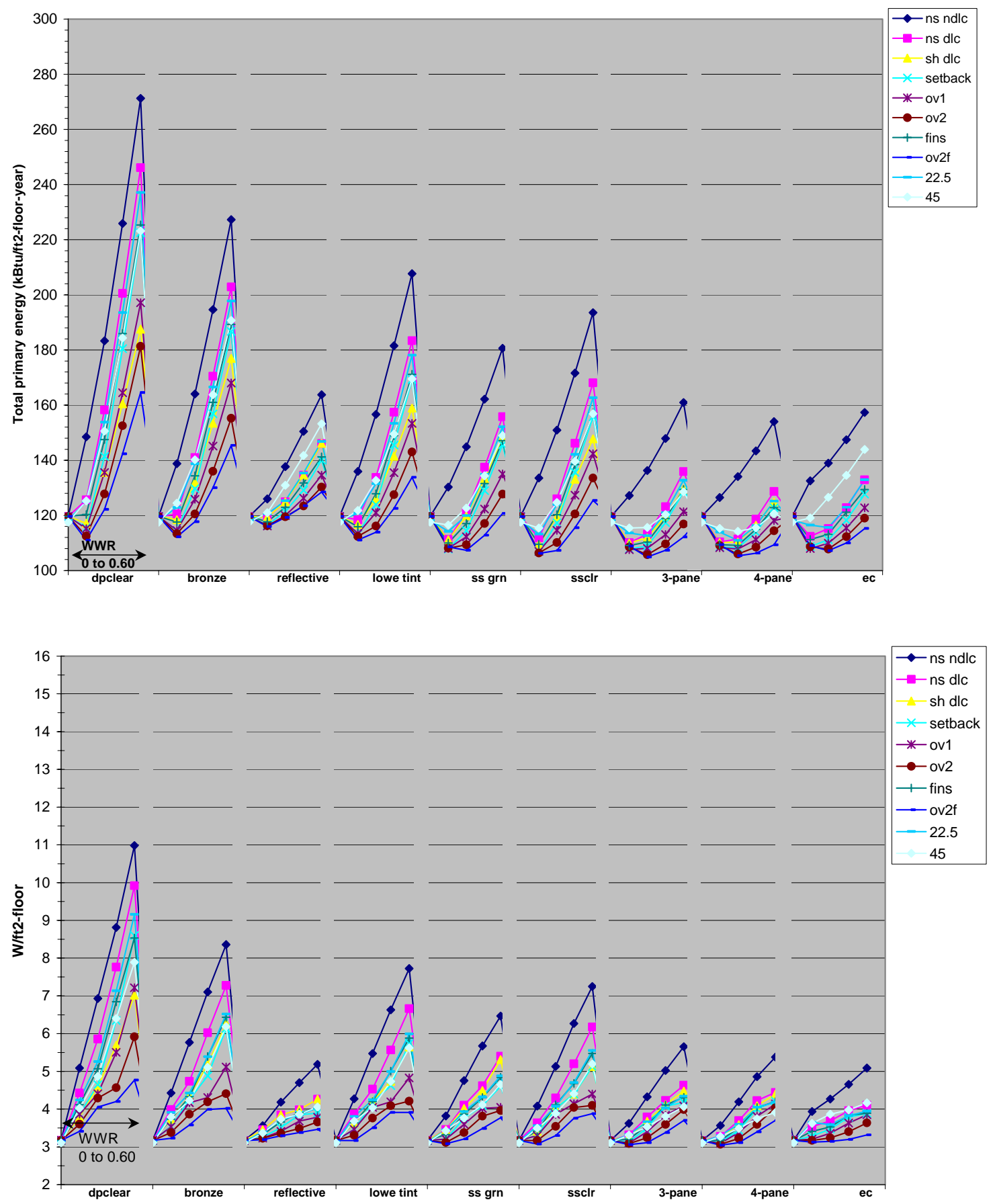

Fig. 7. Chicago South Zone. Annual primary energy use (top, 3:1 fuel ratio) in the perimeter zone of a three-storey commercial office building prototype (kBtu/ft${ }^{2}$-year) and peak demand (bottom, $\mathrm{W} / \mathrm{ft}^{2}$ ). Cases: ns=no interior shades; sh=interior shades; ndlc=no daylighting controls; dlc=daylighting controls; all the remaining cases have no interior shades with daylighting controls: setback $=1 \mathrm{ft}$, ov1=overhang case $A$, ov2=overhang case $\mathrm{B}$, ov2f=overhang case $\mathrm{B}$ with fins, $22.5=$ =xterior obstructions with profile angle $22.5^{\circ}$, $45=$ exterior obstructions with profile angle $45^{\circ}$. 

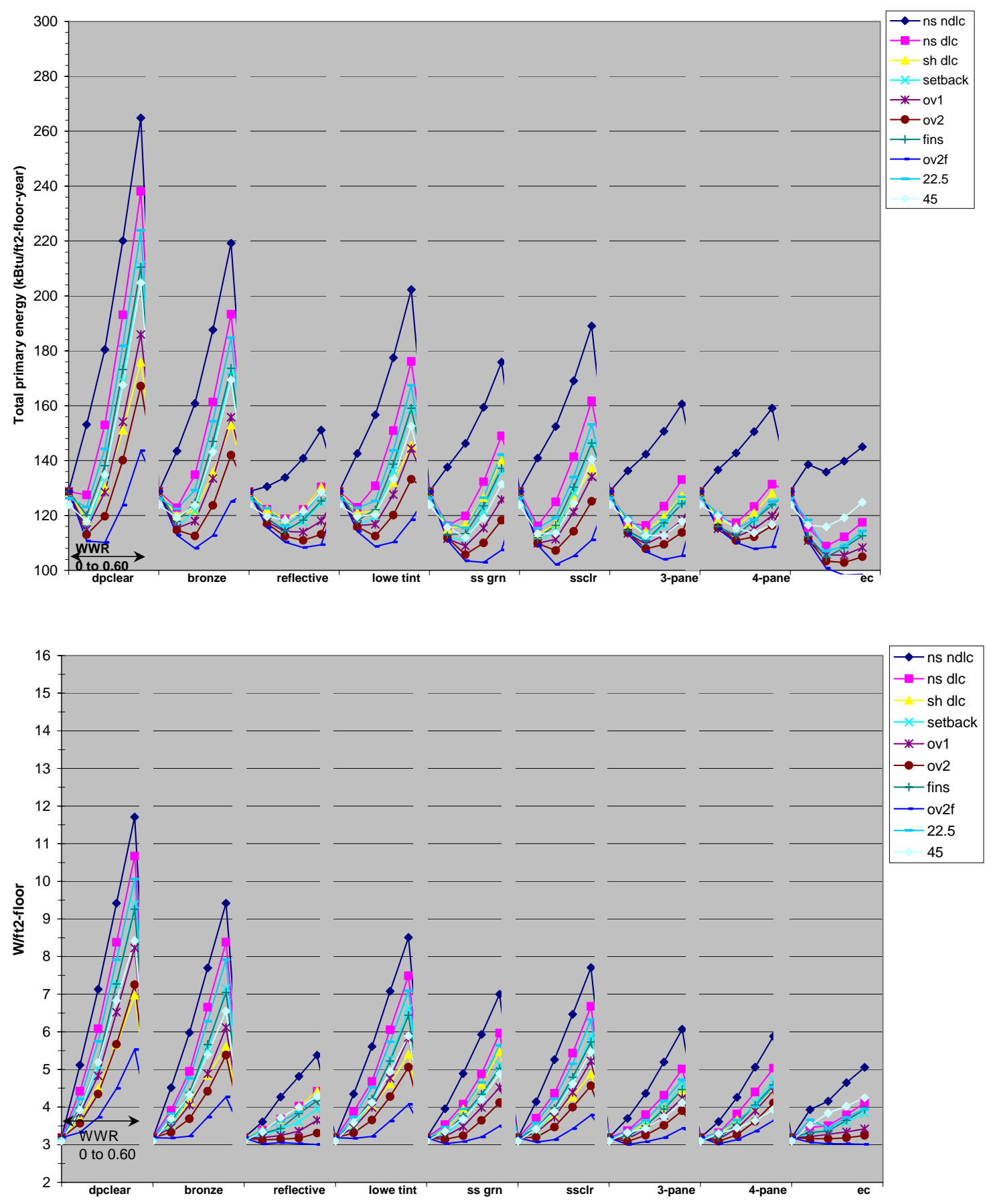

Fig. 8. California climate zone 3, South Zone. Annual primary energy use (top, 3:1 fuel ratio) in the perimeter zone of a three-storey commercial office building prototype ( $\mathrm{kBtu} / \mathrm{ft}^{2}$-year) and peak demand (bottom, W/ft ${ }^{2}$ ). Cases: ns=no interior shades; sh=interior shades; ndlc=no daylighting controls; dlc=daylighting controls; all the remaining cases have no interior shades with daylighting controls: setback $=1 \mathrm{ft}$, ov1=overhang case $A$, ov2=overhang case $B$, ov2 $\mathrm{f}=$ overhang case $\mathrm{B}$ with fins, $22.5=$ exterior obstructions with profile angle $22.5^{\circ}, 45=$ exterior obstructions with profile angle $45^{\circ}$. 

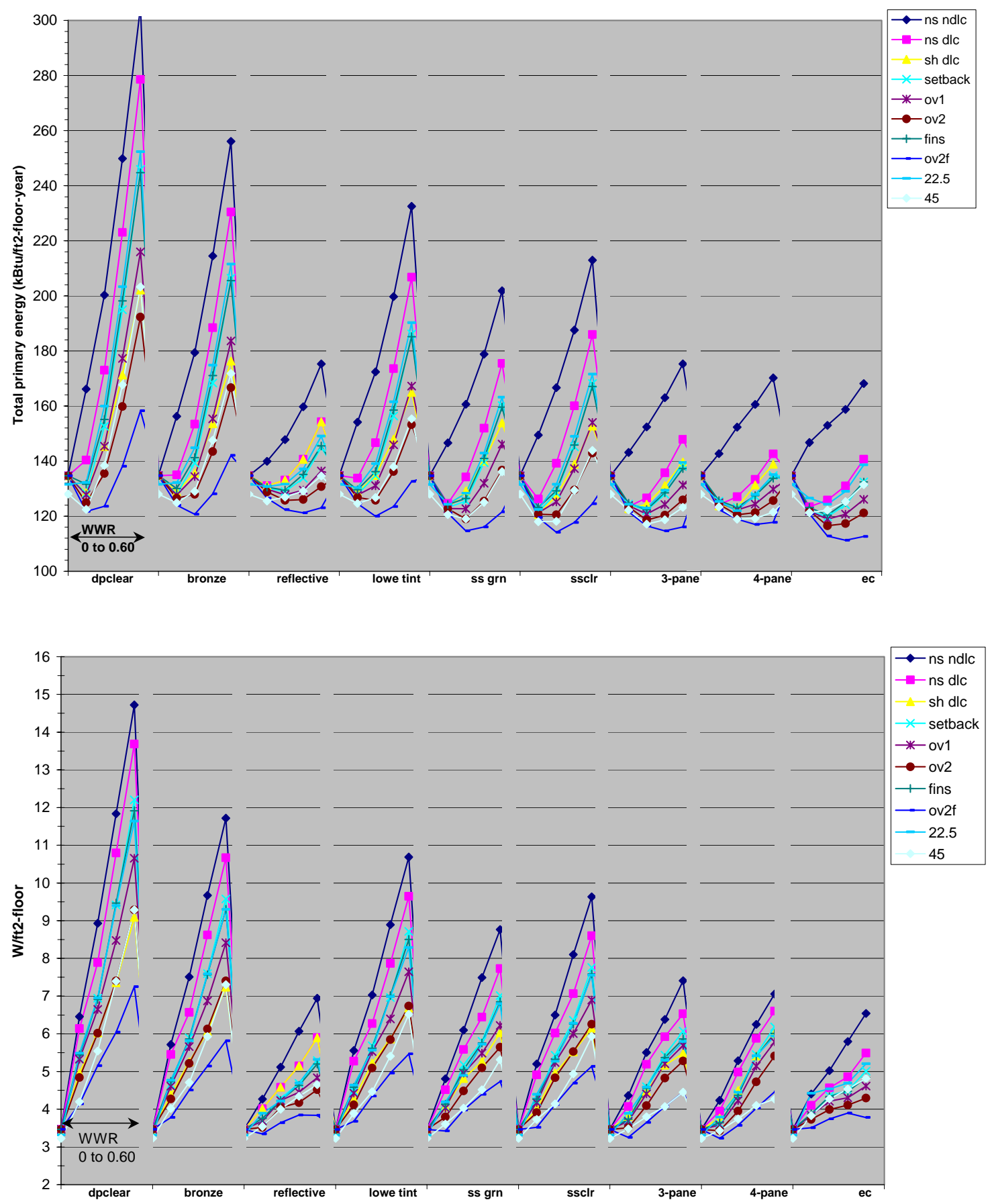

Fig. 9. California climate zone 9, South Zone. Annual primary energy use (top, 3:1 fuel ratio) in the perimeter zone of a three-storey commercial office building prototype ( $\mathrm{kBtu} / \mathrm{ft}^{2}$-year) and peak demand (bottom, $\mathrm{W} / \mathrm{ft}^{2}$ ). Cases: ns=no interior shades; sh=interior shades; ndlc=no daylighting controls; dlc=daylighting controls; all the remaining cases have no interior shades with daylighting controls: setback $=1 \mathrm{ft}$, ov1=overhang case $A$, ov2=overhang case $B$, ov2f=overhang case $B$ with fins, $22.5=$ exterior obstructions with profile angle $22.5^{\circ}, 45=$ exterior obstructions with profile angle $45^{\circ}$. 

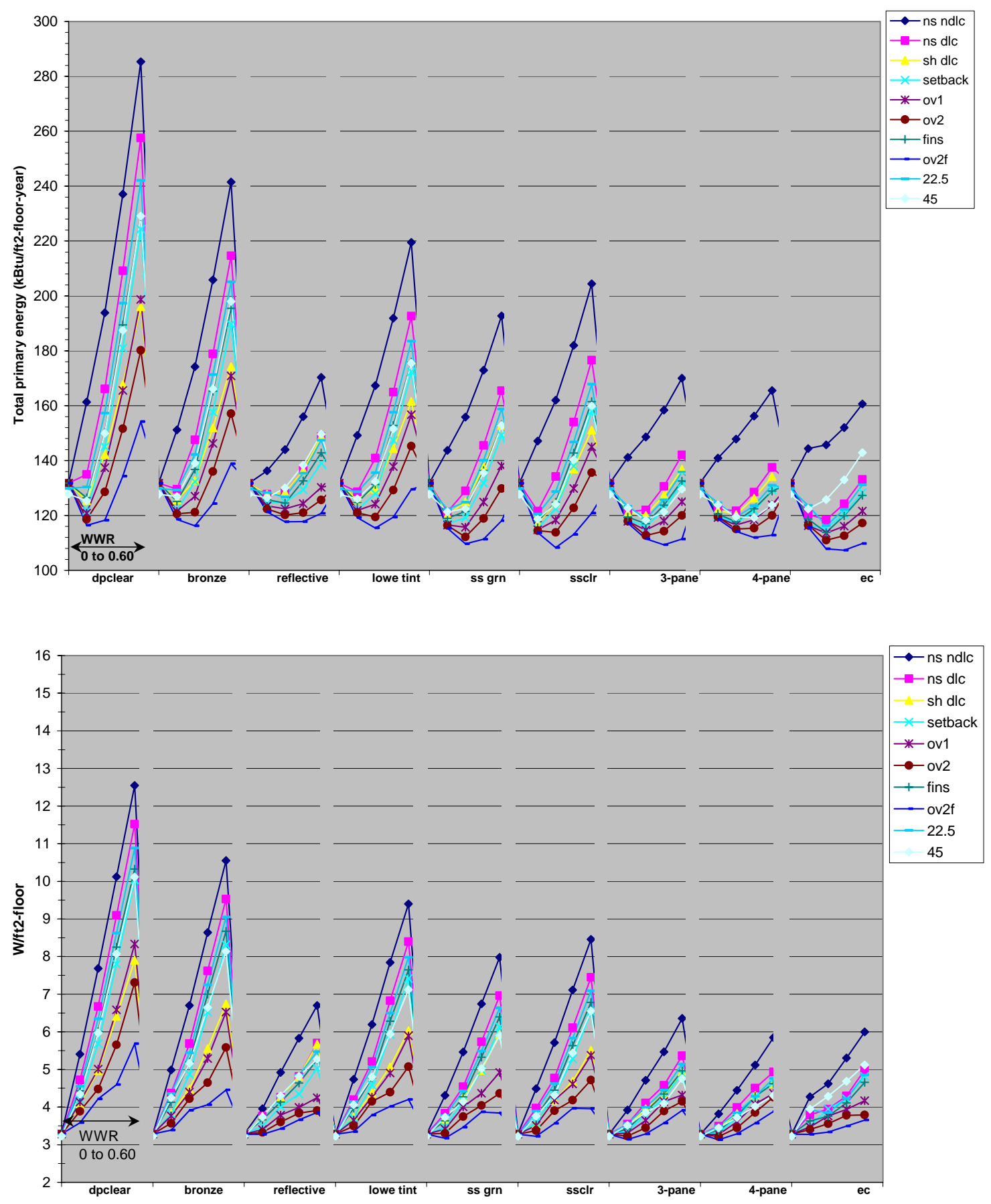

Fig. 10. California climate zone 12, South Zone. Annual primary energy use (top, 3:1 fuel ratio) in the perimeter zone of a three-storey commercial office building prototype ( $\mathrm{kBtu} / \mathrm{ft}^{2}$-year) and peak demand (bottom, W/ft ${ }^{2}$ ). Cases: ns=no interior shades; sh=interior shades; ndlc=no daylighting controls; dlc=daylighting controls; all the remaining cases have no interior shades with daylighting controls: setback=1 ft, ov1=overhang case A, ov2=overhang case B, ov2f=overhang case B with fins, $22.5=$ exterior obstructions with profile angle $22.5^{\circ}, 45=$ exterior obstructions with profile angle $45^{\circ}$. 

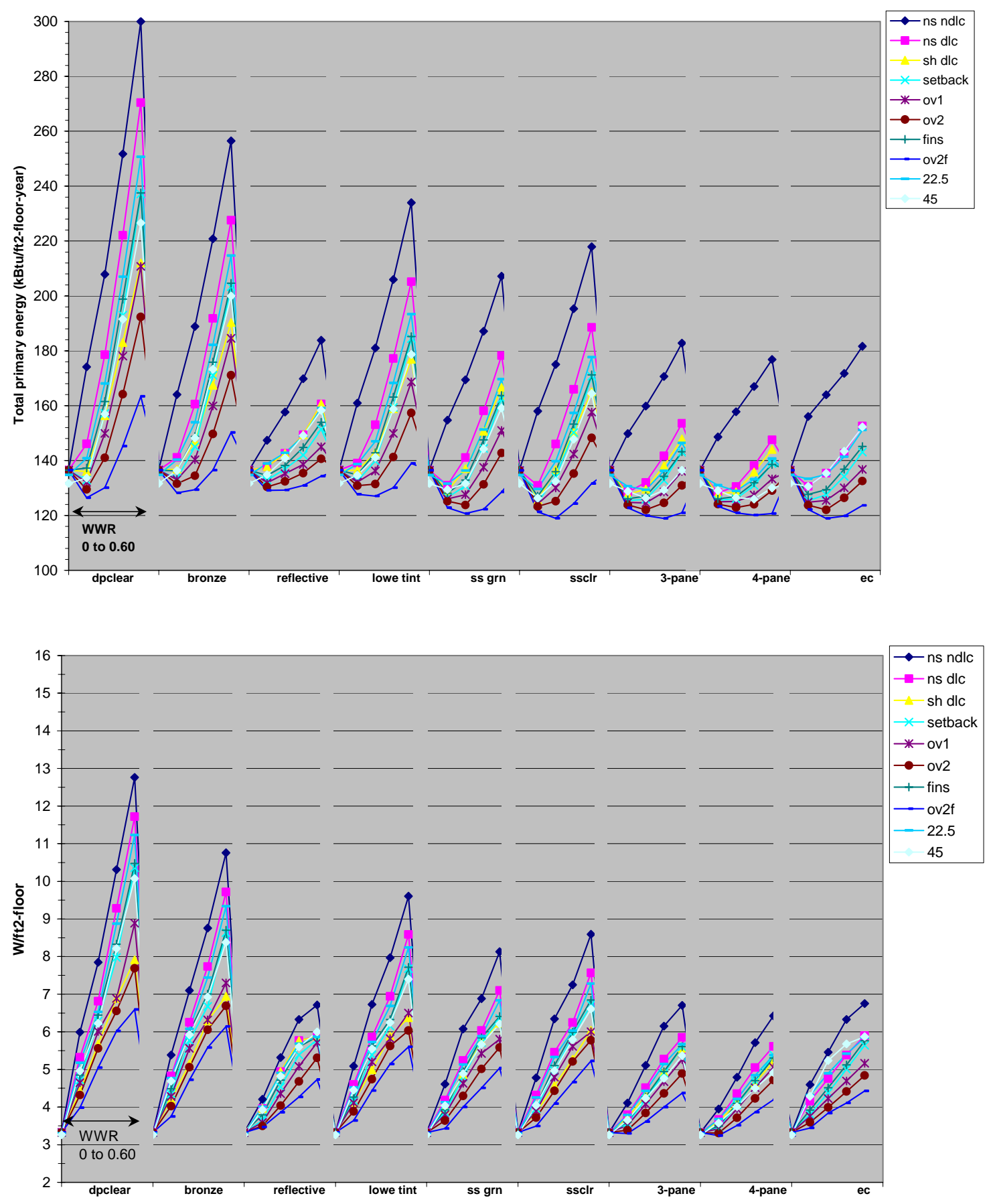

Fig. 11. California climate zone 14, South Zone. Annual primary energy use (top, 3:1 fuel ratio) in the perimeter zone of a three-storey commercial office building prototype ( $\mathrm{kBtu} / \mathrm{ft}^{2}$-year) and peak demand (bottom, W/ft ${ }^{2}$ ). Cases: ns=no interior shades; sh=interior shades; ndlc=no daylighting controls; dlc=daylighting controls; all the remaining cases have no interior shades with daylighting controls: setback=1 ft, ov1=overhang case A, ov2=overhang case B, ov2f=overhang case B with fins, $22.5=$ exterior obstructions with profile angle $22.5^{\circ}, 45=$ exterior obstructions with profile angle $45^{\circ}$. 
Table 11.

Primary Annual Energy Use Savings ( $\mathrm{kBtu} / \mathrm{ft}^{2}$-floor-yr)

Comparison to California Title-24-2005 Standard or ASHRAE 90.1-1999

EC with and without daylighting. Standard with no shade and no daylighting.

Window-to-wall ratio $=0.3$

\begin{tabular}{|c|c|c|c|c|c|c|c|c|c|c|c|c|c|c|c|c|}
\hline \multirow{2}{*}{\begin{tabular}{|c|} 
Zone \\
B Daylight? \\
\end{tabular}} & \multicolumn{4}{|l|}{ North } & \multicolumn{4}{|l|}{ East } & \multicolumn{4}{|l|}{ South } & \multicolumn{4}{|l|}{ West } \\
\hline & $\mathrm{N}$ & $\mathrm{N}$ & $\mathrm{N}$ & $\mathrm{N}$ & $\mathrm{N}$ & $\mathrm{N}$ & $\mathrm{N}$ & $\mathrm{N}$ & $\mathrm{N}$ & $\mathrm{N}$ & $\mathrm{N}$ & $\mathrm{N}$ & $\mathrm{N}$ & $\mathrm{N}$ & $\mathrm{N}$ & $\mathrm{N}$ \\
\hline B Shade? & $\mathrm{N}$ & $\mathrm{N}$ & $\mathrm{N}$ & $\mathrm{N}$ & $\mathrm{N}$ & $\mathrm{N}$ & $\mathrm{N}$ & $\mathrm{N}$ & $\mathrm{N}$ & $\mathrm{N}$ & $\mathrm{N}$ & $\mathrm{N}$ & $\mathrm{N}$ & $\mathrm{N}$ & $\mathrm{N}$ & $\mathrm{N}$ \\
\hline E Daylight? & $\mathrm{N}$ & $\mathrm{N}$ & $\mathrm{Y}$ & $\mathrm{Y}$ & $\mathrm{N}$ & $\mathrm{N}$ & $\mathrm{Y}$ & $\mathrm{Y}$ & $\mathrm{N}$ & $\mathrm{N}$ & $\mathrm{Y}$ & $\mathrm{Y}$ & $\mathrm{N}$ & $\mathrm{N}$ & $\mathrm{Y}$ & $\mathrm{Y}$ \\
\hline E Shade? & $\mathrm{N}$ & $\mathrm{N}$ & $\mathrm{N}$ & $\mathrm{N}$ & $\mathrm{N}$ & $\mathrm{N}$ & $\mathrm{N}$ & $\mathrm{N}$ & $\mathrm{N}$ & $\mathrm{N}$ & $\mathrm{N}$ & $\mathrm{N}$ & $\mathrm{N}$ & $\mathrm{N}$ & $\mathrm{N}$ & $\mathrm{N}$ \\
\hline \multicolumn{17}{|l|}{ Climate } \\
\hline 1 & 1.9 & 1.9 & 25.0 & 25.0 & 6.4 & 6.4 & 30.4 & 30.4 & 15.2 & 15.2 & 40.6 & 40.6 & 8.3 & 8.3 & 32.0 & 32.0 \\
\hline 2 & 1.6 & 1.6 & 26.1 & 26.1 & 2.6 & 2.6 & 27.9 & 27.9 & 8.7 & 8.7 & 35.3 & 35.3 & 4.2 & 4.2 & 29.3 & 29.3 \\
\hline 3 & 2.2 & 2.2 & 26.3 & 26.3 & 5.1 & 5.1 & 30.4 & 30.4 & 13.8 & 13.8 & 40.7 & 40.7 & 8.2 & 8.2 & 33.7 & 33.7 \\
\hline 4 & 2.5 & 2.5 & 26.8 & 26.8 & 4.8 & 4.8 & 30.2 & 30.2 & 7.9 & 7.9 & 35.0 & 35.0 & 7.7 & 7.7 & 33.4 & 33.4 \\
\hline 5 & 2.4 & 2.4 & 25.9 & 25.9 & 4.5 & 4.5 & 29.1 & 29.1 & 10.5 & 10.5 & 37.3 & 37.3 & 8.6 & 8.6 & 34.0 & 34.0 \\
\hline 6 & 4.6 & 4.6 & 28.0 & 28.0 & 3.6 & 3.6 & 27.4 & 27.4 & 9.1 & 9.1 & 34.8 & 34.8 & 7.9 & 7.9 & 32.3 & 32.3 \\
\hline 7 & 2.8 & 2.8 & 27.7 & 27.7 & 1.4 & 1.4 & 27.5 & 27.5 & 6.9 & 6.9 & 34.7 & 34.7 & 5.2 & 5.2 & 31.9 & 31.9 \\
\hline 8 & 3.1 & 3.1 & 27.8 & 27.8 & 1.4 & 1.4 & 27.8 & 27.8 & 6.8 & 6.8 & 34.9 & 34.9 & 4.7 & 4.7 & 31.5 & 31.5 \\
\hline 9 & 3.6 & 3.6 & 29.0 & 29.0 & $\begin{array}{ll}1.7 \\
\end{array}$ & 1.7 & 27.4 & 27.4 & 8.0 & 8.0 & 35.1 & 35.1 & 4.0 & 4.0 & 30.6 & 30.6 \\
\hline 10 & 2.6 & 2.6 & 28.5 & 28.5 & 1.6 & 1.6 & 27.9 & 27.9 & 7.0 & 7.0 & 34.6 & 34.6 & 4.4 & 4.4 & $\begin{array}{l}31.4 \\
\end{array}$ & 31.4 \\
\hline 11 & 1.0 & 1.0 & 24.7 & 24.7 & 7.0 & 7.0 & 31.7 & 31.7 & 11.8 & 11.8 & 38.4 & 38.4 & 5.4 & 5.4 & 30.1 & 30.1 \\
\hline 12 & 2.0 & 2.0 & 26.3 & 26.3 & 6.2 & 6.2 & 31.6 & 31.6 & 11.9 & 11.9 & 39.2 & 39.2 & 7.0 & 7.0 & 32.5 & 32.5 \\
\hline 13 & 2.9 & 2.9 & 27.6 & 27.6 & 6.4 & 6.4 & 31.7 & 31.7 & 7.4 & 7.4 & 34.8 & 34.8 & 6.8 & 6.8 & 32.4 & 32.4 \\
\hline 14 & 1.2 & 1.2 & 26.0 & 26.0 & 3.7 & 3.7 & 29.5 & 29.5 & 5.8 & 5.8 & 34.4 & 34.4 & 4.5 & 4.5 & 30.6 & 30.6 \\
\hline 15 & 1.5 & 1.5 & 28.3 & 28.3 & 5.6 & 5.6 & 32.3 & 32.3 & 7.7 & 7.7 & 36.0 & 36.0 & 4.7 & 4.7 & 32.6 & 32.6 \\
\hline 16 & 0.9 & 0.9 & 23.5 & 23.5 & 11.9 & 11.9 & 35.7 & 35.7 & 18.1 & 18.1 & 44.3 & 44.3 & 10.4 & 10.4 & 34.1 & 34.1 \\
\hline Houston & 9.0 & 9.0 & 34.3 & 34.3 & (2.8) & (2.8) & 23.1 & 23.1 & (2.6) & (2.6) & 24.4 & 24.4 & (2.2) & $(2.2)$ & 23.8 & 23.8 \\
\hline Phoenix & 11.5 & 11.5 & 36.9 & 36.9 & 1.1 & 1.1 & 28.0 & 28.0 & $(0.8)$ & (0.8) & 27.9 & 27.9 & 2.9 & 2.9 & 29.2 & 29.2 \\
\hline Atlanta & 1.2 & 1.2 & 25.3 & 25.3 & 8.0 & 8.0 & 33.2 & 33.2 & 9.0 & 9.0 & 35.5 & 35.5 & 7.8 & 7.8 & 32.6 & 32.6 \\
\hline Minneap & 5.0 & 5.0 & 26.2 & 26.2 & 8.8 & 8.8 & 30.8 & 30.8 & 13.6 & 13.6 & 37.5 & 37.5 & 10.6 & 10.6 & 32.8 & 32.8 \\
\hline Chicago & 4.8 & 4.8 & 26.6 & 26.6 & 10.1 & 10.1 & 32.4 & 32.4 & 12.3 & 12.3 & 36.1 & 36.1 & 6.3 & 6.3 & 28.7 & 28.7 \\
\hline Wash DC & 3.9 & 3.9 & 26.4 & 26.4 & 7.5 & 7.5 & 30.7 & 30.7 & 12.6 & 12.6 & 37.5 & 37.5 & 7.7 & 7.7 & 31.0 & 31.0 \\
\hline
\end{tabular}

Table 12.

Percentage Primary Annual Energy Use Savings

Comparison to California Title-24-2005 Standard or ASHRAE 90.1-1999

EC with and without daylighting. Standard with no shade and no daylighting.

Window-to-wall ratio $=0.3$

\begin{tabular}{|c|c|c|c|c|c|c|c|c|c|c|c|c|c|c|c|c|}
\hline \multirow{2}{*}{\begin{tabular}{c|} 
Zone \\
B Daylight?
\end{tabular}} & \multicolumn{4}{|l|}{ North } & \multicolumn{4}{|l|}{ East } & \multicolumn{4}{|l|}{ South } & \multicolumn{4}{|l|}{ West } \\
\hline & $\mathrm{N}$ & $\mathrm{N}$ & $\mathrm{N}$ & $\mathrm{N}$ & $\mathrm{N}$ & $\mathrm{N}$ & $\mathrm{N}$ & $\mathrm{N}$ & $\mathrm{N}$ & $\mathrm{N}$ & $\mathrm{N}$ & $\mathrm{N}$ & $\mathrm{N}$ & $\mathrm{N}$ & $\mathrm{N}$ & $\mathrm{N}$ \\
\hline B Shade? & $\mathrm{N}$ & $\mathrm{N}$ & $\mathrm{N}$ & $\mathrm{N}$ & $\mathrm{N}$ & $\mathrm{N}$ & $\mathrm{N}$ & $\mathrm{N}$ & $\mathrm{N}$ & $\mathrm{N}$ & $\mathrm{N}$ & $\mathrm{N}$ & $\mathrm{N}$ & $\mathrm{N}$ & $\mathrm{N}$ & $\mathrm{N}$ \\
\hline E Daylight? & $\mathrm{N}$ & $\mathrm{N}$ & $\mathrm{Y}$ & $\mathrm{Y}$ & $\mathrm{N}$ & $\mathrm{N}$ & $\mathrm{Y}$ & $\mathrm{Y}$ & $\mathrm{N}$ & $\mathrm{N}$ & $\mathrm{Y}$ & $\mathrm{Y}$ & $\mathrm{N}$ & $\mathrm{N}$ & $\mathrm{Y}$ & $\mathrm{Y}$ \\
\hline E Shade? & $\mathrm{N}$ & $\mathrm{N}$ & $\mathrm{N}$ & $\mathrm{N}$ & $\mathrm{N}$ & $\mathrm{N}$ & $\mathrm{N}$ & $\mathrm{N}$ & $\mathrm{N}$ & $\mathrm{N}$ & $\mathrm{N}$ & $\mathrm{N}$ & $\mathrm{N}$ & $\mathrm{N}$ & $\mathrm{N}$ & $\mathrm{N}$ \\
\hline \multicolumn{17}{|l|}{ Climate } \\
\hline 1 & 1.6 & 1.6 & 21.1 & 21.1 & 4.8 & 4.8 & 22.8 & 22.8 & 10.6 & 10.6 & 28.1 & 28.1 & 6.1 & 6.1 & 23.3 & 23.3 \\
\hline 2 & 1.2 & 1.2 & 19.8 & 19.8 & 1.7 & 1.7 & 18.7 & 18.7 & 5.6 & 5.6 & 22.6 & 22.6 & 2.8 & 2.8 & 19.7 & 19.7 \\
\hline 3 & 1.8 & 1.8 & 21.0 & 21.0 & 3.7 & 3.7 & 21.7 & 21.7 & 9.2 & 9.2 & 27.2 & 27.2 & 5.8 & 5.8 & 23.7 & 23.7 \\
\hline 4 & 1.9 & 1.9 & 20.7 & 20.7 & 3.3 & 3.3 & 20.8 & 20.8 & 5.2 & 5.2 & 22.9 & 22.9 & 5.3 & 5.3 & 22.9 & 22.9 \\
\hline 5 & 1.9 & 1.9 & 20.5 & 20.5 & 3.2 & 3.2 & 20.7 & 20.7 & 7.0 & 7.0 & 24.7 & 24.7 & 6.0 & 6.0 & 23.7 & 23.7 \\
\hline 6 & 3.4 & 3.4 & 20.5 & 20.5 & 2.4 & 2.4 & 18.5 & 18.5 & 5.8 & 5.8 & 22.0 & 22.0 & 5.2 & 5.2 & 21.1 & 21.1 \\
\hline 7 & 2.1 & 2.1 & 20.3 & 20.3 & 1.0 & 1.0 & 19.0 & 19.0 & 4.4 & 4.4 & 22.3 & 22.3 & 3.4 & 3.4 & 21.3 & 21.3 \\
\hline 8 & 2.2 & 2.2 & 20.5 & 20.5 & 1.0 & 1.0 & 18.8 & 18.8 & 4.3 & 4.3 & 21.9 & 21.9 & 3.1 & 3.1 & 20.7 & 20.7 \\
\hline 9 & 2.6 & 2.6 & 21.1 & 21.1 & 1.1 & 1.1 & 18.2 & 18.2 & 5.0 & 5.0 & 21.8 & 21.8 & 2.6 & 2.6 & 20.1 & 20.1 \\
\hline 10 & 1.9 & 1.9 & 20.6 & 20.6 & 1.1 & 1.1 & 18.3 & 18.3 & \begin{tabular}{l|}
4.3 \\
\end{tabular} & 4.3 & 21.3 & 21.3 & 2.9 & 2.9 & 20.4 & 20.4 \\
\hline 11 & 0.7 & 0.7 & 17.8 & 17.8 & 4.4 & 4.4 & 20.0 & 20.0 & 7.3 & 7.3 & 23.7 & 23.7 & 3.4 & 3.4 & 19.1 & 19.1 \\
\hline 12 & 1.5 & 1.5 & 19.6 & 19.6 & 4.0 & 4.0 & 20.6 & 20.6 & 7.5 & 7.5 & 24.9 & 24.9 & 4.6 & 4.6 & 21.3 & 21.3 \\
\hline 13 & 2.1 & 2.1 & 19.8 & 19.8 & 4.0 & 4.0 & 19.8 & 19.8 & 4.6 & 4.6 & 21.4 & 21.4 & 4.2 & 4.2 & 20.2 & 20.2 \\
\hline 14 & 0.9 & 0.9 & 18.1 & 18.1 & 2.2 & 2.2 & 17.8 & 17.8 & 3.4 & 3.4 & 20.2 & 20.2 & 2.7 & 2.7 & 18.7 & 18.7 \\
\hline 15 & 1.0 & 1.0 & 18.5 & 18.5 & 3.2 & 3.2 & 18.5 & 18.5 & 4.2 & 4.2 & 19.9 & 19.9 & 2.7 & 2.7 & 18.8 & 18.8 \\
\hline 16 & $\begin{array}{ll}0.7 \\
\end{array}$ & 0.7 & 18.4 & 18.4 & $\begin{array}{ll}7.7 \\
\end{array}$ & 7.7 & 23.1 & 23.1 & 11.4 & 11.4 & 28.0 & 28.0 & 6.8 & 6.8 & 22.2 & 22.2 \\
\hline Houston & 5.9 & 5.9 & 22.6 & 22.6 & (1.9) & (1.9) & 15.2 & 15.2 & (1.7) & (1.7) & 16.0 & 16.0 & (1.4) & (1.4) & 15.6 & 15.6 \\
\hline Phoenix & 7.1 & 7.1 & 22.8 & 22.8 & 0.7 & 0.7 & 16.4 & 16.4 & $(0.4)$ & $(0.4)$ & 16.3 & 16.3 & 1.7 & 1.7 & 17.1 & 17.1 \\
\hline Atlanta & 0.9 & 0.9 & 18.5 & 18.5 & 5.1 & 5.1 & 21.2 & 21.2 & 5.7 & 5.7 & 22.5 & 22.5 & 5.1 & 5.1 & 21.2 & 21.2 \\
\hline Minneap & 3.6 & 3.6 & 18.7 & 18.7 & 5.5 & 5.5 & 19.4 & 19.4 & 8.7 & 8.7 & 23.9 & 23.9 & 6.8 & 6.8 & 21.0 & 21.0 \\
\hline Chicago & 3.5 & 3.5 & 19.6 & 19.6 & 6.6 & 6.6 & 21.2 & 21.2 & 8.1 & 8.1 & 23.8 & 23.8 & 4.2 & 4.2 & 18.9 & 18.9 \\
\hline Wash DC & 2.9 & 2.9 & 19.2 & 19.2 & 4.9 & 4.9 & 20.1 & 20.1 & 8.2 & 8.2 & 24.3 & 24.3 & 5.0 & 5.0 & 20.3 & 20.3 \\
\hline
\end{tabular}


Table 13.

Primary Annual Energy Use Savings ( $\mathrm{kBtu} / \mathrm{ft}^{2}$-floor-yr)

Comparison to California Title-24-2005 Standard or ASHRAE 90.1-1999

EC with and without daylighting. Standard with no shade and no daylighting.

Window-to-wall ratio $=0.6$

\begin{tabular}{|c|c|c|c|c|c|c|c|c|c|c|c|c|c|c|c|c|}
\hline \multirow{2}{*}{$\begin{array}{c}\text { Zone } \\
\text { B Daylight? }\end{array}$} & \multicolumn{4}{|l|}{ North } & \multicolumn{4}{|l|}{ East } & \multicolumn{4}{|l|}{ South } & \multicolumn{4}{|l|}{ West } \\
\hline & $\mathrm{N}$ & $\mathrm{N}$ & $\mathrm{N}$ & $\mathrm{N}$ & $\mathrm{N}$ & $\mathrm{N}$ & $\mathrm{N}$ & $\mathrm{N}$ & $\mathrm{N}$ & $\mathrm{N}$ & $\mathrm{N}$ & $\mathrm{N}$ & $\mathrm{N}$ & $\mathrm{N}$ & $\mathrm{N}$ & $\mathrm{N}$ \\
\hline B Shade? & $\mathrm{N}$ & $\mathrm{N}$ & $\mathrm{N}$ & $\mathrm{N}$ & $\mathrm{N}$ & $\mathrm{N}$ & $\mathrm{N}$ & $\mathrm{N}$ & $\mathrm{N}$ & $\mathrm{N}$ & $\mathrm{N}$ & $\mathrm{N}$ & $\mathrm{N}$ & $\mathrm{N}$ & $\mathrm{N}$ & $\mathrm{N}$ \\
\hline E Daylight? & $\mathrm{N}$ & $\mathrm{N}$ & $\mathrm{Y}$ & $\mathrm{Y}$ & $\mathrm{N}$ & $\mathrm{N}$ & $\mathrm{Y}$ & $\mathrm{Y}$ & $\mathrm{N}$ & $\mathrm{N}$ & $\mathrm{Y}$ & $\mathrm{Y}$ & $\mathrm{N}$ & $\mathrm{N}$ & $\mathrm{Y}$ & $\mathrm{Y}$ \\
\hline E Shade? & $\mathrm{N}$ & $\mathrm{N}$ & $\mathrm{N}$ & $\mathrm{N}$ & $\mathrm{N}$ & $\mathrm{N}$ & $\mathrm{N}$ & $\mathrm{N}$ & $\mathrm{N}$ & $\mathrm{N}$ & $\mathrm{N}$ & $\mathrm{N}$ & $\mathrm{N}$ & $\mathrm{N}$ & $\mathrm{N}$ & $\mathrm{N}$ \\
\hline \multicolumn{17}{|l|}{ Climate } \\
\hline 1 & 2.2 & 2.2 & 28.0 & 28.0 & (2.6) & (2.6) & 22.5 & 22.5 & 4.1 & 4.1 & 29.3 & 29.3 & (4.5) & (4.5) & 19.8 & 19.8 \\
\hline 2 & (2.0) & (2.0) & 24.5 & 24.5 & (12.5) & (12.5) & 13.8 & 13.8 & (13.4) & (13.4) & 13.4 & 13.4 & (11.8) & (11.8) & 14.4 & 14.4 \\
\hline 3 & 3.1 & 3.1 & 30.3 & 30.3 & (1.6) & (1.6) & 25.3 & 25.3 & 4.5 & 4.5 & 32.0 & 32.0 & 2.8 & 2.8 & 29.9 & 29.9 \\
\hline 4 & 2.6 & 2.6 & 30.0 & 30.0 & (4.9) & (4.9) & 22.1 & 22.1 & (4.3) & (4.3) & 23.6 & 23.6 & 1.3 & 1.3 & 28.8 & 28.8 \\
\hline 5 & 2.6 & 2.6 & 29.3 & 29.3 & (7.3) & (7.3) & 18.5 & 18.5 & 0.3 & 0.3 & 27.4 & 27.4 & 3.6 & 3.6 & 30.7 & 30.7 \\
\hline 6 & 2.0 & 2.0 & 30.2 & 30.2 & (5.4) & $(5.4)$ & 22.4 & 22.4 & (2.3) & (2.3) & 25.8 & 25.8 & \begin{tabular}{l|l}
$(0.1)$ \\
\end{tabular} & $(0.1)$ & 28.2 & 28.2 \\
\hline 7 & 2.7 & 2.7 & 30.9 & 30.9 & (2.4) & $(2.4)$ & 25.9 & 25.9 & 0.8 & 0.8 & 29.5 & 29.5 & 1.3 & 1.3 & 29.8 & 29.8 \\
\hline 8 & 0.9 & 0.9 & 29.3 & 29.3 & (6.6) & (6.6) & 21.6 & 21.6 & (5.3) & (5.3) & 23.3 & 23.3 & (3.7) & (3.7) & 24.6 & 24.6 \\
\hline 9 & 2.7 & 2.7 & 30.5 & 30.5 & (8.0) & $(8.0)$ & 19.1 & 19.1 & $(7.2)$ & $(7.2)$ & 20.3 & 20.3 & (3.3) & (3.3) & 24.2 & 24.2 \\
\hline 10 & (1.0) & (1.0) & 26.9 & 26.9 & \begin{tabular}{|c|}
$(11.4)$ \\
\end{tabular} & (11.4) & 16.4 & 16.4 & (11.7) & \begin{tabular}{|l|}
$(11.7)$ \\
\end{tabular} & 16.4 & 16.4 & (8.2) & $(8.2)$ & 19.6 & 19.6 \\
\hline 11 & (6.1) & (6.1) & 20.2 & 20.2 & (7.8) & $(7.8)$ & 18.5 & 18.5 & (4.7) & (4.7) & 22.3 & 22.3 & (10.8) & $(10.8)$ & 15.2 & 15.2 \\
\hline 12 & (1.6) & (1.6) & 25.4 & 25.4 & (8.3) & (8.3) & 18.1 & 18.1 & (3.1) & (3.1) & 24.4 & 24.4 & (7.9) & (7.9) & 18.5 & 18.5 \\
\hline 13 & (2.6) & (2.6) & 24.7 & 24.7 & (8.5) & (8.5) & 18.2 & 18.2 & $(8.4)$ & $(8.4)$ & 19.3 & 19.3 & (10.1) & $(10.1)$ & 16.7 & 16.7 \\
\hline 14 & (6.4) & (6.4) & 21.5 & 21.5 & (14.1) & (14.1) & 13.6 & 13.6 & (11.9) & (11.9) & 17.2 & 17.2 & (12.8) & (12.8) & 14.9 & 14.9 \\
\hline 15 & (5.5) & (5.5) & 23.0 & 23.0 & (8.1) & (8.1) & 20.2 & 20.2 & (7.3) & (7.3) & 21.7 & 21.7 & (8.5) & (8.5) & 20.1 & 20.1 \\
\hline 16 & (7.0) & $(7.0)$ & 18.1 & 18.1 & (7.1) & (7.1) & 17.6 & 17.6 & 1.0 & 1.0 & 27.0 & 27.0 & $(10.0)$ & $(10.0)$ & 14.6 & 14.6 \\
\hline Houston & 6.9 & 6.9 & 35.0 & 35.0 & (9.1) & (9.1) & 18.7 & 18.7 & $(9.7)$ & (9.7) & 18.8 & 18.8 & (8.7) & $(8.7)$ & 19.1 & 19.1 \\
\hline Phoenix & 10.8 & 10.8 & 39.4 & 39.4 & (6.4) & (6.4) & 22.4 & 22.4 & (11.7) & $(11.7)$ & 17.8 & 17.8 & (4.0) & (4.0) & 24.3 & 24.3 \\
\hline Atlanta & (2.1) & (2.1) & 24.5 & 24.5 & (2.8) & (2.8) & 24.0 & 24.0 & (4.3) & (4.3) & 23.1 & 23.1 & (3.2) & (3.2) & 22.3 & 22.3 \\
\hline Minneap & 0.9 & 0.9 & 24.4 & 24.4 & (9.7) & (9.7) & 13.8 & 13.8 & (3.1) & (3.1) & 21.6 & 21.6 & $(4.2)$ & $(4.2)$ & 19.8 & 19.8 \\
\hline Chicago & (2.7) & (2.7) & 21.2 & 21.2 & (9.0) & $(9.0)$ & 14.6 & 14.6 & (5.2) & (5.2) & 19.3 & 19.3 & (13.6) & (13.6) & 10.1 & 10.1 \\
\hline Wash DC & (2.1) & $(2.1)$ & 22.6 & 22.6 & (11.1) & (11.1) & 13.4 & 13.4 & (6.3) & (6.3) & 19.4 & 19.4 & (8.1) & $(8.1)$ & 16.8 & 16.8 \\
\hline
\end{tabular}

Table 14.

Percentage Primary Annual Energy Use Savings

Comparison to California Title-24-2005 Standard or ASHRAE 90.1-1999

EC with and without daylighting. Standard with no shade and no daylighting.

Window-to-wall ratio $=0.6$

\begin{tabular}{|c|c|c|c|c|c|c|c|c|c|c|c|c|c|c|c|c|}
\hline \multirow{2}{*}{$\begin{array}{c}\text { Zone } \\
\text { B Daylight? }\end{array}$} & \multicolumn{4}{|l|}{ North } & \multicolumn{4}{|l|}{ East } & \multicolumn{4}{|l|}{ South } & \multicolumn{4}{|l|}{ West } \\
\hline & $\mathrm{N}$ & $\mathrm{N}$ & $\mathrm{N}$ & $\mathrm{N}$ & $\mathrm{N}$ & $\mathrm{N}$ & $\mathrm{N}$ & $\mathrm{N}$ & $\mathrm{N}$ & $\mathrm{N}$ & $\mathrm{N}$ & $\mathrm{N}$ & $\mathrm{N}$ & $\mathrm{N}$ & $\mathrm{N}$ & $\mathrm{N}$ \\
\hline B Shade? & $\mathrm{N}$ & $\mathrm{N}$ & $\mathrm{N}$ & $\mathrm{N}$ & $\mathrm{N}$ & $\mathrm{N}$ & $\mathrm{N}$ & $\mathrm{N}$ & $\mathrm{N}$ & $\mathrm{N}$ & $\mathrm{N}$ & $\mathrm{N}$ & $\mathrm{N}$ & $\mathrm{N}$ & $\mathrm{N}$ & $\mathrm{N}$ \\
\hline E Daylight? & $\mathrm{N}$ & $\mathrm{N}$ & $\mathrm{Y}$ & $\mathrm{Y}$ & $\mathrm{N}$ & $\mathrm{N}$ & $\mathrm{Y}$ & $\mathrm{Y}$ & $\mathrm{N}$ & $\mathrm{N}$ & $\mathrm{Y}$ & $\mathrm{Y}$ & $\mathrm{N}$ & $\mathrm{N}$ & $\mathrm{Y}$ & $\mathrm{Y}$ \\
\hline E Shade? & $\mathrm{N}$ & $\mathrm{N}$ & $\mathrm{N}$ & $\mathrm{N}$ & $\mathrm{N}$ & $\mathrm{N}$ & $\mathrm{N}$ & $\mathrm{N}$ & $\mathrm{N}$ & $\mathrm{N}$ & $\mathrm{N}$ & $\mathrm{N}$ & $\mathrm{N}$ & $\mathrm{N}$ & $\mathrm{N}$ & $\mathrm{N}$ \\
\hline \multicolumn{17}{|l|}{ Climate } \\
\hline 1 & 1.9 & 1.9 & 23.6 & 23.6 & (1.9) & (1.9) & 16.9 & 16.9 & 2.8 & 2.8 & 20.3 & 20.3 & (3.3) & (3.3) & 14.5 & 14.5 \\
\hline 2 & (1.5) & (1.5) & 18.6 & 18.6 & (8.4) & (8.4) & 9.3 & 9.3 & (8.6) & (8.6) & 8.6 & 8.6 & (7.9) & (7.9) & 9.7 & 9.7 \\
\hline 3 & 2.5 & 2.5 & 24.2 & 24.2 & $(1.2)$ & $(1.2)$ & 18.1 & 18.1 & 3.0 & 3.0 & 21.4 & 21.4 & 1.9 & 1.9 & 21.0 & 21.0 \\
\hline 4 & 2.0 & 2.0 & 23.2 & 23.2 & (3.4) & (3.4) & 15.2 & 15.2 & $(2.8)$ & (2.8) & 15.5 & 15.5 & 0.9 & 0.9 & 19.7 & 19.7 \\
\hline 5 & 2.1 & 2.1 & 23.1 & 23.1 & (5.2) & (5.2) & 13.1 & 13.1 & 0.2 & 0.2 & 18.2 & 18.2 & 2.5 & 2.5 & 21.3 & 21.3 \\
\hline 6 & 1.5 & 1.5 & 22.1 & 22.1 & (3.7) & (3.7) & 15.2 & 15.2 & (1.5) & (1.5) & 16.3 & 16.3 & $\begin{array}{l}(0.1) \\
\end{array}$ & $(0.1)$ & 18.5 & 18.5 \\
\hline 7 & 2.0 & 2.0 & 22.7 & 22.7 & (1.7) & (1.7) & 17.9 & 17.9 & 0.5 & 0.5 & 18.9 & 18.9 & 0.8 & 0.8 & 19.9 & 19.9 \\
\hline 8 & 0.7 & 0.7 & 21.5 & 21.5 & (4.5) & (4.5) & 14.6 & 14.6 & (3.3) & (3.3) & 14.6 & 14.6 & (2.4) & $(2.4)$ & 16.1 & 16.1 \\
\hline 9 & 2.0 & 2.0 & 22.2 & 22.2 & (5.3) & (5.3) & 12.7 & 12.7 & (4.4) & (4.4) & 12.6 & 12.6 & (2.2) & (2.2) & 15.9 & 15.9 \\
\hline 10 & (0.7) & (0.7) & 19.5 & 19.5 & (7.5) & (7.5) & 10.8 & 10.8 & $(7.2)$ & (7.2) & 10.1 & 10.1 & (5.4) & (5.4) & 12.7 & 12.7 \\
\hline 11 & (4.4) & (4.4) & 14.6 & 14.6 & (4.9) & (4.9) & 11.6 & 11.6 & (2.9) & (2.9) & 13.8 & 13.8 & (6.8) & (6.8) & 9.6 & 9.6 \\
\hline 12 & (1.2) & (1.2) & 19.0 & 19.0 & (5.4) & (5.4) & 11.8 & 11.8 & (1.9) & (1.9) & 15.5 & 15.5 & (5.2) & (5.2) & 12.1 & 12.1 \\
\hline 13 & (1.9) & (1.9) & 17.7 & 17.7 & (5.3) & (5.3) & 11.4 & 11.4 & $(5.2)$ & (5.2) & 11.9 & 11.9 & (6.3) & (6.3) & 10.4 & 10.4 \\
\hline 14 & (4.4) & (4.4) & 15.0 & 15.0 & (8.5) & (8.5) & 8.2 & 8.2 & $(7.0)$ & (7.0) & 10.1 & 10.1 & (7.8) & (7.8) & 9.1 & 9.1 \\
\hline 15 & (3.6) & (3.6) & 15.0 & 15.0 & (4.7) & (4.7) & 11.6 & 11.6 & (4.0) & $(4.0)$ & 12.0 & 12.0 & (4.9) & (4.9) & 11.6 & 11.6 \\
\hline 16 & (5.5) & (5.5) & 14.2 & 14.2 & (4.6) & (4.6) & 11.3 & 11.3 & 0.6 & 0.6 & 17.1 & 17.1 & (6.5) & (6.5) & 9.5 & 9.5 \\
\hline Houston & 4.5 & 4.5 & 22.6 & 22.6 & (5.9) & (5.9) & 12.1 & 12.1 & (6.3) & (6.3) & 12.3 & 12.3 & (5.6) & (5.6) & 12.3 & 12.3 \\
\hline Phoenix & \begin{tabular}{l|l}
6.4 \\
\end{tabular} & 6.4 & 23.4 & 23.4 & (3.7) & (3.7) & 12.9 & 12.9 & $(6.7)$ & (6.7) & 10.3 & 10.3 & (2.2) & $(2.2)$ & 13.8 & 13.8 \\
\hline Atlanta & (1.5) & (1.5) & 17.6 & 17.6 & (1.8) & (1.8) & 15.3 & 15.3 & $(2.7)$ & (2.7) & 14.6 & 14.6 & (2.1) & (2.1) & 14.4 & 14.4 \\
\hline Minneap & 0.6 & 0.6 & 16.3 & 16.3 & $(6.0)$ & (6.0) & 8.5 & 8.5 & $(2.0)$ & (2.0) & 13.6 & 13.6 & (2.6) & (2.6) & 12.5 & 12.5 \\
\hline Chicago & (1.9) & (1.9) & 15.2 & 15.2 & (5.8) & (5.8) & 9.4 & 9.4 & (3.4) & (3.4) & 12.7 & 12.7 & (8.8) & (8.8) & 6.5 & 6.5 \\
\hline Wash DC & (1.5) & (1.5) & 16.2 & 16.2 & (7.3) & (7.3) & 8.8 & 8.8 & (4.1) & (4.1) & 12.7 & 12.7 & (5.3) & (5.3) & 11.0 & 11.0 \\
\hline
\end{tabular}


Table 15.

Peak Demand Savings (W/ft2)

Comparison to California Title-24-2005 Standard or ASHRAE 90.1-1999

EC with and without daylighting. Standard with no shade and no daylighting.

Window-to-wall ratio $=0.3$

\begin{tabular}{|c|c|c|c|c|c|c|c|c|c|c|c|c|c|c|c|c|}
\hline Zone & North & & & & East & & & & South & & & & West & & & \\
\hline B Daylight? & $\mathrm{N}$ & $\mathrm{N}$ & $\mathrm{N}$ & $\mathrm{N}$ & $\mathrm{N}$ & $\mathrm{N}$ & $\mathrm{N}$ & $\mathrm{N}$ & $\mathrm{N}$ & $\mathrm{N}$ & $\mathrm{N}$ & $\mathrm{N}$ & $\mathrm{N}$ & $\mathrm{N}$ & $\mathrm{N}$ & $\mathrm{N}$ \\
\hline B Shade? & $\mathrm{N}$ & $\mathrm{N}$ & $\mathrm{N}$ & $\mathrm{N}$ & $\mathrm{N}$ & $\mathrm{N}$ & $\mathrm{N}$ & $\mathrm{N}$ & $\mathrm{N}$ & $\mathrm{N}$ & $\mathrm{N}$ & $\mathrm{N}$ & $\mathrm{N}$ & $\mathrm{N}$ & $\mathrm{N}$ & $\mathrm{N}$ \\
\hline E Daylight? & $\mathrm{N}$ & $\mathrm{N}$ & $\mathrm{Y}$ & $\mathrm{Y}$ & $\mathrm{N}$ & $\mathrm{N}$ & $\mathrm{Y}$ & $\mathrm{Y}$ & $\mathrm{N}$ & $\mathrm{N}$ & $\mathrm{Y}$ & $\mathrm{Y}$ & $\mathrm{N}$ & $\mathrm{N}$ & $\mathrm{Y}$ & $\mathrm{Y}$ \\
\hline E Shade? & $\mathrm{N}$ & $\mathrm{N}$ & $\mathrm{N}$ & $\mathrm{N}$ & $\mathrm{N}$ & $\mathrm{N}$ & $\mathrm{N}$ & $\mathrm{N}$ & $\mathrm{N}$ & $\mathrm{N}$ & $\mathrm{N}$ & $\mathrm{N}$ & $\mathrm{N}$ & $\mathrm{N}$ & $\mathrm{N}$ & $\mathrm{N}$ \\
\hline \multicolumn{17}{|l|}{ Climate } \\
\hline 1 & 0.1 & 0.1 & 0.5 & 0.5 & 0.6 & 0.6 & 1.3 & 1.3 & 0.8 & 0.8 & 1.5 & 1.5 & 0.5 & 0.5 & 1.3 & 1.3 \\
\hline 2 & 0.0 & 0.0 & 0.6 & 0.6 & 0.1 & 0.1 & 1.0 & 1.0 & 0.5 & 0.5 & 1.3 & 1.3 & 0.2 & 0.2 & 0.9 & 0.9 \\
\hline 3 & 0.1 & 0.1 & 0.6 & 0.6 & 0.6 & 0.6 & 1.3 & 1.3 & 1.1 & 1.1 & 1.7 & 1.7 & 0.8 & 8 & 1.5 & 1.5 \\
\hline 4 & 0.3 & 0.3 & 0.9 & 0.9 & 0.7 & 0.7 & 1.5 & 1.5 & 0.7 & 0.7 & 1.4 & 1.4 & 0.7 & 0.7 & 1.4 & 1.4 \\
\hline 5 & 0. & 0.3 & 0.8 & 0.8 & 0.6 & 0.6 & 1.3 & 1.3 & 1.0 & 1.0 & 1.7 & 1.7 & 0.9 & 0.9 & 1.5 & 1.5 \\
\hline 6 & 0. & 0.3 & 0.8 & 0.8 & 0.4 & 0.4 & 1.1 & 1.1 & 0.7 & 0.7 & 1.4 & 1.4 & 0.6 & 0.6 & 1.3 & 1.3 \\
\hline 7 & 0. & 0.4 & 0.8 & 0.8 & 0.7 & 0.7 & 1.3 & 1.3 & 0.9 & 0.9 & 1.4 & 1.4 & 0.9 & 0.9 & 1.5 & 1.5 \\
\hline 8 & 0.3 & 0.3 & 0.7 & 0.7 & 0.5 & 0.5 & 1.1 & 1.1 & 0.7 & 0.7 & 1.4 & 1.4 & 0.5 & 0.5 & 1.1 & 1.1 \\
\hline 9 & 0.4 & 0.4 & 0.7 & 0.7 & 0.6 & 0.6 & 1.0 & 1.0 & 1.1 & 1.1 & 1.6 & 1.6 & 0.6 & 0.6 & 1.1 & 1.1 \\
\hline 10 & 0.1 & 0.1 & 0.5 & 0.5 & 0.2 & 0.2 & 0.8 & 0.8 & 0.7 & 0.7 & 1.2 & 1.2 & 0.2 & 0.2 & 1.0 & 1.0 \\
\hline 1 & 0 & 0.1 & 0.6 & 0.6 & 0.6 & 0.6 & 1. & 1. & 0.9 & 0.9 & 1.4 & 1.4 & 0.4 & 0.4 & 1.1 & 1.1 \\
\hline 12 & 0.1 & 0.1 & 0.7 & 0.7 & 0.3 & 0.3 & 1.1 & 1.1 & 0.6 & 0.6 & 1.3 & 1.3 & 0.5 & 0.5 & 1.2 & 1.2 \\
\hline 13 & 0.2 & 0.2 & 0.7 & 0.7 & 0.4 & 0.4 & 1.1 & 1.1 & 0.3 & 0.3 & 1.1 & 1.1 & 0.4 & 0.4 & 1.1 & 1.1 \\
\hline 14 & 0.1 & 0.1 & 0.6 & 0.6 & 0.3 & 0.3 & 1.1 & 1.1 & 0.2 & 0.2 & 1.0 & 1.0 & 0.2 & 0.2 & 1.0 & 1.0 \\
\hline 15 & 0.1 & 0.1 & 0.6 & 0.6 & 0.5 & 0.5 & 1.1 & 1.1 & 0.6 & 0.6 & 1.2 & 1.2 & 0.5 & 0.5 & 1.1 & 1.1 \\
\hline 16 & 0.0 & 0.0 & 0.6 & 0.6 & 0.8 & 0.8 & 1.6 & 1.6 & 1.2 & 1.2 & 1.9 & 1.9 & 0.6 & 0.6 & 1.5 & 1.5 \\
\hline Houston & 0.6 & 0.6 & 1.2 & 1.2 & $(0.1)$ & $(0.1)$ & 0.5 & 0.5 & $(0.0)$ & $(0.0)$ & 0.7 & 0.7 & $(0.2)$ & $(0.2)$ & 0.5 & 0.5 \\
\hline Phoenix & 0.9 & 0.9 & 1.5 & 1.5 & 0.4 & 0.4 & 1.0 & 1.0 & 0.1 & 0.1 & 0.8 & 0.8 & 0.6 & 0.6 & 1.1 & 1.1 \\
\hline Atlanta & 0.2 & 0.2 & 0.6 & 0.6 & 0.6 & 0.6 & 1.2 & 1.2 & 0.4 & 0.4 & 1.1 & 1.1 & 0.7 & 0.7 & 1.4 & 1.4 \\
\hline Minneap & 0.2 & 0.2 & 0.6 & 0.6 & 0.5 & 0.5 & 1. & 1. & 0.9 & 0.9 & 1.6 & 1.6 & 0.5 & 0.5 & 1.1 & 1.1 \\
\hline Chicago & 0 & 0.2 & 0.7 & 0.7 & 0.6 & 0.6 & 1. & 1.3 & 0.8 & 0.8 & 1.3 & 1.3 & 0.3 & 0.3 & 1.0 & 1.0 \\
\hline Wash DC & 0.2 & 0.2 & 0.8 & 0.8 & 0.5 & 0.5 & 1.3 & 1.3 & 1.0 & 1.0 & 1.6 & 1.6 & 0.5 & 0.5 & 1.3 & 1.3 \\
\hline
\end{tabular}

Table 16.

Percentage Peak Demand Savings

Comparison to California Title-24-2005 Standard or ASHRAE 90.1-1999

EC with and without daylighting. Standard with no shade and no daylighting.

Window-to-wall ratio $=0.3$

\begin{tabular}{|c|c|c|c|c|c|c|c|c|c|c|c|c|c|c|c|c|}
\hline \multirow{2}{*}{\begin{tabular}{|c|} 
Zone \\
B Daylight? \\
\end{tabular}} & \multicolumn{4}{|l|}{ North } & \multicolumn{4}{|l|}{ East } & \multicolumn{4}{|l|}{ South } & \multicolumn{4}{|l|}{ West } \\
\hline & $\mathrm{N}$ & $\mathrm{N}$ & $\mathrm{N}$ & $\mathrm{N}$ & $\mathrm{N}$ & $\mathrm{N}$ & $\mathrm{N}$ & $\mathrm{N}$ & $\mathrm{N}$ & $\mathrm{N}$ & $\mathrm{N}$ & $\mathrm{Y}$ & $\mathrm{N}$ & $\mathrm{N}$ & $\mathrm{N}$ & $\mathrm{N}$ \\
\hline B Shade? & $\mathrm{N}$ & $\mathrm{N}$ & $\mathrm{N}$ & $\mathrm{N}$ & $\mathrm{N}$ & $\mathrm{N}$ & $\mathrm{N}$ & $\mathrm{N}$ & $\mathrm{N}$ & $\mathrm{N}$ & $\mathrm{N}$ & $\mathrm{N}$ & $\mathrm{N}$ & $\mathrm{N}$ & $\mathrm{N}$ & $\mathrm{N}$ \\
\hline E Daylight? & $\mathrm{N}$ & $\mathrm{N}$ & $\bar{Y}$ & $\bar{Y}$ & $\mathrm{~N}$ & $\mathrm{~N}$ & $\overline{Y Y}$ & $\bar{Y}$ & $\mathrm{~N}$ & $\mathrm{~N}$ & $\bar{Y}$ & $\bar{Y}$ & $\mathrm{~N}$ & $\mathrm{~N}$ & $\overline{\mathrm{Y}}$ & $\overline{\mathrm{Y}}$ \\
\hline E Shade? & $\mathrm{N}$ & $\mathrm{N}$ & $\mathrm{N}$ & $\mathrm{N}$ & $\mathrm{N}$ & $\mathrm{N}$ & $\mathrm{N}$ & $\mathrm{N}$ & $\mathrm{N}$ & $\mathrm{N}$ & $\mathrm{N}$ & $\mathrm{N}$ & $\mathrm{N}$ & $\mathrm{N}$ & $\mathrm{N}$ & $\mathrm{N}$ \\
\hline \multicolumn{17}{|l|}{ Climate } \\
\hline 1 & 2.6 & 2.6 & 16.0 & 16.0 & 13.1 & 13.1 & 27.4 & 27.4 & 16.4 & 16.4 & 30.4 & 30.4 & 10.7 & 10.7 & 26.9 & 26.9 \\
\hline 2 & 0.5 & 0.5 & 15.6 & 15.6 & 2.8 & 2.8 & 19.5 & 19.5 & 10.2 & 10.2 & 24.4 & 24.4 & 4.6 & 4.6 & 18.4 & 18.4 \\
\hline 3 & 4.1 & 4.1 & 18.0 & 18.0 & 13.0 & 13.0 & 27.5 & 27.5 & 20.7 & 20.7 & 33.1 & 33.1 & 15.4 & 15.4 & 29.7 & 29.7 \\
\hline 4 & 7.8 & 7.8 & 22.7 & 22.7 & 13.0 & 13.0 & 28.9 & 28.9 & 13.1 & 13.1 & 26.5 & 26.5 & 14.5 & 14.5 & 27.7 & 27.7 \\
\hline 5 & 8.4 & 8.4 & 20.3 & 20.3 & 11.2 & 11.2 & 25.7 & 25.7 & 18.7 & 18.7 & 31.2 & 31.2 & 17.0 & 17.0 & 29.9 & 29.9 \\
\hline 6 & 7.6 & 7.6 & 19.5 & 19.5 & 7.6 & 7.6 & 22.2 & 22.2 & 12.6 & 12.6 & 26.6 & 26.6 & 11.7 & 11.7 & 24.3 & 24.3 \\
\hline 7 & 8.8 & 8.8 & 20.3 & 20.3 & 13.3 & 13.3 & 26.6 & 26.6 & 16.4 & 16.4 & 26.7 & 26.7 & 16.6 & 16.6 & 29.1 & 29.1 \\
\hline 8 & 7.2 & 7.2 & 17.0 & 17.0 & 9.8 & 9.8 & 21.8 & 21.8 & 13.2 & 13.2 & 24.7 & 24.7 & 10.1 & 10.1 & 21.5 & 21.5 \\
\hline 9 & 9.2 & 9.2 & 16.5 & 16.5 & 10.5 & 10.5 & $\begin{array}{l}19.1 \\
\end{array}$ & 19.1 & 18.1 & 18.1 & 25.4 & 25.4 & 11.7 & 11.7 & 20.5 & 20.5 \\
\hline 10 & 2.3 & 2.3 & 13.5 & 13.5 & 3.7 & 3.7 & 16.9 & 16.9 & 11.8 & 11.8 & 22.0 & 22.0 & 4.7 & 4.7 & 18.2 & 18.2 \\
\hline 11 & 1.2 & 1.2 & 13.0 & 13.0 & 11.1 & 11.1 & 23.2 & 23.2 & 15.6 & 15.6 & 25.2 & 25.2 & 7.3 & 7.3 & 19.5 & 19.5 \\
\hline 12 & 2.0 & 2.0 & 17.6 & 17.6 & 6.2 & 6.2 & 22.1 & 22.1 & 12.3 & 12.3 & 25.1 & 25.1 & 8.5 & 8.5 & 23.4 & 23.4 \\
\hline 13 & 4.3 & 4.3 & 17.5 & 17.5 & 6.7 & 6.7 & 19.9 & 19.9 & 6.2 & 6.2 & 19.9 & 19.9 & 6.4 & 6.4 & 19.2 & 19.2 \\
\hline 14 & 1.3 & 1.3 & 14.3 & 14.3 & 5.3 & 5.3 & 19.3 & 19.3 & 4.4 & 4.4 & 16.7 & 16.7 & 3.7 & 3.7 & 17.4 & 17.4 \\
\hline 15 & 1.8 & 1.8 & 13.5 & 13.5 & 9.0 & 9.0 & 18.7 & 18.7 & 10.0 & 10.0 & 19.2 & 19.2 & 8.5 & 8.5 & 18.6 & 18.6 \\
\hline 16 & 0.5 & 0.5 & 14.8 & 14.8 & 13.2 & 13.2 & 27.0 & 27.0 & 19.5 & 19.5 & 31.7 & 31.7 & 10.7 & 10.7 & 24.6 & 24.6 \\
\hline Houston & 13.3 & 13.3 & 25.4 & 25.4 & (2.9) & (2.9) & 9.6 & 9.6 & $(0.3)$ & $(0.3)$ & 13.4 & 13.4 & (3.1) & (3.1) & 9.4 & 9.4 \\
\hline Phoenix & 16.9 & 16.9 & 26.9 & 26.9 & 6.4 & 6.4 & 17.2 & 17.2 & 1.2 & 1.2 & 13.7 & 13.7 & 8.9 & 8.9 & 17.2 & 17.2 \\
\hline Atlanta & 4.0 & 4.0 & 14.8 & 14.8 & 10.5 & 10.5 & 23.2 & 23.2 & 7.8 & 7.8 & 20.3 & 20.3 & 13.3 & 13.3 & 25.2 & 25.2 \\
\hline Minneap & 6.0 & 6.0 & 16.1 & 16.1 & 9.1 & 9.1 & 24.3 & 24.3 & 16.8 & 16.8 & 30.1 & 30.1 & 10.9 & 10.9 & 21.7 & 21.7 \\
\hline Chicago & 6.1 & 6.1 & 18.9 & 18.9 & 11.9 & 11.9 & 25.7 & 25.7 & 15.2 & 15.2 & 26.8 & 26.8 & 5.6 & 5.6 & 19.7 & 19.7 \\
\hline Wash DC & 5.8 & 5.8 & 20.6 & 20.6 & 9.8 & 9.8 & 24.1 & 24.1 & 17.5 & 17.5 & 29.3 & 29.3 & 10.2 & 10.2 & 23.9 & 23.9 \\
\hline
\end{tabular}


Table 17.

Peak Demand Savings (W/ft)

Comparison to California Title-24-2005 Standard or ASHRAE 90.1-1999

EC with and without daylighting. Standard with no shade and no daylighting.

Window-to-wall ratio $=0.6$

\begin{tabular}{|c|c|c|c|c|c|c|c|c|c|c|c|c|c|c|c|c|}
\hline Zone & North & & & & East & & & & South & & & & West & & & \\
\hline B Daylight? & $\mathrm{N}$ & $\mathrm{N}$ & $\mathrm{N}$ & $\mathrm{N}$ & $\mathrm{N}$ & $\mathrm{N}$ & $\mathrm{N}$ & $\mathrm{N}$ & $\mathrm{N}$ & $\mathrm{N}$ & $\mathrm{N}$ & $\mathrm{N}$ & $\mathrm{N}$ & $\mathrm{N}$ & $\mathrm{N}$ & $\mathrm{N}$ \\
\hline B Shade? & $\mathrm{N}$ & $\mathrm{N}$ & $\mathrm{N}$ & $\mathrm{N}$ & $\mathrm{N}$ & $\mathrm{N}$ & $\mathrm{N}$ & $\mathrm{N}$ & $\mathrm{N}$ & $\mathrm{N}$ & $\mathrm{N}$ & $\mathrm{N}$ & $\mathrm{N}$ & $\mathrm{N}$ & $\mathrm{N}$ & $\mathrm{N}$ \\
\hline E Daylight? & $\mathrm{N}$ & $\mathrm{N}$ & $\mathrm{Y}$ & $\mathrm{Y}$ & $\mathrm{N}$ & $\mathrm{N}$ & $\mathrm{Y}$ & $\mathrm{Y}$ & $\mathrm{N}$ & $\mathrm{N}$ & $\mathrm{Y}$ & $\mathrm{Y}$ & $\mathrm{N}$ & $\mathrm{N}$ & $\mathrm{Y}$ & $\mathrm{Y}$ \\
\hline E Shade? & $\mathrm{N}$ & $\mathrm{N}$ & $\mathrm{N}$ & $\mathrm{N}$ & $\mathrm{N}$ & $\mathrm{N}$ & $\mathrm{N}$ & $\mathrm{N}$ & $\mathrm{N}$ & $\mathrm{N}$ & $\mathrm{N}$ & $\mathrm{N}$ & $\mathrm{N}$ & $\mathrm{N}$ & $\mathrm{N}$ & $\mathrm{N}$ \\
\hline Climate & & & & & & & & & & & & & & & & \\
\hline 1 & 0.0 & 0.0 & 0.5 & 0.5 & 0.1 & 0.1 & 0.9 & 0.9 & $(0.1)$ & $(0.1)$ & 0.9 & 0.9 & $(0.4)$ & $(0.4)$ & 0.6 & 0.6 \\
\hline 2 & $(0.3)$ & $(0.3)$ & 0.4 & 0.4 & (1.1) & $(1.1)$ & $(0.1)$ & $(0.1)$ & $(0.8)$ & $(0.8)$ & 0.2 & 0.2 & $(0.8)$ & $(0.8)$ & 0.2 & 0.2 \\
\hline 3 & 0 & 0. & 0.6 & 0.6 & $(0.2)$ & $(0.2)$ & 0.8 & 0.8 & 0.2 & 0.2 & 1.1 & 1.1 & 0.1 & 0.1 & 1.0 & 1.0 \\
\hline 4 & 0.2 & 0.2 & 0.8 & 0.8 & $(0.3)$ & $(0$. & 0.6 & 0.6 & $(0.4)$ & $(0.4)$ & 0.6 & 0.6 & 0.0 & 0.0 & 1.0 & 1.0 \\
\hline 5 & 0. & 0.1 & 0.8 & 0.8 & $(0.4)$ & $(0.4)$ & 0.6 & 0.6 & 0.1 & 0.1 & 1.1 & 1.1 & 0.3 & .3 & 1.2 & 1.2 \\
\hline 6 & (0.1) & $\begin{array}{l}(0.1) \\
\end{array}$ & 0.6 & 0.6 & $(0.7)$ & $(0.7)$ & 0. & 0.3 & $(0.4)$ & $(0.4)$ & 0.7 & 0.7 & $(0.3)$ & $(0.3)$ & 0.7 & 0.7 \\
\hline 7 & 0.0 & 0.0 & 0.7 & 0.7 & $(0.1)$ & $(0.1)$ & 0.9 & 0.9 & 0.0 & 0.0 & 1.1 & 1.1 & 0.1 & 0.1 & 1.1 & 1.1 \\
\hline 8 & $(0.1)$ & $(0.1)$ & 0.5 & 0.5 & $(0.6)$ & $(0.6)$ & 0.4 & 0.4 & $(0.6)$ & $(0.6)$ & 0.4 & 0.4 & $(0.5)$ & $(0.5)$ & .5 & 0.5 \\
\hline 9 & 0.1 & 0.1 & 0.5 & 0.5 & $(0.7)$ & $(0.7)$ & 0.2 & 0.2 & $(0.4)$ & $(0.4)$ & 0.6 & 0.6 & $(0.3)$ & (0.3) & 0.7 & 0.7 \\
\hline 11 & (0.3) & $\begin{array}{l}(0.3) \\
\end{array}$ & 0.3 & 0.3 & (1.1) & (1.1) & $(0.0)$ & $(0.0)$ & (1.1) & (1.1) & $\begin{array}{l}(0.0) \\
\end{array}$ & $\begin{array}{l}(0.0) \\
\end{array}$ & $(0.8)$ & $\begin{array}{l}(0.8) \\
\end{array}$ & 0.2 & 0.2 \\
\hline 11 & $(0.5$ & $(0.5)$ & 0.3 & 0.3 & $(0.5)$ & $(0$. & 0.2 & 0.4 & $(0.3)$ & $(0.3)$ & 0.5 & 0.5 & $(0.5)$ & $(0.5)$ & 0.3 & 0.3 \\
\hline 12 & $(0.3$ & $(0.3)$ & 0.5 & 0.5 & $(0.9)$ & $(0$. & 0. & 0.0 & $(0.7)$ & $(0.7)$ & 0.3 & 0.3 & $(0.4)$ & $(0.4)$ & 0.7 & 0.7 \\
\hline 13 & $(0.3)$ & $\begin{array}{l}(0.3) \\
\end{array}$ & 0.5 & 0.5 & $(0.9)$ & $\begin{array}{l}(0.9) \\
\end{array}$ & 0.1 & 0.1 & (0.5) & $(0.5)$ & 0.6 & 0.6 & $(0.7)$ & $(0.7)$ & 0.3 & 0.3 \\
\hline 14 & $(0.5)$ & $(0.5)$ & 0.2 & 0.2 & (1.1) & (1.1) & $(0.2)$ & $(0.2)$ & (1.0) & (1.0) & $\begin{array}{c}(0.2) \\
\end{array}$ & $\begin{array}{c}(0.2) \\
\end{array}$ & (1.0) & $(1.0)$ & $\begin{array}{l}(0.1) \\
\end{array}$ & $\begin{array}{l}(0.1) \\
\end{array}$ \\
\hline 15 & (0.5) & $\begin{array}{l}(0.5) \\
\end{array}$ & 0.2 & 0.2 & $(0.9)$ & $(0.9)$ & $(0.0)$ & $(0.0)$ & $(1.0)$ & (1.0) & $(0.1)$ & $(0.1)$ & $(1.0)$ & $(1.0)$ & $(0.0)$ & $(0.0)$ \\
\hline 16 & $(0.5)$ & $(0.5)$ & 0.2 & 0.2 & $(0.6)$ & $(0.6)$ & 0.4 & 0.4 & $(0.0)$ & $(0.0)$ & 0.9 & 0.9 & $(0.6)$ & $(0.6)$ & 0.3 & 0.3 \\
\hline Houstor & 0.4 & 0.4 & 1.3 & 1.3 & (1.0) & $(1.0)$ & $(0.1)$ & $(0.1)$ & $(0.8)$ & $(0.8)$ & 0.1 & 0.1 & $(0.9)$ & $(0.9)$ & $(0.1)$ & $(0.1)$ \\
\hline $\begin{array}{l}\text { Phoenix } \\
\end{array}$ & 0.5 & 0.9 & 1. & 1.6 & $(0.4)$ & $(0.4)$ & 0. & 0.5 & $(0.9)$ & (0.9) & $\begin{array}{l}(0.1) \\
\end{array}$ & $\begin{array}{c}(0.1) \\
\end{array}$ & $(0.2)$ & $(0.2)$ & 0.7 & 0.7 \\
\hline Atlanta & $(0.0)$ & $\begin{array}{l}(0.0) \\
\end{array}$ & 0. & 0.7 & $(0.2)$ & $(0.2)$ & 0. & 0.8 & $(0.4)$ & $(0.4)$ & 0.7 & 0.7 & 0.0 & 0.0 & 0.9 & 0.9 \\
\hline Minnea & 0. & 0.4 & 0. & 0.8 & $(0.4)$ & $(0.4)$ & 0. & 0.6 & $(0.0)$ & $(0.0)$ & 10 & 1.0 & $(0.1)$ & $(0.1)$ & 8 & 0.8 \\
\hline Chica & 0. & 0.0 & 0. & 0.7 & $(0.4)$ & $(0.4)$ & 0 & 0.5 & $(0.1)$ & $(0.1)$ & 0.9 & 0.9 & $(0.9)$ & $(0.9)$ & 0.1 & 0.1 \\
\hline Wash DC & 0.0 & 0.0 & 0.7 & 0.7 & $(0.6)$ & $(0.6)$ & 0.4 & 0.4 & 0.0 & \begin{tabular}{l|l}
0.0 \\
\end{tabular} & 0.8 & 0.8 & $(0.3)$ & $(0.3)$ & 0.6 & 0.6 \\
\hline
\end{tabular}

Table 18.

Percentage Peak Demand Savings

Comparison to California Title-24-2005 Standard or ASHRAE 90.1-1999

EC with and without daylighting. Standard with no shade and no daylighting.

Window-to-wall ratio $=0.6$

\begin{tabular}{|c|c|c|c|c|c|c|c|c|c|c|c|c|c|c|c|c|}
\hline \multirow{2}{*}{\begin{tabular}{|c|} 
Zone \\
B Daylight?
\end{tabular}} & \multicolumn{4}{|l|}{ North } & \multicolumn{4}{|l|}{ East } & \multicolumn{4}{|l|}{ South } & \multicolumn{4}{|l|}{ West } \\
\hline & $\mathrm{N}$ & $\mathrm{N}$ & $\mathrm{N}$ & $\mathrm{N}$ & $\mathrm{N}$ & $\mathrm{N}$ & $\mathrm{N}$ & $\mathrm{N}$ & $\mathrm{N}$ & $\mathrm{N}$ & $\mathrm{N}$ & $\mathrm{N}$ & $\mathrm{N}$ & $\mathrm{N}$ & $\mathrm{N}$ & $\mathrm{N}$ \\
\hline B Shade? & $\mathrm{N}$ & $\mathrm{N}$ & $\mathrm{N}$ & $\mathrm{N}$ & $\mathrm{N}$ & $\mathrm{N}$ & $\mathrm{N}$ & $\mathrm{N}$ & $\mathrm{N}$ & $\mathrm{N}$ & $\mathrm{N}$ & $\mathrm{N}$ & $\mathrm{N}$ & $\mathrm{N}$ & $\mathrm{N}$ & $\mathrm{N}$ \\
\hline E Daylight? & $\mathrm{N}$ & $\mathrm{N}$ & $\mathrm{Y}$ & $\mathrm{Y}$ & $\mathrm{N}$ & $\mathrm{N}$ & $\mathrm{Y}$ & $\mathrm{Y}$ & $\mathrm{N}$ & $\mathrm{N}$ & $\mathrm{Y}$ & $\mathrm{Y}$ & $\mathrm{N}$ & $\mathrm{N}$ & $\mathrm{Y}$ & $\mathrm{Y}$ \\
\hline E Shade? & $\mathrm{N}$ & $\mathrm{N}$ & $\mathrm{N}$ & $\mathrm{N}$ & $\mathrm{N}$ & $\mathrm{N}$ & $\mathrm{N}$ & $\mathrm{N}$ & $\mathrm{N}$ & $\mathrm{N}$ & $\mathrm{N}$ & $\mathrm{N}$ & $\mathrm{N}$ & $\mathrm{N}$ & $\mathrm{N}$ & $\mathrm{N}$ \\
\hline \multicolumn{17}{|l|}{ Climate } \\
\hline 1 & 0.7 & 0.7 & 15.5 & 15.5 & 2.4 & 2.4 & 19.4 & 19.4 & (2.1) & (2.1) & 17.3 & 17.3 & (8.3) & (8.3) & 12.8 & 12.8 \\
\hline 2 & (8.9) & (8.9) & 10.5 & 10.5 & \begin{tabular}{|l|}
$(21.8)$ \\
\end{tabular} & (21.8) & (1.8) & $(1.8)$ & \begin{tabular}{|l|}
$(15.3)$ \\
\end{tabular} & (15.3) & 4.6 & 4.6 & (16.5) & \begin{tabular}{|l|}
$(16.5)$ \\
\end{tabular} & 3.0 & 3.0 \\
\hline 3 & 1.7 & 1.7 & 17.8 & 17.8 & (3.8) & (3.8) & 15.9 & 15.9 & 3.5 & 3.5 & 21.5 & 21.5 & 1.0 & 1.0 & 19.8 & 19.8 \\
\hline 4 & 4.0 & 4.0 & 19.8 & 19.8 & (6.4) & (6.4) & 12.1 & 12.1 & (7.8) & (7.8) & 11.9 & 11.9 & 0.3 & 0.3 & \begin{tabular}{|l|}
18.9 \\
\end{tabular} & 18.9 \\
\hline 5 & 2.9 & 2.9 & 20.1 & 20.1 & $(8.2)$ & $(8.2)$ & 12.1 & 12.1 & 2.0 & 2.0 & 20.4 & 20.4 & 5.8 & 5.8 & \begin{tabular}{|l|}
23.6 \\
\end{tabular} & 23.6 \\
\hline 6 & (1.3) & (1.3) & 16.2 & 16.2 & (14.0) & (14.0) & 5.7 & 5.7 & (7.3) & (7.3) & 12.0 & 12.0 & (5.5) & (5.5) & 14.2 & 14.2 \\
\hline 7 & 0.6 & 0.6 & 16.9 & 16.9 & $(1.9)$ & (1.9) & 17.3 & 17.3 & 0.8 & 0.8 & 19.6 & 19.6 & 2.2 & 2.2 & 20.7 & 20.7 \\
\hline 8 & (2.4) & (2.4) & 12.5 & 12.5 & (11.6) & (11.6) & 7.9 & 7.9 & \begin{tabular}{|l|l}
$(10.8)$ \\
\end{tabular} & (10.8) & 8.1 & 8.1 & (10.5) & (10.5) & 9.0 & 9.0 \\
\hline 9 & 2.2 & 2.2 & 11.9 & 11.9 & (14.0) & $(14.0)$ & 4.4 & 4.4 & $(6.7)$ & (6.7) & 10.4 & 10.4 & (4.8) & (4.8) & 13.3 & 13.3 \\
\hline 10 & (8.5) & (8.5) & 7.5 & 7.5 & (21.2) & (21.2) & $(0.7)$ & $(0.7)$ & $(19.0)$ & (19.0) & $(0.7)$ & $(0.7)$ & (15.6) & (15.6) & 4.4 & 4.4 \\
\hline 11 & \begin{tabular}{|l|}
$(11.7)$ \\
\end{tabular} & \begin{tabular}{|l|l|}
$(11.7)$ \\
\end{tabular} & 6.1 & 6.1 & $(9.5)$ & $(9.5)$ & 7.0 & 7.0 & (5.9) & (5.9) & 9.2 & 9.2 & $(9.0)$ & $(9.0)$ & 5.7 & 5.7 \\
\hline 12 & (7.5) & (7.5) & 11.4 & 11.4 & (18.1) & (18.1) & 1.0 & 1.0 & \begin{tabular}{|l|l}
$(13.9)$ \\
\end{tabular} & (13.9) & 5.3 & 5.3 & (7.7) & (7.7) & 12.2 & 12.2 \\
\hline 13 & (6.1) & (6.1) & 11.2 & 11.2 & \begin{tabular}{|l|}
$(15.9)$ \\
\end{tabular} & (15.9) & 1.2 & 1.2 & (8.5) & (8.5) & 10.4 & 10.4 & (12.0) & \begin{tabular}{|l|}
$(12.0)$ \\
\end{tabular} & 5.5 & 5.5 \\
\hline 14 & (12.3) & (12.3) & 5.2 & 5.2 & (19.4) & (19.4) & (3.8) & (3.8) & \begin{tabular}{|l|l}
$(18.2)$ \\
\end{tabular} & (18.2) & (3.4) & $(3.4)$ & (16.7) & (16.7) & (2.4) & (2.4) \\
\hline 15 & (11.9) & (11.9) & 4.4 & 4.4 & (16.1) & (16.1) & $(0.0)$ & $(0.0)$ & (15.7) & (15.7) & (1.5) & $(1.5)$ & (16.5) & (16.5) & $(0.5)$ & $(0.5)$ \\
\hline 16 & (13.7) & (13.7) & 4.1 & 4.1 & (9.8) & (9.8) & 6.3 & 6.3 & (0.6) & $(0.6)$ & 14.9 & 14.9 & (10.0) & \begin{tabular}{|l|}
$(10.0)$ \\
\end{tabular} & 4.9 & 4.9 \\
\hline Houston & 8.7 & 8.7 & 26.3 & 26.3 & (19.6) & (19.6) & (1.4) & (1.4) & \begin{tabular}{|l|l|}
$(16.9)$ \\
\end{tabular} & (16.9) & 1.4 & 1.4 & (18.3) & \begin{tabular}{|l|}
$(18.3)$ \\
\end{tabular} & (1.3) & (1.3) \\
\hline Phoenix & 14.6 & 14.6 & 27.2 & 27.2 & $(6.7)$ & (6.7) & 8.7 & 8.7 & (15.1) & (15.1) & $(0.8)$ & $\overline{(0.8)}$ & (3.0) & $(3.0)$ & 10.5 & 10.5 \\
\hline Atlanta & $(0.8)$ & $(0.8)$ & 16.3 & 16.3 & (3.9) & (3.9) & 14.6 & 14.6 & (6.6) & (6.6) & 13.2 & 13.2 & 0.2 & 0.2 & 16.8 & 16.8 \\
\hline Minneap & 8.2 & 8.2 & 18.5 & 18.5 & (7.5) & (7.5) & 11.8 & 11.8 & $(0.2)$ & $(0.2)$ & 19.1 & 19.1 & (2.0) & (2.0) & 15.6 & 15.6 \\
\hline Chicago & 0.8 & 0.8 & 16.2 & 16.2 & (8.6) & (8.6) & 10.6 & 10.6 & (1.7) & (1.7) & 17.9 & 17.9 & (17.9) & (17.9) & 2.0 & 2.0 \\
\hline Wash DC & 0.5 & 0.5 & 16.4 & 16.4 & (11.3) & (11.3) & 7.7 & 7.7 & 0.2 & 0.2 & 15.9 & 15.9 & (6.1) & (6.1) & 12.1 & 12.1 \\
\hline
\end{tabular}


Table 19.

Primary Annual Energy Use Savings ( $\mathrm{kBtu} / \mathrm{ft}^{2}$-floor-yr)

Comparison to best commercially available window (F). Baseline daylight and shading condition defined in table.

EC defined with daylight control as defined in Table. EC has no shading.

Window-to-wall ratio $=0.3$

\begin{tabular}{|c|c|c|c|c|c|c|c|c|c|c|c|c|c|c|c|c|}
\hline \multirow{2}{*}{\begin{tabular}{|c|} 
Zone \\
B Daylight? \\
\end{tabular}} & \multicolumn{4}{|l|}{ North } & \multicolumn{4}{|l|}{ East } & \multicolumn{4}{|l|}{ South } & \multicolumn{4}{|l|}{ West } \\
\hline & $\mathrm{N}$ & $\mathrm{N}$ & $\bar{Y}$ & $\bar{Y}$ & $\mathrm{~N}$ & $\mathrm{~N}$ & $\mathrm{Y}$ & $\mathrm{Y}$ & $\mathrm{N}$ & $\mathrm{N}$ & $\mathrm{Y}$ & $\mathrm{Y}$ & $\mathrm{N}$ & $\mathrm{N}$ & $\mathrm{Y}$ & $\mathrm{Y}$ \\
\hline B Shade? & $\mathrm{N}$ & $\mathrm{Y}$ & $\mathrm{N}$ & $\mathrm{Y}$ & $\mathrm{N}$ & $\mathrm{Y}$ & $\mathrm{N}$ & $\mathrm{Y}$ & $\mathrm{N}$ & $\mathrm{Y}$ & $\mathrm{N}$ & $\mathrm{Y}$ & $\mathrm{N}$ & $\mathrm{Y}$ & $\mathrm{N}$ & $\mathrm{Y}$ \\
\hline E Daylight? & $\mathrm{N}$ & $\mathrm{N}$ & $\mathrm{Y}$ & $\mathrm{Y}$ & $\mathrm{N}$ & $\mathrm{N}$ & $\mathrm{Y}$ & $\mathrm{Y}$ & $\mathrm{N}$ & $\mathrm{N}$ & $\mathrm{Y}$ & $\mathrm{Y}$ & $\mathrm{N}$ & $\mathrm{N}$ & $\mathrm{Y}$ & $\mathrm{Y}$ \\
\hline E Shade? & $\mathrm{N}$ & $\mathrm{N}$ & $\mathrm{N}$ & $\mathrm{N}$ & $\mathrm{N}$ & $\mathrm{N}$ & $\mathrm{N}$ & $\mathrm{N}$ & $\mathrm{N}$ & $\mathrm{N}$ & $\mathrm{N}$ & $\mathrm{N}$ & $\mathrm{N}$ & $\mathrm{N}$ & $\mathrm{N}$ & $\mathrm{N}$ \\
\hline \multicolumn{17}{|l|}{ Climate } \\
\hline 1 & (1.4) & (1.3) & 0.0 & 0.1 & 1.9 & 1.9 & 3.3 & 3.3 & 8.2 & 4.6 & 8.9 & 5.1 & 2.8 & 2.2 & 3.9 & 3.4 \\
\hline 2 & (2.3) & (1.9) & (1.1) & $(0.7)$ & 4.3 & 2.5 & 5.4 & 3.4 & 11.4 & 5.9 & 12.1 & 6.3 & 5.3 & 2.5 & 6.4 & 3.4 \\
\hline 3 & (1.7) & (1.6) & $(0.1)$ & $(0.0)$ & 4.0 & 2.8 & 5.4 & 4.1 & 10.5 & 7.4 & 11.0 & 7.8 & 4.6 & 3.0 & 5.8 & 4.1 \\
\hline 4 & $(2.0)$ & (1.9) & $(0.7)$ & $\begin{array}{l}(0.6) \\
\end{array}$ & 3.4 & 2.3 & 4.5 & 3.3 & 6.2 & 3.0 & 6.3 & 3.0 & 4.2 & 2.7 & 5.1 & 3.6 \\
\hline 5 & (2.5) & (2.1) & (1.0) & $(0.6)$ & 3.0 & 1.2 & 4.3 & 2.2 & 6.6 & 3.4 & 7.2 & 3.9 & 3.6 & 2.1 & 4.9 & 3.1 \\
\hline 6 & (1.1) & (1.0) & (1.2) & (1.1) & 3.8 & 3.4 & 2.9 & 2.5 & 7.1 & 4.1 & 5.3 & 2.1 & 5.6 & 3.7 & 4.3 & 2.4 \\
\hline 7 & (2.5) & (2.3) & (1.0) & $(0.8)$ & 1.2 & 0.6 & 2.6 & 1.8 & 4.8 & 2.0 & 5.3 & 2.3 & 2.8 & 1.1 & 3.9 & 2.1 \\
\hline 8 & (2.6) & (2.5) & (1.0) & $(0.9)$ & 1.7 & 1.2 & 3.1 & 2.6 & 5.4 & 1.8 & 5.8 & 2.1 & 2.9 & 1.9 & 4.0 & 3.0 \\
\hline 9 & (2.5) & (2.2) & (1.4) & $(1.0)$ & 3.7 & 1.3 & 4.8 & 2.3 & 7.7 & 3.0 & 8.3 & 3.4 & 3.6 & 1.9 & 4.6 & 2.7 \\
\hline 10 & (1.7) & (1.3) & (0.5) & $(0.2)$ & 4.5 & 2.7 & 5.4 & 3.6 & 8.9 & 4.5 & 9.4 & 4.9 & 5.1 & 2.6 & 6.0 & 3.2 \\
\hline 11 & (3.5) & (3.5) & (2.1) & $(2.0)$ & 4.9 & 1.7 & 6.1 & 2.8 & 10.0 & 6.5 & 10.4 & 6.9 & 4.0 & (1.2) & 5.6 & $(0.2)$ \\
\hline 12 & (2.6) & (2.3) & (1.2) & $(1.0)$ & 5.7 & 2.1 & 7.0 & 3.1 & 10.2 & 6.4 & 10.5 & 6.6 & 5.7 & 0.2 & 7.0 & 1.6 \\
\hline 13 & (2.7) & (2.3) & (1.2) & $(0.8)$ & 5.3 & 1.8 & 6.5 & 2.8 & 5.1 & 2.6 & 5.5 & 2.8 & 4.8 & 0.9 & 6.0 & 1.8 \\
\hline 14 & (3.5) & (3.3) & (1.8) & (1.6) & 4.7 & 0.4 & 6.0 & 1.6 & 5.4 & 1.4 & 5.6 & 1.6 & 3.7 & (0.7) & 5.1 & 0.4 \\
\hline 15 & (3.6) & (3.4) & (2.5) & (2.3) & 4.5 & 2.2 & 5.5 & 3.2 & 5.6 & 2.3 & 6.0 & 2.6 & 2.7 & 1.3 & 3.5 & 2.0 \\
\hline 16 & (2.9) & (2.8) & (1.1) & (1.1) & 5.8 & 2.2 & 7.0 & 3.3 & 8.7 & 4.7 & 8.8 & 4.6 & 4.1 & 0.1 & 5.8 & 1.1 \\
\hline Houston & (1.7) & (1.6) & (0.5) & $(0.4)$ & 1.5 & 0.1 & 2.5 & 0.9 & 2.4 & 0.8 & 3.1 & 1.5 & 1.4 & 0.5 & 2.3 & 1.4 \\
\hline Phoenix & (3.1) & (2.9) & (1.6) & $(1.4)$ & 4.1 & 0.4 & 5.1 & 1.3 & 4.7 & 1.3 & 5.1 & 1.7 & 3.2 & 0.5 & 4.7 & 1.9 \\
\hline Atlanta & (1.4) & (1.2) & $(0.3)$ & $(0.1)$ & 3.7 & 2.2 & 4.6 & 3.0 & 5.8 & 1.4 & 6.4 & 1.8 & 3.7 & 1.5 & 4.7 & 2.5 \\
\hline Minneap & $(2.4)$ & (2.3) & (1.3) & (1.1) & 5.2 & $(1.5)$ & 6.1 & $(1.0)$ & 6.0 & 4.3 & 6.0 & 4.5 & 3.2 & 1.6 & 4.9 & 2.6 \\
\hline Chicago & (1.8) & (1.8) & $(0.7)$ & $(0.6)$ & 4.6 & 2.2 & 5.5 & 3.1 & 5.9 & 4.4 & 6.0 & 4.6 & 3.2 & 2.7 & 4.1 & 3.7 \\
\hline Wash DC & $(2.2)$ & $(2.0)$ & (1.1) & $(0.9)$ & 4.4 & 0.8 & 5.3 & 1.4 & 10.5 & 5.5 & 11.1 & 5.9 & 3.0 & 1.3 & 4.1 & 2.7 \\
\hline
\end{tabular}

Table 20.

Percentage Primary Annual Energy Use Savings

Comparison to best commercially available window $(\mathrm{F})$. Baseline daylight and shading condition defined in table.

EC defined with daylight control as defined in Table. EC has no shading.

Window-to-wall ratio $=0.3$

\begin{tabular}{|c|c|c|c|c|c|c|c|c|c|c|c|c|c|c|c|c|}
\hline Zone & North & & & & East & & & & South & & & & West & & & \\
\hline B Daylight? & $\mathrm{N}$ & $\mathrm{N}$ & $\mathrm{Y}$ & $\mathrm{Y}$ & $\mathrm{N}$ & $\mathrm{N}$ & $\mathrm{Y}$ & $\mathrm{Y}$ & $\mathrm{N}$ & $\mathrm{N}$ & $\mathrm{Y}$ & $\mathrm{Y}$ & $\mathrm{N}$ & $\mathrm{N}$ & $\mathrm{Y}$ & $\mathrm{Y}$ \\
\hline B Shade? & $\mathrm{N}$ & $\mathrm{Y}$ & $\mathrm{N}$ & $\mathrm{Y}$ & $\mathrm{N}$ & $\mathrm{Y}$ & $\mathrm{N}$ & $\mathrm{Y}$ & $\mathrm{N}$ & $\mathrm{Y}$ & $\mathrm{N}$ & $\mathrm{Y}$ & $\mathrm{N}$ & $\mathrm{Y}$ & $\mathrm{N}$ & $\mathrm{Y}$ \\
\hline E Daylight? & $\mathrm{N}$ & $\mathrm{N}$ & $\mathrm{Y}$ & $\mathrm{Y}$ & $\mathrm{N}$ & $\mathrm{N}$ & $\mathrm{Y}$ & $\mathrm{Y}$ & $\mathrm{N}$ & $\mathrm{N}$ & $\mathrm{Y}$ & $\mathrm{Y}$ & $\mathrm{N}$ & $\mathrm{N}$ & $\mathrm{Y}$ & $\mathrm{Y}$ \\
\hline E Shade? & $\mathrm{N}$ & $\mathrm{N}$ & $\mathrm{N}$ & $\mathrm{N}$ & $\mathrm{N}$ & $\mathrm{N}$ & $\mathrm{N}$ & $\mathrm{N}$ & $\mathrm{N}$ & $\mathrm{N}$ & $\mathrm{N}$ & $\mathrm{N}$ & $\mathrm{N}$ & $\mathrm{N}$ & $\mathrm{N}$ & $\mathrm{N}$ \\
\hline Climate & & & & & & & & & & & & & & & & \\
\hline 1 & $(1.2)$ & $(1.2)$ & 0.0 & 0.1 & 1.5 & 1.5 & 3.1 & 3.1 & 6.0 & 3.4 & 7.9 & 4.7 & 2.1 & 1.7 & 3.6 & 3.1 \\
\hline 2 & (1.8) & (1.5) & (1.1) & $(0.7)$ & 2.9 & 1.7 & 4.2 & 2.7 & 7.2 & 3.8 & 9.1 & 4.9 & 3.5 & 1.7 & 5.1 & 2.8 \\
\hline 3 & $(1.4)$ & (1.3) & $(0.1)$ & $(0.0)$ & 2.9 & 2.1 & 4.7 & 3.6 & 7.2 & 5.2 & 9.1 & 6.7 & 3.3 & 2.2 & 5.0 & 3.7 \\
\hline 4 & (1.6) & (1.5) & $(0.7)$ & $(0.6)$ & 2.4 & 1.6 & 3.8 & 2.7 & 4.1 & 2.0 & 5.1 & 2.5 & 3.0 & 1.9 & 4.4 & 3.1 \\
\hline 5 & $(2.0)$ & (1.7) & (1.0) & $(0.6)$ & 2.1 & 0.9 & 3.7 & 2.0 & 4.5 & 2.4 & 6.0 & 3.3 & 2.6 & 1.5 & 4.2 & 2.8 \\
\hline 6 & $(0.8)$ & $(0.8)$ & (1.1) & $(1.0)$ & 2.6 & 2.3 & 2.4 & 2.0 & 4.6 & 2.7 & 4.1 & 1.7 & 3.7 & 2.5 & 3.5 & 1.9 \\
\hline 7 & (1.9) & $(1.7)$ & $(0.9)$ & $(0.7)$ & 0.8 & 0.4 & 2.1 & 1.5 & 3.1 & 1.3 & 4.2 & 1.9 & 1.9 & 0.8 & 3.2 & 1.8 \\
\hline 8 & $(2.0)$ & (1.9) & (0.9) & $(0.8)$ & 1.1 & 0.8 & 2.5 & 2.1 & 3.4 & 1.2 & 4.5 & 1.7 & 2.0 & 1.3 & 3.2 & 2.4 \\
\hline 9 & (1.9) & (1.6) & (1.3) & $(0.9)$ & 2.4 & 0.8 & 3.7 & 1.8 & 4.8 & 1.9 & 6.2 & 2.6 & 2.3 & 1.2 & 3.7 & 2.2 \\
\hline 10 & $(1.2)$ & $(1.0)$ & $(0.5)$ & $(0.2)$ & 2.9 & 1.7 & 4.2 & 2.8 & 5.4 & 2.8 & 6.9 & 3.7 & 3.3 & 1.7 & 4.7 & 2.6 \\
\hline 11 & $(2.6)$ & $(2.6)$ & (1.9) & (1.8) & 3.1 & 1.1 & 4.6 & 2.2 & 6.2 & 4.2 & 7.7 & 5.3 & 2.6 & $(0.8)$ & 4.2 & $(0.1)$ \\
\hline 12 & $(2.0)$ & (1.8) & (1.1) & $(0.9)$ & 3.7 & 1.4 & 5.4 & 2.5 & 6.5 & 4.2 & 8.2 & 5.3 & 3.7 & 0.1 & 5.5 & 1.3 \\
\hline 13 & $(2.0)$ & (1.7) & (1.1) & $(0.7)$ & 3.4 & 1.1 & 4.8 & 2.1 & 3.2 & 1.6 & 4.1 & 2.2 & 3.0 & 0.6 & 4.5 & 1.4 \\
\hline 14 & $(2.5)$ & $(2.4)$ & (1.6) & (1.4) & 2.8 & 0.3 & 4.2 & 1.1 & 3.2 & 0.9 & 4.0 & 1.2 & 2.2 & $(0.4)$ & 3.7 & 0.3 \\
\hline 15 & $(2.4)$ & (2.3) & $(2.0)$ & (1.9) & 2.6 & 1.3 & 3.7 & 2.2 & 3.1 & 1.3 & 4.0 & 1.8 & 1.6 & 0.8 & 2.4 & 1.4 \\
\hline 16 & (2.3) & $(2.3)$ & (1.1) & (1.0) & 3.9 & 1.5 & 5.6 & 2.7 & 5.9 & 3.2 & 7.2 & 3.9 & 2.8 & 0.1 & 4.7 & 0.9 \\
\hline Houston & (1.2) & (1.1) & $(0.5)$ & $(0.3)$ & 1.0 & 0.1 & 1.9 & 0.7 & 1.5 & 0.5 & 2.4 & 1.1 & 0.9 & 0.3 & 1.8 & 1.1 \\
\hline Phoenix & $(2.1)$ & $(2.0)$ & (1.3) & (1.1) & 2.3 & 0.2 & 3.4 & 0.9 & 2.7 & 0.7 & 3.4 & 1.1 & 1.9 & 0.3 & 3.2 & 1.3 \\
\hline Atlanta & (1.1) & $(0.9)$ & $(0.3)$ & $(0.1)$ & 2.4 & 1.4 & 3.6 & 2.4 & 3.7 & 0.9 & 5.0 & 1.5 & 2.5 & 1.0 & 3.8 & 2.0 \\
\hline Minneap & (1.8) & $(1.7)$ & (1.1) & $(1.0)$ & 3.3 & $(1.0)$ & 4.5 & $(0.8)$ & 4.0 & 2.9 & 4.8 & 3.6 & 2.1 & 1.1 & 3.8 & 2.1 \\
\hline Chicago & (1.4) & $(1.4)$ & $(0.6)$ & $(0.6)$ & 3.1 & 1.5 & 4.4 & 2.5 & 4.1 & 3.1 & 5.0 & 3.8 & 2.1 & 1.8 & 3.2 & 2.9 \\
\hline Wash DC & $(1.6)$ & $(1.5)$ & $(1.0)$ & $(0.8)$ & 2.9 & 0.5 & 4.2 & 1.1 & 6.9 & 3.7 & 8.7 & 4.8 & 2.0 & 0.9 & 3.3 & 2.2 \\
\hline
\end{tabular}


Table 21.

Primary Annual Energy Use Savings ( $\mathrm{kBtu} / \mathrm{ft}^{2}$-floor-yr)

Comparison to best commercially available window (F). Baseline daylight and shading condition defined in table.

EC defined with daylight control as defined in Table. EC has no shading.

Window-to-wall ratio $=0.6$

\begin{tabular}{|c|c|c|c|c|c|c|c|c|c|c|c|c|c|c|c|c|}
\hline Zone & North & & & & East & & & & South & & & & West & & & \\
\hline B Daylight? & $\mathrm{N}$ & $\mathrm{N}$ & $\bar{Y}$ & $\bar{Y}$ & $\mathrm{~N}$ & $\mathrm{~N}$ & $\bar{Y}$ & $\bar{Y}$ & $\mathrm{~N}$ & $\mathrm{~N}$ & $\mathrm{Y}$ & $\bar{Y}$ & $\mathrm{~N}$ & $\bar{N}$ & $\mathrm{Y}$ & $\mathrm{Y}$ \\
\hline B Shade? & $\mathrm{N}$ & $\bar{Y}$ & $\mathrm{~N}$ & $\mathrm{Y}$ & $\mathrm{N}$ & $\mathrm{Y}$ & $\mathrm{N}$ & $\bar{Y}$ & $\mathrm{~N}$ & $\mathrm{Y}$ & $\mathrm{N}$ & $\bar{Y}$ & $\mathrm{~N}$ & $\bar{Y}$ & $\mathrm{~N}$ & $\bar{Y}$ \\
\hline E Daylight? & $\mathrm{N}$ & $\mathrm{N}$ & $\mathrm{Y}$ & $\mathrm{Y}$ & $\mathrm{N}$ & $\mathrm{N}$ & $\mathrm{Y}$ & $\mathrm{Y}$ & $\mathrm{N}$ & $\mathrm{N}$ & $\mathrm{Y}$ & $\mathrm{Y}$ & $\mathrm{N}$ & $\mathrm{N}$ & $\mathrm{Y}$ & $\mathrm{Y}$ \\
\hline E Shade? & $\mathrm{N}$ & $\mathrm{N}$ & $\mathrm{N}$ & $\mathrm{N}$ & $\mathrm{N}$ & $\mathrm{N}$ & $\mathrm{N}$ & $\mathrm{N}$ & $\mathrm{N}$ & $\mathrm{N}$ & $\mathrm{N}$ & $\mathrm{N}$ & $\mathrm{N}$ & $\mathrm{N}$ & $\mathrm{N}$ & $\mathrm{N}$ \\
\hline Climate & & & & & & & & & & & & & & & & \\
\hline 1 & 2.7 & 2.8 & 3.0 & 3.1 & 16.2 & 4.3 & 17.1 & 4.5 & 30.6 & 18.1 & 31.1 & 17.7 & 18.2 & 5.3 & 20.2 & $\overline{5.0}$ \\
\hline 2 & 2.0 & 2.3 & 2.1 & 2.5 & 23.7 & 9.9 & 24.4 & 10.5 & 37.3 & 18.6 & 38.4 & 18.7 & 25.5 & 8.2 & 26.5 & 8.1 \\
\hline 3 & 1.9 & 2.0 & 2.1 & 2.2 & 20.4 & 7.9 & 21.3 & 8.5 & 30.8 & 22.3 & 31.5 & 22.6 & 21.1 & 12.0 & 22.2 & 12.3 \\
\hline 4 & 1.8 & 1.8 & 1.9 & 1.9 & 19.7 & 8.2 & 20.5 & 9.1 & 25.7 & 15.2 & 26.1 & 15.1 & 21.1 & 11.9 & 21.9 & 12.2 \\
\hline 5 & 1.7 & 2.1 & 2.0 & 2.4 & 21.8 & 0.5 & 23.0 & 0.3 & 30.0 & 19.4 & 30.8 & 19.3 & 22.9 & 10.8 & 24.4 & 10.9 \\
\hline 6 & 1.2 & 1.4 & 1.3 & 1.6 & 16.0 & 5.4 & 16.6 & 5.8 & 25.6 & 14.8 & 26.5 & 14.3 & 20.2 & 10.2 & 20.8 & 10.3 \\
\hline 7 & 1.7 & 1.8 & 1.9 & 2.0 & 16.1 & 7.4 & \begin{tabular}{|l|}
17.0 \\
\end{tabular} & 8.3 & 24.6 & 16.2 & 25.1 & 16.3 & 19.2 & 10.4 & 19.9 & 10.6 \\
\hline 8 & 1.3 & 1.4 & 1.5 & 1.6 & 17.4 & 6.6 & \begin{tabular}{|l|}
18.2 \\
\end{tabular} & 7.3 & 26.2 & 14.5 & 26.7 & 14.3 & 19.1 & 9.6 & 19.7 & 9.6 \\
\hline 9 & 2.4 & 2.7 & 2.5 & 3.0 & 23.0 & 6.7 & 24.2 & 7.2 & 33.7 & 13.5 & 34.8 & 13.2 & 23.2 & 10.7 & 24.3 & 10.5 \\
\hline 10 & 2.0 & 2.2 & 2.1 & 2.3 & 21.0 & 5.2 & 21.9 & 5.6 & 33.3 & 17.3 & 34.3 & 17.4 & 22.3 & 9.5 & 23.1 & 9.5 \\
\hline 11 & 0.5 & 0.5 & 0.7 & 0.7 & 24.7 & 12.9 & 25.4 & 13.8 & 31.1 & 21.0 & 31.3 & 21.0 & 24.9 & 8.3 & 26.2 & 8.2 \\
\hline 12 & 1.7 & 1.9 & 1.8 & 2.0 & 26.8 & 11.7 & 27.4 & 12.3 & 32.0 & 19.8 & 32.3 & 19.6 & 25.9 & 7.6 & 26.6 & 7.2 \\
\hline 13 & 1.9 & 2.4 & 2.1 & 2.7 & 27.5 & 9.7 & \begin{tabular}{|l|}
28.3 \\
\end{tabular} & 10.1 & 25.9 & 15.4 & 26.2 & 15.2 & 25.3 & 8.0 & 26.0 & 7.7 \\
\hline 14 & 0.5 & 0.7 & 0.8 & 1.0 & 24.4 & 8.3 & 25.0 & 9.1 & 25.6 & 14.3 & 25.6 & 14.0 & 23.6 & 7.2 & 24.7 & 7.0 \\
\hline 15 & 1.4 & 1.7 & 1.6 & 1.9 & 22.1 & 6.8 & \begin{tabular}{|l|}
22.7 \\
\end{tabular} & 7.1 & 27.0 & 15.6 & 27.3 & 15.5 & 20.0 & 8.6 & 20.3 & 8.5 \\
\hline 16 & $(0.3)$ & $(0.2)$ & $(0.2)$ & $(0.1)$ & 26.4 & 13.6 & \begin{tabular}{|l}
26.7 \\
\end{tabular} & 14.1 & 31.2 & 17.7 & 31.1 & 16.8 & 22.7 & 3.7 & 23.8 & 3.2 \\
\hline Houston & 2.7 & 3.1 & 3.2 & 3.5 & 16.0 & 4.8 & 16.8 & 5.0 & 17.9 & 12.6 & 18.6 & 13.3 & 14.8 & 5.5 & 15.4 & 5.5 \\
\hline Phoenix & 1.4 & 1.7 & 1.8 & 2.1 & 23.2 & 7.2 & 23.8 & 7.6 & 24.2 & 14.5 & 24.2 & 14.5 & 21.7 & 8.8 & 22.8 & 8.8 \\
\hline Atlanta & 3.4 & 3.5 & 3.7 & 3.9 & 20.3 & 11.0 & 20.9 & 11.7 & 24.8 & 11.8 & 25.3 & 11.7 & 19.8 & 9.3 & 20.5 & 8.5 \\
\hline Minneap & 0.7 & 0.9 & 0.7 & 1.0 & 27.4 & 7.6 & 28.0 & 7.7 & 23.2 & 18.1 & 22.8 & 17.8 & 22.5 & 7.1 & 24.1 & 7.1 \\
\hline Chicago & 1.9 & 2.1 & 2.1 & 2.3 & 20.4 & 9.1 & 20.7 & 9.3 & 23.2 & 16.0 & 22.9 & 15.5 & 16.6 & 1.3 & 16.8 & 0.9 \\
\hline Wash DC & 2.1 & 2.4 & 2.3 & 2.7 & 20.7 & 5.0 & 21.3 & 6.2 & 32.0 & 18.2 & 32.5 & 18.0 & 18.3 & 5.6 & 19.4 & 5.5 \\
\hline
\end{tabular}

Table 22.

Percentage Primary Annual Energy Use Savings

Comparison to best commercially available window $(\mathrm{F})$. Baseline daylight and shading condition defined in table.

EC defined with daylight control as defined in Table. EC has no shading.

Window-to-wall ratio $=0.6$

\begin{tabular}{|c|c|c|c|c|c|c|c|c|c|c|c|c|c|c|c|c|}
\hline \multirow{2}{*}{\begin{tabular}{|c|} 
Zone \\
B Daylight? \\
\end{tabular}} & \multicolumn{4}{|l|}{ North } & \multicolumn{4}{|l|}{ East } & \multicolumn{4}{|l|}{ South } & \multicolumn{4}{|l|}{ West } \\
\hline & $\mathrm{N}$ & $\mathrm{N}$ & $\mathrm{Y}$ & $\mathrm{Y}$ & $\mathrm{N}$ & $\mathrm{N}$ & $\mathrm{Y}$ & $\mathrm{Y}$ & $\mathrm{N}$ & $\mathrm{N}$ & $\mathrm{Y}$ & $\mathrm{Y}$ & $\mathrm{N}$ & $\mathrm{N}$ & $\mathrm{Y}$ & $\mathrm{Y}$ \\
\hline B Shade? & $\mathrm{N}$ & $\mathrm{Y}$ & $\mathrm{N}$ & $\mathrm{Y}$ & $\mathrm{N}$ & $\mathrm{Y}$ & $\mathrm{N}$ & $\mathrm{Y}$ & $\mathrm{N}$ & $\mathrm{Y}$ & $\mathrm{N}$ & $\mathrm{Y}$ & $\mathrm{N}$ & $\mathrm{Y}$ & $\mathrm{N}$ & $\mathrm{Y}$ \\
\hline E Daylight? & $\mathrm{N}$ & $\mathrm{N}$ & $\mathrm{Y}$ & $\mathrm{Y}$ & $\mathrm{N}$ & $\mathrm{N}$ & $\mathrm{Y}$ & $\mathrm{Y}$ & $\mathrm{N}$ & $\mathrm{N}$ & $\mathrm{Y}$ & $\mathrm{Y}$ & $\mathrm{N}$ & $\mathrm{N}$ & $\mathrm{Y}$ & $\mathrm{Y}$ \\
\hline E Shade? & $\mathrm{N}$ & $\mathrm{N}$ & $\mathrm{N}$ & $\mathrm{N}$ & $\mathrm{N}$ & $\mathrm{N}$ & $\mathrm{N}$ & $\mathrm{N}$ & $\mathrm{N}$ & $\mathrm{N}$ & $\mathrm{N}$ & $\mathrm{N}$ & $\mathrm{N}$ & $\mathrm{N}$ & $\mathrm{N}$ & $\mathrm{N}$ \\
\hline \multicolumn{17}{|l|}{ Climate } \\
\hline 1 & 2.3 & 2.4 & 3.2 & 3.3 & 10.7 & 3.1 & 13.4 & 3.9 & 17.9 & 11.5 & 21.3 & 13.3 & 11.4 & 3.6 & 14.7 & 4.1 \\
\hline 2 & 1.5 & 1.7 & 2.0 & 2.3 & 12.8 & 5.8 & 15.3 & 7.2 & 18.0 & 9.9 & 21.2 & 11.6 & 13.7 & 4.8 & 16.4 & 5.7 \\
\hline 3 & 1.5 & 1.6 & 2.2 & 2.3 & 12.6 & 5.3 & 15.7 & 6.9 & 17.5 & 13.3 & 21.1 & 16.1 & 13.1 & 7.9 & 16.5 & 9.9 \\
\hline 4 & 1.4 & 1.4 & 1.9 & 1.9 & 11.6 & 5.2 & 14.3 & 6.9 & 14.1 & 8.8 & 16.9 & 10.5 & 12.7 & 7.6 & 15.8 & 9.4 \\
\hline 5 & 1.4 & 1.7 & 2.0 & 2.4 & 12.8 & 0.3 & 15.8 & 0.2 & 16.6 & 11.4 & 20.0 & 13.5 & 14.0 & 7.1 & 17.8 & 8.8 \\
\hline 6 & 0.9 & 1.0 & 1.2 & 1.5 & 9.5 & 3.4 & 11.7 & 4.4 & 13.7 & 8.5 & 16.7 & 9.7 & 11.6 & 6.3 & 14.3 & 7.6 \\
\hline 7 & 1.3 & 1.3 & 1.8 & 1.9 & 9.8 & 4.8 & 12.5 & 6.5 & 13.7 & 9.4 & 16.5 & 11.4 & 11.5 & 6.5 & 14.2 & 8.1 \\
\hline 8 & 0.9 & 1.0 & 1.3 & 1.5 & 10.1 & 4.1 & 12.6 & 5.5 & 13.7 & 8.1 & 16.4 & 9.5 & 10.9 & 5.8 & 13.4 & 7.0 \\
\hline 9 & 1.7 & 2.0 & 2.3 & 2.7 & 12.7 & 4.1 & 15.5 & 5.2 & 16.7 & 7.4 & 19.8 & 8.6 & 13.0 & 6.5 & 15.9 & 7.6 \\
\hline 10 & 1.4 & 1.6 & 1.9 & 2.1 & 11.4 & 3.1 & 13.9 & 4.0 & 16.0 & 9.0 & 19.0 & 10.7 & 12.1 & 5.5 & 14.7 & 6.6 \\
\hline 11 & 0.4 & 0.4 & 0.6 & 0.6 & 12.9 & 7.2 & 15.3 & 8.9 & 15.7 & 11.2 & 18.3 & 13.1 & 12.9 & $\begin{array}{l}4.7 \\
\end{array}$ & 15.5 & 5.4 \\
\hline 12 & 1.3 & 1.4 & 1.7 & 1.8 & 14.2 & 6.7 & 16.8 & 8.3 & 16.6 & 11.0 & 19.5 & 12.8 & 13.9 & 4.5 & 16.5 & 5.1 \\
\hline 13 & 1.3 & 1.7 & 1.8 & 2.3 & 14.0 & 5.4 & 16.6 & 6.7 & 13.1 & 8.3 & 15.4 & 9.6 & 12.9 & 4.5 & 15.3 & 5.1 \\
\hline 14 & 0.4 & 0.5 & 0.7 & 0.8 & 11.9 & 4.4 & 14.1 & 5.7 & 12.3 & 7.3 & 14.4 & 8.4 & 11.8 & 3.9 & 14.2 & 4.5 \\
\hline 15 & 0.9 & 1.1 & 1.2 & 1.4 & 10.8 & 3.6 & 12.8 & 4.4 & 12.5 & 7.7 & 14.6 & 8.9 & 9.9 & 4.5 & 11.7 & 5.3 \\
\hline 16 & $(0.2)$ & $(0.1)$ & $(0.2)$ & $(0.1)$ & 14.0 & 7.8 & 16.3 & 9.3 & 16.6 & 10.1 & 19.2 & 11.4 & 12.2 & 2.2 & 14.6 & 2.2 \\
\hline Houston & 1.8 & 2.1 & 2.6 & 2.9 & 8.9 & 2.9 & 11.0 & 3.5 & 9.9 & 7.1 & 12.1 & 9.0 & 8.2 & 3.2 & 10.1 & 3.9 \\
\hline Phoenix & 0.9 & 1.0 & 1.4 & 1.6 & 11.4 & 3.8 & 13.5 & 4.8 & 11.6 & 7.3 & 13.5 & 8.5 & 10.7 & 4.7 & 13.1 & 5.5 \\
\hline Atlanta & 2.3 & 2.4 & 3.2 & 3.3 & 11.3 & 6.4 & 13.5 & 8.1 & 13.2 & 6.8 & 15.8 & 8.0 & 11.1 & 5.6 & 13.4 & 6.0 \\
\hline Minneap & 0.4 & 0.6 & 0.6 & 0.8 & 13.8 & 4.3 & 15.9 & 5.0 & 12.5 & 10.1 & 14.2 & 11.5 & 12.1 & 4.1 & 14.8 & 4.8 \\
\hline Chicago & 1.3 & 1.5 & 1.8 & 1.9 & 11.1 & 5.2 & 12.9 & 6.2 & 12.9 & 9.2 & 14.7 & 10.5 & 9.0 & 0.8 & 10.5 & 0.6 \\
\hline Wash DC & 1.4 & 1.7 & 1.9 & 2.2 & 11.3 & 3.0 & 13.3 & 4.3 & 16.8 & 10.3 & 19.6 & 11.9 & 10.2 & 3.4 & 12.6 & 3.9 \\
\hline
\end{tabular}


Table 23.

Peak Demand Savings (W/ft2)

Comparison to best commercially available window (F). Baseline daylight and shading condition defined in table.

EC defined with daylight control as defined in Table. EC has no shading.

Window-to-wall ratio $=0.3$

\begin{tabular}{|c|c|c|c|c|c|c|c|c|c|c|c|c|c|c|c|c|}
\hline \multirow{2}{*}{$\begin{array}{c}\text { Zone } \\
\text { B Daylight? }\end{array}$} & \multicolumn{4}{|l|}{ North } & \multicolumn{4}{|l|}{ East } & \multicolumn{4}{|l|}{ South } & \multicolumn{4}{|l|}{ West } \\
\hline & $\mathrm{N}$ & $\mathrm{N}$ & $\mathrm{Y}$ & $\mathrm{Y}$ & $\mathrm{N}$ & $\mathrm{N}$ & $\mathrm{Y}$ & $\mathrm{Y}$ & $\mathrm{N}$ & $\mathrm{N}$ & $\mathrm{Y}$ & $\mathrm{Y}$ & $\mathrm{N}$ & $\mathrm{N}$ & $\mathrm{Y}$ & $\mathrm{Y}$ \\
\hline B Shade? & $\mathrm{N}$ & $\mathrm{Y}$ & $\mathrm{N}$ & $\mathrm{Y}$ & $\mathrm{N}$ & $\mathrm{Y}$ & $\mathrm{N}$ & $\mathrm{Y}$ & $\mathrm{N}$ & $\mathrm{Y}$ & $\mathrm{N}$ & $\mathrm{Y}$ & $\mathrm{N}$ & $\mathrm{Y}$ & $\mathrm{N}$ & $\mathrm{Y}$ \\
\hline E Daylight? & $\mathrm{N}$ & $\mathrm{N}$ & $\mathrm{Y}$ & $\mathrm{Y}$ & $\mathrm{N}$ & $\mathrm{N}$ & $\mathrm{Y}$ & $\mathrm{Y}$ & $\mathrm{N}$ & $\mathrm{N}$ & $\mathrm{Y}$ & $\mathrm{Y}$ & $\mathrm{N}$ & $\mathrm{N}$ & $\mathrm{Y}$ & $\mathrm{Y}$ \\
\hline E Shade? & $\mathrm{N}$ & $\mathrm{N}$ & $\mathrm{N}$ & $\mathrm{N}$ & $\mathrm{N}$ & $\mathrm{N}$ & $\mathrm{N}$ & $\mathrm{N}$ & $\mathrm{N}$ & $\mathrm{N}$ & $\mathrm{N}$ & $\mathrm{N}$ & $\mathrm{N}$ & $\mathrm{N}$ & $\mathrm{N}$ & $\mathrm{N}$ \\
\hline \multicolumn{17}{|l|}{ Climate } \\
\hline 1 & $(0.1)$ & $(0.1)$ & $(0.0)$ & $(0.0)$ & 0.3 & 0.3 & 0.2 & 0.2 & 0.4 & 0.3 & 0.4 & 0.2 & 0.3 & 0.2 & 0.2 & 0.2 \\
\hline 2 & $(0.2)$ & $(0.2)$ & $(0.1)$ & $(0.1)$ & 0.4 & 0.2 & 0.3 & 0.2 & 1.0 & 0.5 & 0.8 & 0.4 & 0.5 & 0.1 & 0.2 & 0.1 \\
\hline 3 & $(0.2)$ & $(0.2)$ & $(0.1)$ & $(0.1)$ & 0.4 & 0.2 & 0.3 & 0.2 & 0.7 & 0.6 & 0.6 & 0.5 & 0.4 & 0.2 & 0.3 & 0.1 \\
\hline 4 & $(0.2)$ & $(0.2)$ & $(0.1)$ & $(0.1)$ & 0.3 & 0.1 & 0.3 & 0.2 & 0.5 & 0.2 & 0.4 & 0.1 & 0.4 & 0.3 & 0.3 & 0.2 \\
\hline 5 & $(0.1)$ & $(0.1)$ & $(0.0)$ & $(0.0)$ & 0.4 & 0.2 & 0.3 & 0.2 & 0.7 & 0.4 & 0.5 & 0.4 & 0.4 & 0.2 & 0.3 & 0.1 \\
\hline 6 & $(0.1)$ & $(0.1)$ & $(0.1)$ & $(0.1)$ & 0.3 & 0.3 & 0.2 & 0.2 & 0.5 & 0.1 & 0.4 & 0.1 & 0.4 & 0.2 & 0.3 & 0.1 \\
\hline 7 & $(0.1)$ & $(0.1)$ & $(0.0)$ & $(0.1)$ & 0.4 & 0.2 & 0.3 & 0.2 & 0.6 & 0.3 & 0.5 & 0.2 & 0.4 & 0.1 & 0.2 & 0.1 \\
\hline 8 & $(0.1)$ & $(0.1)$ & $(0.1)$ & $(0.1)$ & 0.3 & 0.3 & 0.2 & 0.2 & 0.5 & 0.2 & 0.3 & 0.1 & 0.3 & 0.3 & 0.1 & 0.1 \\
\hline 9 & $(0.1)$ & $(0.1)$ & $(0.1)$ & $(0.1)$ & 0.5 & 0.1 & 0.3 & 0.1 & 1.1 & 0.3 & 1.0 & 0.2 & 0.3 & 0.2 & 0.3 & 0.3 \\
\hline 10 & $(0.1)$ & $(0.1)$ & $(0.1)$ & $(0.1)$ & 0.6 & 0.3 & 0.3 & 0.2 & 1.1 & 0.4 & 0.8 & 0.2 & 0.4 & 0.0 & 0.3 & 0.1 \\
\hline 11 & $(0.2)$ & $(0.2)$ & $(0.2)$ & $(0.2)$ & 0.5 & 0.2 & 0.4 & 0.2 & 1.0 & 0.7 & 0.8 & 0.5 & 0.4 & $(0.2)$ & 0.4 & $(0.1)$ \\
\hline 12 & $(0.1)$ & $(0.1)$ & $(0.1)$ & $(0.1)$ & 0.5 & 0.2 & 0.4 & 0.1 & 0.8 & 0.4 & 0.6 & 0.3 & 0.5 & $(0.2)$ & 0.4 & $(0.0)$ \\
\hline 13 & $(0.1)$ & $(0.1)$ & $(0.1)$ & $(0.1)$ & 0.6 & 0.1 & 0.7 & 0.2 & 0.5 & 0.0 & 0.4 & 0.1 & 0.4 & $(0.0)$ & 0.5 & 0.0 \\
\hline 14 & $(0.2)$ & $(0.2)$ & $(0.1)$ & $(0.1)$ & 0.6 & 0.2 & 0.5 & 0.2 & 0.6 & 0.1 & 0.5 & 0.1 & 0.4 & $(0.2)$ & 0.5 & $(0.2)$ \\
\hline 15 & $(0.2)$ & $(0.2)$ & $(0.1)$ & $(0.1)$ & 0.6 & 0.3 & 0.5 & 0.3 & 1.0 & 0.1 & 0.9 & 0.1 & 0.5 & 0.3 & 0.4 & 0.3 \\
\hline 16 & $(0.1)$ & $(0.2)$ & $(0.1)$ & $(0.1)$ & 0.5 & 0.2 & 0.5 & 0.2 & 0.6 & 0.2 & 0.6 & 0.2 & 0.4 & 0.0 & 0.5 & 0.1 \\
\hline Houston & $(0.0)$ & $(0.0)$ & 0.0 & 0.0 & 0.4 & 0.1 & 0.3 & 0.1 & 0.6 & 0.2 & 0.5 & 0.2 & 0.4 & 0.2 & 0.3 & 0.2 \\
\hline Phoenix & $(0.1)$ & $(0.1)$ & $(0.1)$ & $(0.1)$ & 0.5 & 0.2 & 0.4 & 0.1 & 0.7 & 0.2 & 0.7 & 0.2 & 0.5 & 0.3 & 0.6 & 0.3 \\
\hline Atlanta & 0.0 & 0.0 & 0.0 & 0.0 & 0.4 & 0.3 & 0.3 & 0.2 & 0.4 & 0.1 & 0.3 & 0.1 & 0.5 & 0.2 & 0.4 & 0.2 \\
\hline Minneap & $(0.0)$ & $(0.1)$ & $(0.0)$ & $(0.0)$ & 0.5 & $(0.1)$ & 0.3 & $(0.1)$ & 0.4 & 0.4 & 0.3 & 0.2 & 0.3 & 0.2 & 0.2 & 0.1 \\
\hline Chicago & $(0.0)$ & $(0.0)$ & $(0.0)$ & $(0.0)$ & 0.4 & 0.3 & 0.3 & 0.2 & 0.5 & 0.4 & 0.4 & 0.3 & 0.2 & 0.2 & 0.2 & 0.2 \\
\hline Wash DC & $(0.1)$ & $(0.1)$ & $(0.0)$ & $(0.0)$ & 0.5 & 0.1 & 0.4 & 0.1 & 0.8 & 0.6 & 0.9 & 0.5 & 0.3 & 0.2 & 0.3 & 0.2 \\
\hline
\end{tabular}

Table 24.

Percentage Peak Demand Savings

Comparison to best commercially available window (F). Baseline daylight and shading condition defined in table.

EC defined with daylight control as defined in Table. EC has no shading.

Window-to-wall ratio $=0.3$

\begin{tabular}{|c|c|c|c|c|c|c|c|c|c|c|c|c|c|c|c|c|}
\hline \multirow{2}{*}{$\begin{array}{c}\text { Zone } \\
\text { B Daylight? }\end{array}$} & \multicolumn{4}{|l|}{ North } & \multicolumn{4}{|l|}{ East } & \multicolumn{4}{|l|}{ South } & \multicolumn{4}{|l|}{ West } \\
\hline & $\mathrm{N}$ & $\mathrm{N}$ & $\mathrm{Y}$ & $\mathrm{Y}$ & $\mathrm{N}$ & $\mathrm{N}$ & $\mathrm{Y}$ & $\mathrm{Y}$ & $\mathrm{N}$ & $\mathrm{N}$ & $\mathrm{Y}$ & $\mathrm{Y}$ & $\mathrm{N}$ & $\mathrm{N}$ & $\mathrm{Y}$ & $\mathrm{Y}$ \\
\hline B Shade? & $\mathrm{N}$ & $\mathrm{Y}$ & $\mathrm{N}$ & $\mathrm{Y}$ & $\mathrm{N}$ & $\mathrm{Y}$ & $\mathrm{N}$ & $\mathrm{Y}$ & $\mathrm{N}$ & $\mathrm{Y}$ & $\mathrm{N}$ & $\mathrm{Y}$ & $\mathrm{N}$ & $\mathrm{Y}$ & $\mathrm{N}$ & $\mathrm{Y}$ \\
\hline E Daylight? & $\mathrm{N}$ & $\mathrm{N}$ & $\mathrm{Y}$ & $\mathrm{Y}$ & $\mathrm{N}$ & $\mathrm{N}$ & $\mathrm{Y}$ & $\mathrm{Y}$ & $\mathrm{N}$ & $\mathrm{N}$ & $\mathrm{Y}$ & $\mathrm{Y}$ & $\mathrm{N}$ & $\mathrm{N}$ & $\mathrm{Y}$ & $\mathrm{Y}$ \\
\hline E Shade? & $\mathrm{N}$ & $\mathrm{N}$ & $\mathrm{N}$ & $\mathrm{N}$ & $\mathrm{N}$ & $\mathrm{N}$ & $\mathrm{N}$ & $\mathrm{N}$ & $\mathrm{N}$ & $\mathrm{N}$ & $\mathrm{N}$ & $\mathrm{N}$ & $\mathrm{N}$ & $\mathrm{N}$ & $\mathrm{N}$ & $\mathrm{N}$ \\
\hline \multicolumn{17}{|l|}{ Climate } \\
\hline 1 & (1.9) & (1.9) & (1.6) & (1.5) & 7.6 & 7.5 & 6.4 & 6.4 & 8.0 & 6.9 & 9.8 & 6.6 & 5.6 & 5.5 & 4.8 & 4.7 \\
\hline 2 & (4.7) & (4.6) & (2.4) & (2.2) & 8.0 & 4.1 & 7.4 & 4.6 & 17.6 & 8.9 & 16.8 & 8.1 & 9.1 & 3.0 & 4.6 & 3.1 \\
\hline 3 & $(5.1)$ & $(5.0)$ & $(3.4)$ & (3.3) & 9.6 & 5.3 & 8.4 & 4.7 & 15.1 & 12.0 & 14.0 & 11.4 & 8.3 & 4.8 & 7.2 & 3.9 \\
\hline 4 & $(7.0)$ & $(7.1)$ & $(4.1)$ & (4.1) & 6.3 & 1.9 & 7.1 & 4.1 & 10.6 & 4.8 & 8.5 & 3.6 & 8.2 & 5.8 & 7.4 & 5.3 \\
\hline 5 & $(4.0)$ & $(4.0)$ & $(1.2)$ & (1.5) & 7.9 & 4.6 & 6.9 & 4.1 & 13.6 & 8.2 & 12.3 & 8.8 & 8.9 & 5.3 & 7.3 & 3.6 \\
\hline 6 & $(2.5)$ & $(2.5)$ & $(2.7)$ & (2.7) & 6.3 & 5.5 & 5.0 & 4.2 & 9.6 & 2.7 & 9.1 & 3.0 & 7.9 & 3.6 & 6.2 & 2.3 \\
\hline 7 & (2.9) & (2.9) & $(1.2)$ & (1.6) & 8.9 & 4.9 & 8.4 & 4.8 & 11.7 & 6.0 & 11.4 & 5.8 & 9.3 & 3.2 & 6.0 & 2.4 \\
\hline 8 & (4.1) & (4.1) & (3.1) & (3.1) & 7.1 & 5.8 & 4.6 & 3.8 & 10.4 & 3.5 & 7.8 & 1.9 & 6.3 & 6.3 & 1.7 & 1.6 \\
\hline 9 & (2.1) & (2.7) & (2.0) & (2.7) & 8.7 & 2.0 & 6.2 & 2.2 & 17.7 & 5.9 & 18.2 & 5.1 & 6.8 & 4.6 & 6.6 & 5.7 \\
\hline 10 & $(2.6)$ & (2.5) & $(2.8)$ & (2.6) & 10.5 & 6.2 & 7.8 & 4.4 & 18.0 & 7.6 & 14.7 & 3.7 & 7.0 & 1.0 & 6.7 & 1.4 \\
\hline 11 & (5.1) & (5.2) & (5.0) & (5.1) & 9.2 & 4.5 & 7.9 & 3.6 & 16.8 & 12.2 & 15.9 & 11.3 & 7.2 & (3.3) & 8.4 & (3.1) \\
\hline 12 & $(3.0)$ & (3.0) & (2.6) & (2.5) & 8.9 & 3.1 & 8.7 & 3.4 & 15.4 & 8.1 & 13.1 & 7.4 & 8.9 & (3.4) & 9.4 & $(0.9)$ \\
\hline 13 & $(2.9)$ & (3.1) & (2.1) & (2.6) & 10.6 & 2.7 & 13.0 & 4.2 & 8.4 & 0.9 & 8.9 & 1.2 & 7.2 & $(0.8)$ & 9.5 & 0.8 \\
\hline 14 & $(4.8)$ & $(4.8)$ & (4.1) & (4.1) & 9.3 & 2.9 & 10.2 & 4.1 & \begin{tabular}{|l|}
10.1 \\
\end{tabular} & 2.4 & 9.2 & 2.3 & 6.9 & (4.3) & 9.6 & $(3.7)$ \\
\hline 15 & (3.8) & (3.9) & (2.3) & (3.5) & 10.7 & 6.1 & 10.2 & 5.0 & \begin{tabular}{|l|}
15.7 \\
\end{tabular} & 2.4 & 15.6 & 2.8 & 8.2 & 5.4 & 8.2 & 5.0 \\
\hline 16 & (4.0) & (4.1) & (2.6) & $(2.8)$ & 9.0 & 4.1 & 10.7 & 4.9 & \begin{tabular}{|l|}
11.7 \\
\end{tabular} & 4.8 & 12.4 & 5.6 & 6.3 & 0.2 & 9.2 & 1.5 \\
\hline Houston & $(0.2)$ & $(0.1)$ & 0.6 & 0.7 & 7.0 & 1.7 & 6.4 & 2.2 & \begin{tabular}{|l|}
11.0 \\
\end{tabular} & 4.6 & 9.8 & 4.9 & 6.8 & 4.2 & 6.1 & 3.4 \\
\hline Phoenix & (3.3) & (3.4) & (2.7) & (2.8) & 8.9 & 2.9 & 8.2 & 2.2 & \begin{tabular}{|l|}
10.7 \\
\end{tabular} & 2.7 & 11.9 & 3.5 & 8.2 & 4.4 & 10.5 & 6.0 \\
\hline Atlanta & 0.0 & 0.1 & 0.6 & 0.7 & 7.1 & 5.4 & 6.8 & 5.1 & 7.1 & 2.5 & 6.8 & 1.7 & 9.9 & 3.9 & 9.2 & 5.2 \\
\hline Minneap & (1.4) & (1.4) & (1.0) & $(1.0)$ & 8.7 & (1.6) & 6.9 & (2.2) & 8.6 & 7.9 & 7.0 & 6.2 & 6.9 & 4.6 & 5.7 & 3.6 \\
\hline Chicago & $(0.7)$ & $(0.8)$ & $(0.5)$ & $(0.5)$ & 8.6 & 5.4 & 7.2 & 4.3 & \begin{tabular}{|l|}
10.3 \\
\end{tabular} & 8.2 & 10.1 & 8.3 & 4.6 & 4.6 & 3.8 & 3.8 \\
\hline Wash DC & (1.7) & (1.7) & $(0.8)$ & $(0.7)$ & 9.0 & 2.1 & 8.4 & 2.6 & 15.3 & 11.3 & 18.4 & 10.9 & 6.5 & 3.3 & 6.5 & 4.5 \\
\hline
\end{tabular}


Table 25.

Peak Demand Savings (W/ft)

Comparison to best commercially available window (F). Baseline daylight and shading condition defined in table.

EC defined with daylight control as defined in Table. EC has no shading.

Window-to-wall ratio=0.6

\begin{tabular}{|c|c|c|c|c|c|c|c|c|c|c|c|c|c|c|c|c|}
\hline \multirow{2}{*}{\begin{tabular}{|c|} 
Zone \\
B Daylight? \\
\end{tabular}} & \multicolumn{4}{|l|}{ North } & \multicolumn{4}{|l|}{ East } & \multicolumn{4}{|l|}{ South } & \multicolumn{4}{|l|}{ West } \\
\hline & $\mathrm{N}$ & $\mathrm{N}$ & $\mathrm{Y}$ & $\mathrm{Y}$ & $\mathrm{N}$ & $\mathrm{N}$ & $\mathrm{Y}$ & $\mathrm{Y}$ & $\mathrm{N}$ & $\mathrm{N}$ & $\mathrm{Y}$ & $\mathrm{Y}$ & $\mathrm{N}$ & $\mathrm{N}$ & $\mathrm{Y}$ & $\mathrm{Y}$ \\
\hline B Shade? & $\mathrm{N}$ & $\mathrm{Y}$ & $\mathrm{N}$ & $\mathrm{Y}$ & $\mathrm{N}$ & $\mathrm{Y}$ & $\mathrm{N}$ & $\mathrm{Y}$ & $\mathrm{N}$ & $\mathrm{Y}$ & $\mathrm{N}$ & $\mathrm{Y}$ & $\mathrm{N}$ & $\mathrm{Y}$ & $\mathrm{N}$ & $\mathrm{Y}$ \\
\hline E Daylight? & $\mathrm{N}$ & $\mathrm{N}$ & $\mathrm{Y}$ & $\mathrm{Y}$ & $\mathrm{N}$ & $\mathrm{N}$ & $\mathrm{Y}$ & $\mathrm{Y}$ & $\mathrm{N}$ & $\mathrm{N}$ & $\mathrm{Y}$ & $\mathrm{Y}$ & $\mathrm{N}$ & $\mathrm{N}$ & $\mathrm{Y}$ & $\mathrm{Y}$ \\
\hline E Shade? & $\mathrm{N}$ & $\mathrm{N}$ & $\mathrm{N}$ & $\mathrm{N}$ & $\mathrm{N}$ & $\mathrm{N}$ & $\mathrm{N}$ & $\mathrm{N}$ & $\mathrm{N}$ & $\mathrm{N}$ & $\mathrm{N}$ & $\mathrm{N}$ & $\mathrm{N}$ & $\mathrm{N}$ & $\mathrm{N}$ & $\mathrm{N}$ \\
\hline \multicolumn{17}{|l|}{ Climate } \\
\hline 1 & 0.2 & 0.2 & 0.1 & 0.1 & 1.3 & 0.6 & 1.1 & 0.4 & 1.4 & 0.9 & 1.3 & 0.8 & 1.0 & 0.2 & 1.0 & 0.2 \\
\hline 2 & 0.1 & 0.1 & 0.1 & 0.1 & 1.5 & 0.8 & 1.5 & 0.8 & 2.5 & 1.4 & 2.5 & 1.4 & 1.5 & 0.4 & 1.5 & 0.4 \\
\hline 3 & 0.1 & 0.1 & 0.0 & 0.0 & 1.5 & 0.7 & 1.4 & 0.6 & 1.9 & 1.4 & 1.9 & 1.4 & 1.4 & 0.6 & 1.3 & 0.5 \\
\hline 4 & 0.1 & 0.1 & 0.1 & 0.1 & 1.5 & 0.8 & 1.5 & 0.8 & 1.6 & 0.9 & 1.6 & 0.9 & 1.4 & 0.7 & 1.3 & 0.7 \\
\hline 5 & 0.1 & 0.1 & 0.1 & 0.1 & 1.5 & 0.2 & 1.4 & 0.2 & 1.9 & 1.3 & 1.9 & 1.3 & 1.4 & 0.6 & 1.3 & 0.4 \\
\hline 6 & $(0.0)$ & $(0.0)$ & 0.0 & 0.0 & 1.2 & 0.4 & 1.2 & 0.4 & 1.5 & 0.9 & 1.5 & 0.9 & 1.3 & 0.5 & 1.3 & 0.5 \\
\hline 7 & 0.1 & 0.1 & 0.1 & 0.1 & 1.5 & 0.9 & 1.5 & 0.8 & 1.8 & 1.2 & 1.8 & 1.2 & 1.4 & 0.7 & 1.4 & 0.6 \\
\hline 8 & $(0.0)$ & $(0.0)$ & $(0.0)$ & $(0.0)$ & 1.4 & 0.6 & 1.4 & 0.6 & 1.7 & 0.7 & 1.7 & 0.8 & 1.1 & 0.5 & 1.2 & 0.5 \\
\hline 9 & 0.1 & 0.1 & 0.2 & 0.1 & 1.6 & 0.4 & 1.6 & 0.4 & 2.2 & 0.5 & 2.2 & 0.5 & 1.5 & 0.6 & 1.5 & 0.5 \\
\hline 10 & 0.1 & 0.1 & 0.1 & 0.1 & 1.5 & 0.6 & 1.5 & 0.6 & 2.4 & 1.0 & 2.4 & 1.0 & 1.5 & 0.5 & 1.5 & 0.6 \\
\hline 11 & 0.0 & 0.0 & 0.0 & 0.0 & 1.3 & 0.7 & 1.3 & 0.6 & 1.8 & 1.0 & 1.7 & 0.8 & 1.3 & 0.3 & 1.2 & 0.3 \\
\hline 12 & 0.1 & 0.1 & 0.1 & 0.1 & 1.5 & 0.7 & 1.5 & 0.7 & 2.0 & 1.0 & 2.0 & 0.9 & 1.6 & 0.4 & 1.6 & 0.4 \\
\hline 13 & 0.2 & 0.2 & 0.1 & 0.1 & 1.7 & 0.7 & 1.6 & 0.7 & 1.7 & 0.9 & 1.7 & 0.9 & 1.4 & 0.1 & 1.4 & 0.1 \\
\hline 14 & 0.0 & 0.0 & 0.0 & 0.0 & 1.4 & 0.5 & 1.3 & 0.4 & 1.4 & 0.5 & 1.2 & 0.3 & 1.2 & 0.3 & 1.2 & 0.3 \\
\hline 15 & 0.1 & 0.1 & $\begin{array}{ll}0.1 \\
\end{array}$ & 0.1 & 1.8 & 0.7 & 1.8 & 0.6 & 2.0 & 0.3 & 1.8 & 0.3 & 1.0 & 0.3 & 1.1 & 0.4 \\
\hline 16 & $(0.0)$ & $(0.0)$ & $(0.0)$ & $(0.0)$ & 1.4 & 0.8 & 1.3 & 0.8 & 0.7 & 0.5 & 0.7 & 0.5 & 0.8 & 0.2 & 0.8 & 0.1 \\
\hline Houston & 0.3 & 0.3 & 0.3 & 0.3 & 1.1 & 0.2 & 1.0 & 0.2 & 1.3 & 0.8 & 1.1 & 0.7 & 0.9 & 0.2 & 0.7 & 0.1 \\
\hline Phoenix & 0.1 & 0.1 & 0.1 & 0.1 & 1.4 & 0.6 & 1.4 & 0.6 & 1.1 & 0.2 & 0.9 & 0.2 & 0.9 & 0.3 & 1.0 & 0.3 \\
\hline Atlanta & 0.3 & 0.3 & 0.3 & 0.3 & 1.5 & 0.8 & 1.5 & 0.8 & 1.8 & 0.8 & 1.8 & 0.9 & 1.2 & 0.4 & 1.1 & 0.3 \\
\hline Minneap & 0.2 & 0.2 & 0.2 & 0.2 & 1.9 & 0.6 & 1.9 & 0.6 & 1.5 & 1.2 & 1.4 & 1.1 & 1.3 & 0.5 & 1.3 & 0.3 \\
\hline Chicago & 0.2 & 0.2 & 0.2 & 0.2 & 1.4 & 0.7 & 1.4 & 0.7 & 1.4 & 1.2 & 1.3 & 1.2 & 1.0 & $(0.0)$ & 1.0 & $(0.0)$ \\
\hline Wash DC & 0.3 & 0.3 & 0.2 & 0.2 & 1.4 & 0.3 & 1.4 & 0.3 & 2.1 & 0.9 & 1.9 & 0.7 & 1.3 & 0.4 & 1.2 & 0.3 \\
\hline
\end{tabular}

Table 26.

Percentage Peak Demand Savings

Comparison to best commercially available window (F). Baseline daylight and shading condition defined in table.

EC defined with daylight control as defined in Table. EC has no shading.

Window-to-wall ratio $=0.6$

\begin{tabular}{|c|c|c|c|c|c|c|c|c|c|c|c|c|c|c|c|c|}
\hline \multirow{2}{*}{$\begin{array}{c}\text { Zone } \\
\text { B Daylight? }\end{array}$} & \multicolumn{4}{|l|}{ North } & \multicolumn{4}{|l|}{ East } & \multicolumn{4}{|l|}{ South } & \multicolumn{4}{|l|}{ West } \\
\hline & $\mathrm{N}$ & $\mathrm{N}$ & $\mathrm{Y}$ & $\mathrm{Y}$ & $\mathrm{N}$ & $\mathrm{N}$ & $\mathrm{Y}$ & $\mathrm{Y}$ & $\mathrm{N}$ & $\mathrm{N}$ & $\mathrm{Y}$ & $\mathrm{Y}$ & $\mathrm{N}$ & $\mathrm{N}$ & $\mathrm{Y}$ & $\mathrm{Y}$ \\
\hline B Shade? & $\mathrm{N}$ & $\mathrm{Y}$ & $\mathrm{N}$ & $\mathrm{Y}$ & $\mathrm{N}$ & $\mathrm{Y}$ & $\mathrm{N}$ & $\mathrm{Y}$ & $\mathrm{N}$ & $\mathrm{Y}$ & $\mathrm{N}$ & $\mathrm{Y}$ & $\mathrm{N}$ & $\mathrm{Y}$ & $\mathrm{N}$ & $\mathrm{Y}$ \\
\hline E Daylight? & $\mathrm{N}$ & $\mathrm{N}$ & $\mathrm{Y}$ & $\mathrm{Y}$ & $\mathrm{N}$ & $\mathrm{N}$ & $\mathrm{Y}$ & $\mathrm{Y}$ & $\mathrm{N}$ & $\mathrm{N}$ & $\mathrm{Y}$ & $\mathrm{Y}$ & $\mathrm{N}$ & $\mathrm{N}$ & $\mathrm{Y}$ & $\mathrm{Y}$ \\
\hline E Shade? & $\mathrm{N}$ & $\mathrm{N}$ & $\mathrm{N}$ & $\mathrm{N}$ & $\mathrm{N}$ & $\mathrm{N}$ & $\mathrm{N}$ & $\mathrm{N}$ & $\mathrm{N}$ & $\mathrm{N}$ & $\mathrm{N}$ & $\mathrm{N}$ & $\mathrm{N}$ & $\mathrm{N}$ & $\mathrm{N}$ & $\mathrm{N}$ \\
\hline \multicolumn{17}{|l|}{ Climate } \\
\hline 1 & 5.0 & 5.2 & 3.5 & 3.7 & 22.8 & 11.9 & 22.1 & 9.6 & 21.4 & 14.9 & 23.9 & 15.7 & 15.9 & 3.2 & 19.0 & 3.6 \\
\hline 2 & 1.5 & 1.6 & 1.8 & 1.7 & 19.7 & 11.5 & 22.7 & 13.4 & 29.2 & 18.4 & 33.1 & 21.8 & 20.4 & 6.9 & 23.2 & 8.0 \\
\hline 3 & 2.0 & 2.0 & 1.5 & 1.5 & 22.8 & 12.1 & 26.0 & 13.7 & 27.8 & 22.3 & 31.1 & 24.9 & 21.6 & 11.3 & 24.3 & 11.8 \\
\hline 4 & 3.6 & 3.5 & 3.2 & 3.1 & 20.8 & 12.2 & 23.7 & 13.9 & 21.9 & 13.3 & 25.7 & 16.2 & 21.0 & 12.6 & 23.9 & 13.8 \\
\hline 5 & 2.2 & 2.9 & 2.8 & 2.7 & 21.1 & 3.4 & 24.5 & 3.5 & 27.2 & 20.3 & 30.7 & 22.9 & 22.4 & 10.7 & 25.4 & 9.8 \\
\hline 6 & $(0.2)$ & $(0.2)$ & 0.2 & 0.2 & 17.6 & 6.4 & 20.5 & 7.6 & 20.6 & 13.3 & 23.8 & 16.2 & 19.2 & 9.0 & 23.0 & 10.5 \\
\hline 7 & 1.4 & 1.5 & 1.5 & 1.6 & 22.6 & 14.6 & 25.9 & 16.7 & 25.0 & 17.8 & 28.8 & 21.0 & 21.7 & 12.0 & 24.9 & 13.5 \\
\hline 8 & $(0.5)$ & $(0.6)$ & $(0.3)$ & $(0.5)$ & 19.9 & 10.2 & 23.0 & 11.9 & 21.8 & 10.8 & 25.3 & 13.1 & 16.6 & 7.6 & 20.0 & 8.9 \\
\hline 9 & 2.7 & 2.8 & 4.2 & 3.9 & 20.9 & 5.6 & 24.0 & 7.7 & 25.4 & 7.2 & 29.0 & 9.0 & 21.8 & 9.2 & 24.8 & 10.2 \\
\hline 10 & 2.3 & 2.2 & 2.3 & 2.0 & 19.7 & 9.1 & 23.2 & 10.6 & 26.7 & 12.5 & 30.1 & 14.5 & 19.7 & 7.8 & 23.1 & 10.2 \\
\hline 11 & 0.5 & 0.3 & 0.5 & 0.3 & 17.8 & 9.9 & 19.5 & 10.6 & 23.1 & 14.3 & 24.4 & 14.0 & 16.7 & 5.1 & 18.2 & 5.7 \\
\hline 12 & 2.3 & 2.3 & 2.3 & 2.3 & 20.2 & 10.7 & 23.2 & 12.3 & 24.8 & 13.8 & 28.4 & 15.9 & 21.2 & 5.9 & 25.7 & 8.4 \\
\hline 13 & 3.5 & 3.4 & 3.6 & 3.5 & 21.0 & 9.7 & 23.0 & 11.0 & 22.4 & 13.0 & 25.8 & 15.6 & 18.3 & 1.3 & 21.0 & 1.1 \\
\hline 14 & 0.6 & 0.7 & 0.8 & 0.8 & 17.4 & 7.0 & 18.4 & 6.6 & 17.0 & 6.9 & 16.9 & 5.2 & 15.1 & 4.4 & 15.9 & 4.9 \\
\hline 15 & 1.8 & 1.6 & 2.0 & 1.9 & 21.1 & 8.9 & 23.6 & 9.8 & 21.5 & 4.1 & 22.4 & 4.9 & 12.4 & 4.7 & 15.2 & 5.9 \\
\hline 16 & $(0.3)$ & $(0.5)$ & (0.3) & $(0.5)$ & 17.4 & 10.5 & 19.4 & 12.9 & 10.2 & 7.1 & 11.5 & 9.3 & 11.4 & 3.1 & 12.9 & 2.3 \\
\hline Houston & 6.4 & 6.2 & 8.1 & 7.9 & 16.0 & 3.7 & 16.9 & 4.0 & 18.1 & 11.9 & 19.0 & 13.3 & 12.4 & 3.0 & 12.4 & 2.7 \\
\hline Phoenix & 2.6 & 2.5 & 2.1 & 2.1 & 17.6 & 8.6 & 20.3 & 9.9 & 13.3 & 3.2 & 12.8 & 3.7 & 12.1 & 4.7 & 14.7 & 5.1 \\
\hline Atlanta & 6.8 & 6.9 & 7.5 & 7.4 & 20.6 & 12.3 & 23.9 & 14.6 & 24.4 & 12.9 & 28.5 & 16.2 & 17.9 & 6.1 & 19.9 & 5.8 \\
\hline Minneap & 4.3 & 4.2 & 4.8 & 4.3 & 24.8 & 10.1 & 28.9 & 12.1 & 22.2 & 18.8 & 25.2 & 21.4 & 21.1 & 8.9 & 23.3 & 7.5 \\
\hline Chicago & 5.3 & 5.2 & 5.6 & 5.5 & 19.9 & 11.0 & 23.0 & 13.0 & 21.3 & 19.4 & 24.0 & 22.7 & 15.1 & $(0.3)$ & 17.6 & $(0.9)$ \\
\hline Wash DC & 5.9 & 5.7 & 5.9 & 5.7 & 19.8 & 4.8 & 23.0 & 6.7 & 28.2 & 15.1 & 29.4 & 14.0 & 18.5 & 6.2 & 21.4 & 6.6 \\
\hline
\end{tabular}


Table 27.

Primary Annual Energy Use Savings (kBtu/ $\mathrm{ft}^{2}$-floor-yr). Baseline with attached exterior shading.

Comparison to best commercially available window (F). Baseline daylight and shading condition defined in table.

EC defined with daylight control as defined in Table. EC has no shading.

Window-to-wall ratio $=0.3$

\begin{tabular}{|c|c|c|c|c|c|c|c|c|c|c|c|c|c|c|c|c|}
\hline Zone & North & & & & East & & & & South & & & & West & & & \\
\hline B Daylight? & $\mathrm{N}$ & $\mathrm{N}$ & $\mathrm{Y}$ & $\mathrm{Y}$ & $\mathrm{N}$ & $\mathrm{N}$ & $\mathrm{Y}$ & $\mathrm{Y}$ & $\mathrm{N}$ & $\mathrm{N}$ & $\mathrm{Y}$ & $\mathrm{Y}$ & $\mathrm{N}$ & $\mathrm{N}$ & $\bar{Y}$ & $\bar{Y}$ \\
\hline B Shade? & $\mathrm{N}$ & $\bar{Y}$ & $\mathrm{~N}$ & $\mathrm{Y}$ & $\mathrm{N}$ & $\bar{Y}$ & $\mathrm{~N}$ & $\mathrm{Y}$ & $\mathrm{N}$ & $\mathrm{Y}$ & $\mathrm{N}$ & $\mathrm{Y}$ & $\mathrm{N}$ & $\mathrm{Y}$ & $\mathrm{N}$ & $\bar{Y}$ \\
\hline \begin{tabular}{|l|} 
E Daylight? \\
\end{tabular} & $\mathrm{N}$ & $\mathrm{N}$ & $\mathrm{Y}$ & $\mathrm{Y}$ & $\mathrm{N}$ & $\mathrm{N}$ & $\mathrm{Y}$ & $\mathrm{Y}$ & $\mathrm{N}$ & $\mathrm{N}$ & $\mathrm{Y}$ & $\mathrm{Y}$ & $\mathrm{N}$ & $\mathrm{N}$ & $\mathrm{Y}$ & $\mathrm{Y}$ \\
\hline E Shade? & $\mathrm{N}$ & $\mathrm{N}$ & $\mathrm{N}$ & $\mathrm{N}$ & $\mathrm{N}$ & $\mathrm{N}$ & $\mathrm{N}$ & $\mathrm{N}$ & $\mathrm{N}$ & $\mathrm{N}$ & $\mathrm{N}$ & $\mathrm{N}$ & $\mathrm{N}$ & $\mathrm{N}$ & $\mathrm{N}$ & $\mathrm{N}$ \\
\hline Climate & & & & & & & & & & & & & & & & \\
\hline 1 & (4.3) & $(4.2)$ & $(0.1)$ & $(0.0)$ & \begin{tabular}{l|l}
$(10.6)$ \\
\end{tabular} & (10.5) & (3.4) & (3.4) & (0.8) & (2.3) & 2.2 & 0.6 & (11.7) & (11.7) & (4.6) & (4.6) \\
\hline 2 & (5.6) & $(5.4)$ & (1.1) & $(0.9)$ & (13.6) & $(14.0)$ & (7.9) & (8.3) & (3.0) & $(5.1)$ & $(0.9)$ & (3.1) & (12.3) & (12.3) & (6.8) & (6.8) \\
\hline 3 & (4.5) & (4.4) & 0.3 & 0.4 & (11.5) & (11.5) & (4.8) & (4.8) & $(2.1)$ & (2.6) & 0.0 & $(0.6)$ & (11.2) & (11.2) & (4.5) & (4.5) \\
\hline 4 & (5.3) & $\begin{array}{l}(5.3) \\
\end{array}$ & $(0.7)$ & $(0.6)$ & (13.0) & $(13.0)$ & (6.6) & $\begin{array}{l}(6.6) \\
\end{array}$ & $\begin{array}{l}(6.7) \\
\end{array}$ & $(7.4)$ & $\begin{array}{l}(4.8) \\
\end{array}$ & (5.6) & $(12.1)$ & (12.1) & $(5.7)$ & (5.7) \\
\hline 5 & (5.2) & \begin{tabular}{l|l}
$(4.8)$ \\
\end{tabular} & $(0.9)$ & $(0.5)$ & (11.9) & (11.9) & (5.7) & $\begin{array}{l}(5.7) \\
\end{array}$ & (5.3) & (6.1) & (3.2) & (4.1) & (11.6) & (11.6) & (5.3) & (5.3) \\
\hline 6 & (5.0) & $\begin{array}{ll}(4.2) \\
\end{array}$ & (1.1) & $(0.9)$ & $(12.0)$ & $(12.0)$ & $(7.4)$ & $(7.4)$ & (4.6) & (4.7) & $\begin{array}{l}(5.1) \\
\end{array}$ & $(5.2)$ & $(10.8)$ & (10.8) & $(7.1)$ & (7.1) \\
\hline 7 & (5.5) & $(5.4)$ & $(1.0)$ & $(0.8)$ & (12.6) & $(12.6)$ & (3.5) & (3.5) & (4.3) & (4.3) & $(2.6)$ & (2.6) & $(12.1)$ & $(12.1)$ & $(3.4)$ & (3.4) \\
\hline 8 & (5.6) & (5.5) & (0.9) & $(0.8)$ & $(13.0)$ & $(13.0)$ & (6.0) & $(6.0)$ & (7.2) & $(7.2)$ & (5.5) & (5.5) & $(12.6)$ & (12.6) & (6.5) & (6.5) \\
\hline 9 & (5.9) & $\begin{array}{l}(6.2) \\
\end{array}$ & (1.7) & (1.9) & (12.6) & $(12.6)$ & $(6.8)$ & $\begin{array}{l}(6.8) \\
\end{array}$ & $(5.0)$ & $(5.8)$ & (3.1) & $(4.0)$ & (11.8) & (11.8) & $(6.2)$ & (6.2) \\
\hline 10 & (5.9) & (5.7) & (1.7) & (1.5) & (14.1) & (14.1) & (8.3) & (8.3) & (4.7) & (5.3) & (3.0) & (4.9) & (12.4) & (12.4) & (7.1) & (7.1) \\
\hline 11 & (6.5) & $\begin{array}{ll}(6.3) \\
\end{array}$ & (1.6) & $(1.4)$ & (13.5) & (13.5) & (7.8) & $\begin{array}{l}(7.8) \\
\end{array}$ & $(4.2)$ & (4.7) & $\begin{array}{l}(2.6) \\
\end{array}$ & $(3.2)$ & (13.9) & (13.9) & $\begin{array}{l}(7.5) \\
\end{array}$ & (7.5) \\
\hline 12 & (6.0) & (5.9) & (0.9) & (0.5) & (13.9) & (13.9) & $(8.0)$ & $(8.0)$ & (4.2) & (4.6) & $(2.7)$ & (3.1) & $(12.0)$ & (12.0) & (6.1) & (6.1) \\
\hline 13 & (6.3) & $\begin{array}{ll}(6.1) \\
\end{array}$ & (1.5) & $(1.2)$ & (13.0) & $(13.0)$ & $(7.2)$ & $(7.2)$ & (8.8) & (9.1) & $\begin{array}{l}(6.6) \\
\end{array}$ & (6.9) & (11.6) & (11.6) & (6.1) & (6.1) \\
\hline 14 & (6.9) & $(6.7)$ & (1.5) & (1.2) & (16.1) & $(16.1)$ & $(10.2)$ & $(10.2)$ & $(9.0)$ & $(10.0)$ & $(7.8)$ & (8.9) & $(14.2)$ & (14.2) & $(8.2)$ & (8.2) \\
\hline 15 & $(7.2)$ & $\begin{array}{l}(7.0) \\
\end{array}$ & (2.9) & $(2.7)$ & \begin{tabular}{l|l}
$(14.1)$ \\
\end{tabular} & $(14.1)$ & $(9.0)$ & $(9.0)$ & $(7.0)$ & $(7.2)$ & (5.5) & $(5.8)$ & $(13.6)$ & (13.6) & $(8.8)$ & (8.8) \\
\hline 16 & (5.7) & $\begin{array}{l}(5.6) \\
\end{array}$ & $(0.6)$ & $(0.5)$ & (13.4) & $(13.4)$ & (7.5) & $(7.5)$ & (4.5) & $(7.1)$ & $(3.0)$ & (5.6) & $(14.4)$ & (14.4) & $(7.8)$ & $(7.7)$ \\
\hline Houston & (5.5) & (5.3) & (2.1) & $(2.0)$ & (11.4) & (11.4) & (5.6) & (5.6) & $\begin{array}{ll}(6.7) \\
\end{array}$ & (6.7) & (4.1) & (4.1) & (12.4) & (12.6) & (6.2) & (6.2) \\
\hline Phoenix & (6.8) & $(6.6)$ & (2.3) & $(2.2)$ & (13.8) & (13.9) & (8.9) & $(9.0)$ & $(6.2)$ & $(6.4)$ & (4.6) & $(4.9)$ & (11.0) & (12.1) & (5.1) & $(6.0)$ \\
\hline Atlanta & (5.0) & \begin{tabular}{l|l}
$(4.9)$ \\
\end{tabular} & (1.8) & (1.6) & (11.8) & (12.2) & (6.7) & $(7.1)$ & (6.2) & (6.3) & (4.1) & $(4.2)$ & (11.4) & (11.4) & (5.7) & (5.7) \\
\hline Minneap & (5.1) & $\begin{array}{l}(4.9) \\
\end{array}$ & (1.6) & $(1.4)$ & (11.6) & (12.4) & $(6.2)$ & $(7.0)$ & (4.5) & (5.9) & (2.6) & $(4.1)$ & $(9.2)$ & (9.7) & $(2.8)$ & (3.3) \\
\hline Chicago & (4.7) & (4.7) & (1.4) & (1.4) & (10.4) & $(10.7)$ & (5.0) & $(5.2)$ & (4.9) & (5.1) & (3.0) & (3.1) & (13.9) & (13.9) & (7.8) & (7.8) \\
\hline Wash DC & (5.1) & (5.0) & (2.1) & (1.9) & (10.1) & (10.1) & (4.6) & (4.6) & $(0.1)$ & (4.5) & 2.3 & (2.5) & (10.4) & (10.4) & (4.2) & (4.2) \\
\hline
\end{tabular}

Table 28.

Percentage Primary Annual Energy Use Savings. Baseline with attached exterior shading.

Comparison to best commercially available window (F). Baseline daylight and shading condition defined in table.

EC defined with daylight control as defined in Table. EC has no shading.

Window-to-wall ratio $=0.3$

\begin{tabular}{|c|c|c|c|c|c|c|c|c|c|c|c|c|c|c|c|c|}
\hline Zone & North & & & & East & & & & South & & & & West & & & \\
\hline B Daylight? & $\mathrm{N}$ & $\mathrm{N}$ & $\bar{Y}$ & $\mathrm{Y}$ & $\mathrm{N}$ & $\mathrm{N}$ & $\mathrm{Y}$ & $\mathrm{Y}$ & $\mathrm{N}$ & $\mathrm{N}$ & $\mathrm{Y}$ & $\mathrm{Y}$ & $\mathrm{N}$ & $\mathrm{N}$ & $\mathrm{Y}$ & $\mathrm{Y}$ \\
\hline B Shade? & $\mathrm{N}$ & $\bar{Y}$ & $\mathrm{~N}$ & $\mathrm{Y}$ & $\mathrm{N}$ & $\bar{Y}$ & $\mathrm{~N}$ & $\mathrm{Y}$ & $\mathrm{N}$ & $\mathrm{Y}$ & $\mathrm{N}$ & $\mathrm{Y}$ & $\mathrm{N}$ & $\mathrm{Y}$ & $\mathrm{N}$ & $\mathrm{Y}$ \\
\hline E Daylight? & $\mathrm{N}$ & $\mathrm{N}$ & $\mathrm{Y}$ & $\mathrm{Y}$ & $\mathrm{N}$ & $\mathrm{N}$ & $\mathrm{Y}$ & $\mathrm{Y}$ & $\mathrm{N}$ & $\mathrm{N}$ & $\mathrm{Y}$ & $\mathrm{Y}$ & $\mathrm{N}$ & $\mathrm{N}$ & $\mathrm{Y}$ & $\mathrm{Y}$ \\
\hline E Shade? & $\mathrm{N}$ & $\mathrm{N}$ & $\mathrm{N}$ & $\mathrm{N}$ & $\mathrm{N}$ & $\mathrm{N}$ & $\mathrm{N}$ & $\mathrm{N}$ & $\mathrm{N}$ & $\mathrm{N}$ & $\mathrm{N}$ & $\mathrm{N}$ & $\mathrm{N}$ & $\mathrm{N}$ & $\mathrm{N}$ & $\mathrm{N}$ \\
\hline Climate & & & & & & & & & & & & & & & & \\
\hline 1 & (3.8) & (3.7) & $(0.2)$ & $(0.0)$ & (9.1) & (9.1) & (3.4) & (3.4) & $\begin{array}{l}(0.7) \\
\end{array}$ & (1.8) & 2.1 & 0.6 & (10.0) & (10.0) & (4.6) & (4.6) \\
\hline 2 & (4.4) & (4.3) & (1.1) & $(0.9)$ & (10.2) & (10.5) & $(7.0)$ & $(7.4)$ & (2.1) & (3.6) & $(0.7)$ & $(2.7)$ & $(9.3)$ & (9.3) & $(6.0)$ & $(6.0)$ \\
\hline 3 & (3.8) & (3.7) & 0.3 & 0.4 & \begin{tabular}{l|}
$(9.4)$ \\
\end{tabular} & (9.4) & (4.6) & (4.6) & (1.5) & $(2.0)$ & 0.0 & $(0.5)$ & (9.1) & (9.1) & (4.4) & (4.4) \\
\hline 4 & (4.4) & (4.3) & $(0.7)$ & $(0.6)$ & (10.2) & $(10.2)$ & (6.1) & (6.1) & (4.9) & (5.4) & (4.2) & $(5.0)$ & (9.6) & (9.6) & (5.4) & (5.4) \\
\hline 5 & (4.4) & (4.1) & (0.9) & $(0.5)$ & (9.5) & (9.5) & (5.4) & (5.4) & (4.0) & (4.6) & (2.9) & (3.8) & (9.4) & (9.4) & (5.1) & (5.1) \\
\hline 6 & (4.0) & (3.3) & (1.0) & $(0.9)$ & (9.0) & $(9.0)$ & (6.6) & (6.6) & (3.2) & (3.2) & (4.3) & (4.4) & (8.1) & (8.1) & (6.2) & (6.2) \\
\hline 7 & (4.3) & $(4.2)$ & $(0.9)$ & $(0.8)$ & \begin{tabular}{l|}
$(9.6)$ \\
\end{tabular} & $(9.6)$ & $(3.0)$ & $(3.0)$ & (3.0) & $(3.0)$ & $(2.2)$ & $(2.2)$ & (9.1) & \begin{tabular}{l|}
$(9.1)$ \\
\end{tabular} & $(3.0)$ & $(3.0)$ \\
\hline 8 & (4.4) & (4.3) & (0.8) & $(0.7)$ & (9.7) & (9.7) & (5.3) & (5.3) & (4.9) & (5.0) & (4.6) & (4.6) & (9.3) & (9.3) & (5.7) & (5.7) \\
\hline 9 & (4.7) & (4.8) & (1.6) & $(1.8)$ & (9.2) & $(9.2)$ & (5.9) & (5.9) & (3.4) & $(4.0)$ & (2.6) & (3.3) & (8.6) & $\begin{array}{ll}(8.6) \\
\end{array}$ & (5.4) & (5.4) \\
\hline 10 & (4.5) & (4.4) & (1.6) & (1.4) & (10.3) & (10.3) & $(7.2)$ & $(7.2)$ & (3.1) & (3.5) & (2.4) & $(4.0)$ & (9.1) & (9.1) & (6.1) & (6.1) \\
\hline 11 & (5.0) & $(4.8)$ & $(1.4)$ & $(1.2)$ & $\begin{array}{l}(9.8) \\
\end{array}$ & $(9.8)$ & (6.6) & (6.6) & (2.9) & (3.3) & $(2.2)$ & $(2.6)$ & $(10.0)$ & $(10.0)$ & $(6.2)$ & $(6.2)$ \\
\hline 12 & $(4.7)$ & $\begin{array}{l}(4.6) \\
\end{array}$ & $(0.9)$ & $(0.5)$ & (10.4) & $(10.4)$ & $(7.0)$ & $(7.0)$ & (3.0) & (3.3) & (2.3) & $(2.7)$ & $(9.0)$ & $\begin{array}{l}(9.0) \\
\end{array}$ & $(5.4)$ & (5.4) \\
\hline 13 & (4.8) & $(4.6)$ & (1.4) & (1.1) & $(9.2)$ & $(9.2)$ & (5.9) & $(6.0)$ & $(6.0)$ & (6.2) & $(5.4)$ & (5.7) & $(8.2)$ & $(8.2)$ & (5.0) & $(5.0)$ \\
\hline 14 & (5.1) & $\begin{array}{l}(4.9) \\
\end{array}$ & (1.3) & $(1.0)$ & \begin{tabular}{l|l}
$(11.1)$ \\
\end{tabular} & (11.1) & $(8.1)$ & $(8.1)$ & (5.8) & (6.5) & (6.1) & $(7.0)$ & (9.8) & (9.8) & (6.5) & (6.5) \\
\hline 15 & (5.0) & (4.9) & (2.4) & $(2.2)$ & (9.1) & (9.1) & (6.7) & (6.7) & $(4.2)$ & (4.4) & $(4.0)$ & $(4.2)$ & (8.8) & (8.8) & (6.7) & (6.7) \\
\hline 16 & $(4.7)$ & (4.6) & $(0.6)$ & $(0.5)$ & (10.3) & $(10.3)$ & (6.7) & (6.7) & (3.4) & (5.3) & $(2.7)$ & $(5.2)$ & $(11.2)$ & $(11.2)$ & $(7.0)$ & $(7.0)$ \\
\hline Houston & (4.0) & (3.9) & (1.9) & (1.7) & (7.9) & $(7.9)$ & (4.5) & (4.5) & (4.5) & (4.5) & (3.3) & (3.3) & $(8.7)$ & (8.8) & (5.0) & (5.1) \\
\hline Phoenix & (4.7) & (4.6) & (1.9) & $(1.8)$ & \begin{tabular}{l|l}
$(8.9)$ \\
\end{tabular} & $(8.9)$ & (6.6) & $(6.8)$ & (3.7) & (3.9) & (3.3) & (3.6) & $(7.0)$ & (7.8) & (3.7) & (4.4) \\
\hline Atlanta & (3.8) & (3.7) & (1.6) & (1.5) & (8.7) & $(9.0)$ & (5.7) & (6.1) & (4.3) & (4.5) & (3.5) & (3.5) & (8.4) & (8.4) & (4.9) & (4.9) \\
\hline Minneap & (3.9) & (3.8) & (1.4) & (1.3) & (8.4) & $(9.0)$ & (5.1) & (5.8) & (3.2) & (4.3) & (2.3) & (3.5) & (6.8) & (7.1) & (2.3) & $(2.7)$ \\
\hline Chicago & (3.7) & (3.7) & (1.3) & (1.3) & (7.9) & $(8.0)$ & (4.3) & (4.5) & (3.6) & (3.8) & (2.7) & (2.8) & (10.6) & (10.6) & (6.7) & (6.7) \\
\hline Wash DC & $(4.0)$ & (3.9) & (1.9) & $(1.8)$ & (7.5) & $(7.4)$ & $(3.9)$ & (3.9) & $(0.1)$ & (3.3) & 1.9 & $(2.2)$ & $(7.7)$ & (7.7) & (3.6) & (3.5) \\
\hline
\end{tabular}


Table 29.

Primary Annual Energy Use Savings ( $\mathrm{kBtu} / \mathrm{ft}^{2}$-floor-yr). Baseline with attached exterior shading. Comparison to best commercially available window (F). Baseline daylight and shading condition defined in table. EC defined with daylight control as defined in Table. EC has no shading.

Window-to-wall ratio $=0.6$

\begin{tabular}{|c|c|c|c|c|c|c|c|c|c|c|c|c|c|c|c|c|}
\hline Zone & North & & & & East & & & & South & & & & West & & & \\
\hline B Daylight? & $\mathrm{N}$ & $\mathrm{N}$ & $\mathrm{Y}$ & $\mathrm{Y}$ & $\mathrm{N}$ & $\mathrm{N}$ & $\mathrm{Y}$ & $\mathrm{Y}$ & $\mathrm{N}$ & $\mathrm{N}$ & $\mathrm{Y}$ & $\mathrm{Y}$ & $\mathrm{N}$ & $\mathrm{N}$ & $\bar{Y}$ & $\bar{Y}$ \\
\hline B Shade? & $\mathrm{N}$ & $\mathrm{Y}$ & $\mathrm{N}$ & $\mathrm{Y}$ & $\mathrm{N}$ & $\mathrm{Y}$ & $\mathrm{N}$ & $\mathrm{Y}$ & $\mathrm{N}$ & $\mathrm{Y}$ & $\mathrm{N}$ & $\mathrm{Y}$ & $\mathrm{N}$ & $\mathrm{Y}$ & $\mathrm{N}$ & $\mathrm{Y}$ \\
\hline \begin{tabular}{|l|} 
E Daylight? \\
\end{tabular} & $\mathrm{N}$ & $\mathrm{N}$ & $\mathrm{Y}$ & $\mathrm{Y}$ & $\mathrm{N}$ & $\mathrm{N}$ & $\mathrm{Y}$ & $\mathrm{Y}$ & $\mathrm{N}$ & $\mathrm{N}$ & $\mathrm{Y}$ & $\mathrm{Y}$ & $\mathrm{N}$ & $\mathrm{N}$ & $\mathrm{Y}$ & $\mathrm{Y}$ \\
\hline E Shade? & $\mathrm{N}$ & $\mathrm{N}$ & $\mathrm{N}$ & $\mathrm{N}$ & $\mathrm{N}$ & $\mathrm{N}$ & $\mathrm{N}$ & $\mathrm{N}$ & $\mathrm{N}$ & $\mathrm{N}$ & $\mathrm{N}$ & $\mathrm{N}$ & $\mathrm{N}$ & $\mathrm{N}$ & $\mathrm{N}$ & $\mathrm{N}$ \\
\hline Climate & & & & & & & & & & & & & & & & \\
\hline 1 & $(2.2)$ & (2.1) & (1.0) & $(0.8)$ & (12.9) & (12.9) & (9.4) & $(9.4)$ & 11.7 & 5.9 & 13.4 & 6.9 & (13.1) & (22.0) & $(8.7)$ & (19.7) \\
\hline 2 & (3.3) & $(2.5)$ & $(2.2)$ & $(1.5)$ & (15.3) & $(15.3)$ & $(12.7)$ & $(12.7)$ & 7.7 & 0.6 & 9.2 & 1.6 & (13.1) & (16.1) & $(10.3)$ & (13.1) \\
\hline 3 & $(2.6)$ & $(2.4)$ & $(1.4)$ & $(1.2)$ & $(11.8)$ & $(11.8)$ & $(8.6)$ & $(8.7)$ & 7.0 & 5.1 & 8.3 & 6.2 & (10.3) & $(11.0)$ & $(7.0)$ & $(7.6)$ \\
\hline 4 & $(3.0)$ & $(2.9)$ & (1.9) & (1.7) & $(15.5)$ & (15.5) & $(13.0)$ & $(13.0)$ & 2.0 & $(0.8)$ & 2.9 & $(0.3)$ & $(11.7)$ & (12.5) & $(8.8)$ & $(9.6)$ \\
\hline 5 & (2.6) & $(2.4)$ & (1.1) & (0.8) & (14.7) & $(14.8)$ & (11.8) & (11.8) & 4.8 & 1.8 & 6.1 & 2.6 & (9.5) & $(10.7)$ & $(5.7)$ & (7.3) \\
\hline 6 & (3.8) & (3.6) & (2.6) & (2.4) & $(15.6)$ & (15.5) & (13.2) & $(13.2)$ & 1.6 & 0.4 & 2.7 & 1.1 & (12.6) & $(15.0)$ & (10.3) & (12.9) \\
\hline 7 & $(3.2)$ & $(3.0)$ & $(2.0)$ & (1.8) & (11.9) & (11.9) & $(8.9)$ & (8.9) & 2.6 & 2.7 & 3.6 & 3.6 & $(10.2)$ & $(12.1)$ & $(7.2)$ & (9.6) \\
\hline 8 & (3.8) & (3.6) & (2.6) & (2.3) & (16.1) & (16.1) & $(13.2)$ & $(13.2)$ & $\begin{array}{l}(0.1) \\
\end{array}$ & $(0.2)$ & 0.7 & 0.7 & (15.8) & (17.4) & (13.3) & $(15.2)$ \\
\hline 9 & (3.1) & $(2.7)$ & $(2.1)$ & (1.6) & $(12.7)$ & (12.6) & $(9.8)$ & (9.7) & 4.3 & 0.1 & 5.5 & 0.8 & $(10.2)$ & $(14.2)$ & $(7.7)$ & $(12.4)$ \\
\hline 10 & $(4.2)$ & $(4.0)$ & (3.2) & (3.0) & $(16.4)$ & $(16.4)$ & (13.5) & $(13.4)$ & 3.8 & 1.0 & 5.0 & 2.0 & (13.3) & (18.6) & $(11.1)$ & (16.9) \\
\hline 11 & $(4.4)$ & $(4.3)$ & (3.3) & (3.2) & $(13.0)$ & $(13.2)$ & (10.4) & (10.6) & 3.1 & 0.9 & 3.7 & 1.4 & (12.3) & $(21.4)$ & $(9.2)$ & (18.9) \\
\hline 12 & (3.6) & (3.3) & $(2.5)$ & (2.1) & $(15.0)$ & (15.1) & $(12.4)$ & $(12.4)$ & 4.2 & 2.3 & 4.9 & 2.9 & $(12.2)$ & $(15.6)$ & $(9.2)$ & (12.6) \\
\hline 13 & $(4.1)$ & (3.9) & $(3.0)$ & (2.7) & $(12.0)$ & (12.1) & (9.6) & (9.7) & (2.6) & (5.4) & $(2.3)$ & $(5.2)$ & $(12.2)$ & (17.3) & $(10.2)$ & $(15.2)$ \\
\hline 14 & (5.3) & $(5.0)$ & (3.9) & (3.6) & $(17.2)$ & $(17.2)$ & (14.8) & $(14.7)$ & (2.0) & $(5.2)$ & $(1.6)$ & $(5.0)$ & (14.1) & \begin{tabular}{|c|}
$(19.8)$ \\
\end{tabular} & $(11.6)$ & $(18.2)$ \\
\hline 15 & $(4.4)$ & $(4.0)$ & (3.5) & (3.1) & (12.9) & $(12.8)$ & $(10.6)$ & $(10.5)$ & 1.0 & 0.1 & 1.5 & 0.5 & $(12.7)$ & $(16.0)$ & $(11.3)$ & $(14.5)$ \\
\hline 16 & $(4.7)$ & $(4.6)$ & (3.6) & (3.5) & (12.8) & $(12.8)$ & (10.2) & $(10.2)$ & 5.6 & $(1.0)$ & 6.2 & $(0.7)$ & (14.7) & $(26.2)$ & (11.2) & (23.8) \\
\hline Houston & (3.2) & $(2.8)$ & (1.8) & (1.5) & $(10.2)$ & $(10.2)$ & (7.3) & (7.3) & 0.2 & 0.3 & 1.4 & 1.5 & $(11.7)$ & (13.5) & (8.6) & (10.5) \\
\hline Phoenix & $(4.6)$ & $(4.3)$ & $(3.0)$ & $(2.7)$ & $(9.5)$ & $(10.4)$ & $(7.0)$ & $(7.7)$ & 0.4 & $(0.5)$ & 0.7 & $(0.2)$ & (8.7) & (13.2) & $(5.8)$ & (11.0) \\
\hline Atlanta & $(2.4)$ & $(2.2)$ & (1.1) & $(0.8)$ & $(8.4)$ & $(10.5)$ & $(5.2)$ & $(7.5)$ & 0.8 & 0.3 & 1.6 & 1.2 & $(9.6)$ & (12.8) & $(7.3)$ & (11.3) \\
\hline Minneap & (3.5) & (3.3) & (2.3) & (2.1) & (6.6) & $(9.4)$ & (3.6) & (6.5) & 3.2 & (1.0) & 3.6 & $(0.5)$ & (1.6) & $(11.5)$ & 2.8 & (7.8) \\
\hline Chicago & $(2.7)$ & $(2.6)$ & (1.5) & (1.4) & (8.5) & $(10.3)$ & $(5.5)$ & $(7.3)$ & 1.6 & 1.4 & 2.1 & 2.1 & (13.5) & (25.3) & $(9.7)$ & $(22.2)$ \\
\hline Wash DC & $(3.2)$ & $(2.9)$ & $(2.0)$ & (1.7) & (6.3) & (6.3) & $(3.0)$ & $(2.9)$ & 10.9 & 0.2 & 12.2 & 0.7 & $(6.2)$ & $(10.9)$ & $(1.8)$ & $(7.3)$ \\
\hline
\end{tabular}

Table 30.

Percentage Primary Annual Energy Use Savings. Baseline with attached exterior shading.

Comparison to best commercially available window $(\mathrm{F})$. Baseline daylight and shading condition defined in table.

EC defined with daylight control as defined in Table. EC has no shading.

Window-to-wall ratio $=0.6$

\begin{tabular}{|c|c|c|c|c|c|c|c|c|c|c|c|c|c|c|c|c|}
\hline Zone & North & & & & East & & & & South & & & & West & & & \\
\hline B Daylight? & $\mathrm{N}$ & $\mathrm{N}$ & $\bar{Y}$ & $\mathrm{Y}$ & $\mathrm{N}$ & $\mathrm{N}$ & $\mathrm{Y}$ & $\mathrm{Y}$ & $\mathrm{N}$ & $\mathrm{N}$ & $\mathrm{Y}$ & $\mathrm{Y}$ & $\mathrm{N}$ & $\mathrm{N}$ & $\bar{Y}$ & $\bar{Y}$ \\
\hline B Shade? & $\mathrm{N}$ & $\bar{Y}$ & $\mathrm{~N}$ & $\mathrm{Y}$ & $\mathrm{N}$ & $\bar{Y}$ & $\mathrm{~N}$ & $\mathrm{Y}$ & $\mathrm{N}$ & $\mathrm{Y}$ & $\mathrm{N}$ & $\mathrm{Y}$ & $\mathrm{N}$ & $\mathrm{Y}$ & $\mathrm{N}$ & $\bar{Y}$ \\
\hline \begin{tabular}{|l|} 
E Daylight? \\
\end{tabular} & $\mathrm{N}$ & $\mathrm{N}$ & $\mathrm{Y}$ & $\mathrm{Y}$ & $\mathrm{N}$ & $\mathrm{N}$ & $\mathrm{Y}$ & $\mathrm{Y}$ & $\mathrm{N}$ & $\mathrm{N}$ & $\mathrm{Y}$ & $\mathrm{Y}$ & $\mathrm{N}$ & $\mathrm{N}$ & $\mathrm{Y}$ & $\mathrm{Y}$ \\
\hline E Shade? & $\mathrm{N}$ & $\mathrm{N}$ & $\mathrm{N}$ & $\mathrm{N}$ & $\mathrm{N}$ & $\mathrm{N}$ & $\mathrm{N}$ & $\mathrm{N}$ & $\mathrm{N}$ & $\mathrm{N}$ & $\mathrm{N}$ & $\mathrm{N}$ & $\mathrm{N}$ & $\mathrm{N}$ & $\mathrm{N}$ & $\mathrm{N}$ \\
\hline Climate & & & & & & & & & & & & & & & & \\
\hline 1 & (1.9) & (1.8) & (1.1) & $(0.9)$ & (10.5) & $(10.5)$ & (9.3) & (9.3) & 7.7 & 4.0 & 10.5 & 5.7 & (10.2) & $(18.4)$ & $(8.0)$ & (20.2) \\
\hline 2 & (2.5) & (1.9) & $(2.1)$ & $(1.4)$ & (10.5) & (10.5) & (10.3) & $(10.4)$ & 4.4 & 0.3 & 6.1 & 1.1 & $(8.9)$ & (11.1) & $(8.3)$ & (10.8) \\
\hline 3 & $(2.2)$ & \begin{tabular}{l|l}
$(2.0)$ \\
\end{tabular} & (1.5) & (1.3) & (9.1) & (9.1) & $(8.1)$ & $(8.2)$ & 4.6 & 3.4 & 6.6 & 5.0 & $(8.0)$ & $(8.6)$ & $(6.6)$ & (7.3) \\
\hline 4 & (2.4) & (2.3) & (1.9) & (1.8) & (11.5) & $(11.5)$ & (11.7) & $(11.8)$ & 1.2 & (0.5) & 2.2 & $(0.2)$ & (8.8) & (9.5) & (8.1) & (8.9) \\
\hline 5 & (2.1) & $\begin{array}{c}(1.9) \\
\end{array}$ & (1.1) & $(0.9)$ & (11.1) & (11.1) & (10.7) & (10.7) & 3.1 & 1.2 & \begin{tabular}{l|}
4.7 \\
\end{tabular} & 2.1 & $(7.2)$ & $(8.2)$ & (5.3) & (6.9) \\
\hline 6 & (2.9) & $\begin{array}{c}(2.7) \\
\end{array}$ & (2.5) & (2.3) & (11.3) & (11.3) & (11.8) & (11.8) & 1.0 & 0.2 & 2.0 & 0.8 & $(9.0)$ & (10.9) & (9.0) & (11.5) \\
\hline 7 & (2.5) & \begin{tabular}{l|l}
$(2.3)$ \\
\end{tabular} & (1.9) & $(1.7)$ & (8.8) & $(8.8)$ & $(8.1)$ & $(8.1)$ & 1.7 & 1.7 & 2.8 & 2.8 & (7.3) & (8.9) & $(6.4)$ & $(8.7)$ \\
\hline 8 & (2.9) & $(2.7)$ & (2.5) & $(2.2)$ & \begin{tabular}{l|l}
$(11.6)$ \\
\end{tabular} & $(11.6)$ & (11.7) & $(11.7)$ & $\begin{array}{ll}(0.1) \\
\end{array}$ & (0.1) & 0.5 & 0.5 & (11.3) & $(12.6)$ & $(11.6)$ & (13.6) \\
\hline 9 & (2.4) & $\begin{array}{l}(2.0) \\
\end{array}$ & (2.0) & (1.5) & (8.7) & $(8.7)$ & $(8.0)$ & $(8.0)$ & 2.5 & 0.0 & \begin{tabular}{l|}
3.7 \\
\end{tabular} & 0.6 & $(7.0)$ & $(10.0)$ & (6.4) & $(10.7)$ \\
\hline 10 & (3.1) & \begin{tabular}{c|}
$(3.0)$ \\
\end{tabular} & (3.0) & $(2.8)$ & (11.2) & (11.1) & (11.1) & $(11.0)$ & 2.1 & 0.5 & 3.3 & 1.3 & (9.0) & $(13.0)$ & (9.0) & (14.5) \\
\hline 11 & (3.1) & (3.1) & (2.9) & (2.8) & (8.4) & (8.6) & $(8.0)$ & $(8.2)$ & 1.9 & 0.5 & 2.6 & 1.0 & (7.9) & (14.5) & (6.9) & (15.3) \\
\hline 12 & $(2.7)$ & (2.5) & (2.4) & $(2.0)$ & \begin{tabular}{l|l}
$(10.2)$ \\
\end{tabular} & $(10.2)$ & (10.1) & $(10.1)$ & 2.5 & 1.4 & 3.5 & 2.1 & $(8.2)$ & $(10.8)$ & (7.4) & $(10.4)$ \\
\hline 13 & (3.0) & (2.8) & (2.7) & (2.4) & $(7.7)$ & (7.7) & (7.3) & (7.3) & (1.5) & (3.3) & $(1.6)$ & (3.7) & (7.7) & (11.3) & (7.7) & (11.8) \\
\hline 14 & (3.6) & (3.4) & (3.3) & (3.1) & \begin{tabular}{l|l}
$(10.6)$ \\
\end{tabular} & (10.5) & $(10.8)$ & (10.7) & (1.1) & (2.9) & (1.1) & (3.4) & (8.6) & $(12.6)$ & $(8.4)$ & (13.9) \\
\hline 15 & (2.8) & $\begin{array}{l}(2.6) \\
\end{array}$ & (2.8) & (2.4) & (7.6) & $(7.5)$ & $(7.4)$ & (7.3) & 0.5 & 0.1 & 0.9 & 0.3 & (7.5) & $(9.7)$ & (7.9) & (10.5) \\
\hline 16 & (3.6) & $\begin{array}{l}(3.5) \\
\end{array}$ & (3.4) & (3.3) & (8.6) & (8.6) & $(8.0)$ & (8.0) & 3.4 & $(0.6)$ & 4.5 & $(0.6)$ & (9.9) & $(19.1)$ & $(8.8)$ & (20.7) \\
\hline Houston & $(2.2)$ & (1.9) & (1.5) & $(1.2)$ & (6.7) & (6.7) & (5.7) & (5.7) & 0.1 & 0.2 & 1.0 & 1.1 & $(7.7)$ & (8.9) & (6.7) & (8.3) \\
\hline Phoenix & (3.0) & $(2.8)$ & $(2.4)$ & $(2.1)$ & (5.5) & (6.1) & (4.9) & (5.3) & 0.2 & $(0.3)$ & 0.4 & $(0.1)$ & (5.1) & $(7.9)$ & $(4.0)$ & (7.8) \\
\hline Atlanta & (1.7) & (1.6) & (0.9) & $(0.7)$ & (5.6) & $(7.0)$ & (4.1) & (5.9) & 0.5 & 0.2 & 1.2 & 0.9 & (6.4) & (8.8) & (5.8) & (9.3) \\
\hline Minneap & (2.4) & $(2.2)$ & (1.9) & (1.7) & (4.0) & (5.8) & (2.5) & (4.6) & 1.9 & $(0.6)$ & 2.6 & $(0.4)$ & (1.0) & $(7.6)$ & 2.0 & (5.9) \\
\hline Chicago & (1.9) & (1.8) & (1.3) & $(1.2)$ & (5.5) & (6.7) & (4.1) & (5.5) & 1.0 & 0.9 & 1.6 & 1.5 & (8.8) & $(17.7)$ & $(7.2)$ & (18.2) \\
\hline Wash DC & (2.3) & (2.1) & (1.8) & (1.5) & (4.0) & (4.0) & (2.2) & $(2.2)$ & 6.4 & 0.1 & 8.4 & 0.5 & (4.0) & (7.3) & (1.4) & (5.7) \\
\hline
\end{tabular}


Table 31.

Peak Demand Savings (W/ft2). Baseline with attached exterior shading.

Comparison to best commercially available window (F). Baseline daylight and shading condition defined in table.

EC defined with daylight control as defined in Table. EC has no shading.

Window-to-wall ratio $=0.3$

\begin{tabular}{|c|c|c|c|c|c|c|c|c|c|c|c|c|c|c|c|c|}
\hline Zone & North & & & & East & & & & South & & & & West & & & \\
\hline B Daylight? & $\mathrm{N}$ & $\mathrm{N}$ & $\mathrm{Y}$ & $\mathrm{Y}$ & $\mathrm{N}$ & $\mathrm{N}$ & $\mathrm{Y}$ & $\mathrm{Y}$ & $\mathrm{N}$ & $\mathrm{N}$ & $\mathrm{Y}$ & $\bar{Y}$ & $\mathrm{~N}$ & $\mathrm{~N}$ & $\bar{Y}$ & $\mathrm{Y}$ \\
\hline B Shade? & $\mathrm{N}$ & $\mathrm{Y}$ & $\mathrm{N}$ & $\mathrm{Y}$ & $\mathrm{N}$ & $\mathrm{Y}$ & $\mathrm{N}$ & $\mathrm{Y}$ & $\mathrm{N}$ & $\mathrm{Y}$ & $\mathrm{N}$ & $\mathrm{Y}$ & $\mathrm{N}$ & $\mathrm{Y}$ & $\mathrm{N}$ & $\mathrm{Y}$ \\
\hline E Daylight? & $\mathrm{N}$ & $\mathrm{N}$ & $\mathrm{Y}$ & $\mathrm{Y}$ & $\mathrm{N}$ & $\mathrm{N}$ & $\mathrm{Y}$ & $\mathrm{Y}$ & $\mathrm{N}$ & $\mathrm{N}$ & $\mathrm{Y}$ & $\mathrm{Y}$ & $\mathrm{N}$ & $\mathrm{N}$ & $\mathrm{Y}$ & $\mathrm{Y}$ \\
\hline E Shade? & $\mathrm{N}$ & $\mathrm{N}$ & $\mathrm{N}$ & $\mathrm{N}$ & $\mathrm{N}$ & $\mathrm{N}$ & $\mathrm{N}$ & $\mathrm{N}$ & $\bar{N}$ & $\mathrm{~N}$ & $\mathrm{~N}$ & $\mathrm{~N}$ & $\mathrm{~N}$ & $\mathrm{~N}$ & $\mathrm{~N}$ & $\mathrm{~N}$ \\
\hline \multicolumn{17}{|l|}{ Climate } \\
\hline 1 & $(0.2)$ & $(0.2)$ & $(0.1)$ & $\begin{array}{l}(0.1) \\
\end{array}$ & $(0.7)$ & $(0.7)$ & $(0.5)$ & $(0.5)$ & $(0.1)$ & $(0.2)$ & $(0.0)$ & $(0.1)$ & $(0.9)$ & $(0.9)$ & (0.6) & $(0.6)$ \\
\hline 2 & $(0.2)$ & $(0.2)$ & $(0.1)$ & $(0.1)$ & $(0.7)$ & $(0.7)$ & $(0.4)$ & $(0.5)$ & 0.2 & $(0.2)$ & 0.2 & $(0.0)$ & (0.6) & $(0.6)$ & (0.5) & $(0.5)$ \\
\hline 3 & $(0.3)$ & $(0.3)$ & $(0.1)$ & $(0.1)$ & $(0.6)$ & $(0.6)$ & $(0.4)$ & $(0.4)$ & $(0.0)$ & $(0.1)$ & $(0.0)$ & 10) & $(0.7)$ & $(0.7)$ & (0.5) & $(0.5)$ \\
\hline 4 & $(0.3)$ & (0.3) & $(0.1)$ & $\begin{array}{l}(0.1) \\
\end{array}$ & $(0.7)$ & $(0.7)$ & $(0.4)$ & $(0.4)$ & $(0.3$ & $(0.3)$ & (0.1) & $(0.1)$ & $(0.7)$ & $(0.7)$ & (0.5) & $(0.5)$ \\
\hline 5 & $(0.2)$ & $(0.2)$ & $(0.1)$ & $(0.1)$ & $(0.7)$ & $(0.7)$ & $(0.5)$ & $(0.5)$ & 0.0 & $(0.1)$ & 0.0 & $(0.0)$ & $(0.7)$ & $(0.7)$ & (0.5) & $(0.5)$ \\
\hline 6 & $(0.2)$ & $(0.2)$ & $(0.1)$ & $\begin{array}{l}(0.1) \\
\end{array}$ & $(0.8)$ & $(0.8)$ & $(0.6)$ & $(0.6)$ & $(0.4)$ & $(0.4)$ & $(0.1)$ & $(0.1)$ & (0.6) & $(0.6)$ & $(0.4)$ & $(0.4)$ \\
\hline 7 & $(0.2)$ & $(0.2)$ & $(0.1)$ & $(0.1)$ & $(0.6)$ & $(0.6)$ & (0.4) & $(0.4)$ & $(0.1)$ & $(0.1)$ & 0.1 & 0.1 & $(0.6)$ & $(0.6)$ & $(0.3)$ & $(0.3)$ \\
\hline 8 & $(0.2)$ & $(0.2)$ & $(0.2)$ & $(0.2)$ & $(0.7)$ & $(0.7)$ & $(0.5)$ & $(0.5)$ & $(0.2)$ & $(0.2)$ & $(0.2)$ & $(0.2)$ & $(0.8)$ & $(0.8)$ & (0.6) & $(0.6)$ \\
\hline 9 & $(0.2)$ & $(0.2)$ & $(0.2)$ & $(0.2)$ & $(0.7)$ & $(0.7)$ & $(0.5)$ & $(0.5)$ & 0.3 & $(0.1)$ & 0.4 & 0.0 & $(0.5)$ & $(0.5)$ & $(0.4)$ & $(0.4)$ \\
\hline 10 & $(0.2)$ & $(0.2)$ & $(0.2)$ & $\begin{array}{l}(0.2) \\
\end{array}$ & $(0.7)$ & $(0.7)$ & (0.5) & $(0.5)$ & 0.2 & $(0.1)$ & 0.0 & $(0.1)$ & (0.7) & $(0.7)$ & $(0.5)$ & $(0.5)$ \\
\hline 11 & $(0.3)$ & $(0.3)$ & $(0.2$ & $(0.2)$ & $(0.8)$ & $(0.8)$ & $(0.4)$ & $(0.4)$ & 0.0 & $(0.0)$ & 0.1 & 1 & $(1.0)$ & $(1.0)$ & $(0.5)$ & $(0.5)$ \\
\hline 12 & $(0.3)$ & $(0.3)$ & $(0.2)$ & $(0.1)$ & $(0.8)$ & $(0.8)$ & $(0.6)$ & $(0.6)$ & 0.0 & $(0.0)$ & 0.1 & 0 & $(0.7)$ & $(0.7)$ & $(0.5)$ & $(0.5)$ \\
\hline 13 & $(0.3)$ & (0.3) & $(0.2)$ & $\begin{array}{l}(0.2) \\
\end{array}$ & $(0.8)$ & $(0.8)$ & $(0.7)$ & $(0.7)$ & $(0.5)$ & (0.6) & $(0.3)$ & $(0.4)$ & $(0.8)$ & $(0.8)$ & (0.6) & $(0.6)$ \\
\hline 14 & $(0.3)$ & $(0.3)$ & $(0.2)$ & $(0.2)$ & $(0.9)$ & (0.9) & $(0.7)$ & $(0.7)$ & $(0.1)$ & $(0.4)$ & $(0.1)$ & $(0.3)$ & (1.0) & $(1.0)$ & $(0.7)$ & $(0.7)$ \\
\hline 15 & $(0.3)$ & $(0.3)$ & $(0.2)$ & $\begin{array}{l}(0.2) \\
\end{array}$ & $(0.7)$ & $(0.7)$ & $(0.5)$ & $(0.5)$ & 0.1 & $(0.0)$ & 0.1 & $(0.0)$ & $(0.8)$ & $(0.8)$ & (0.6) & $(0.6)$ \\
\hline 16 & $(0.3)$ & $(0.3)$ & $(0.2)$ & $(0.2)$ & $(0.9)$ & $(0.9)$ & $(0.6)$ & $(0.6)$ & $(0.0)$ & $(0.4)$ & 0.0 & $(0.2)$ & (1.1) & (1.1) & $(0.7)$ & $\begin{array}{l}0.7) \\
\end{array}$ \\
\hline Houston & $(0.2)$ & $(0.2)$ & $(0.1)$ & $(0.1)$ & (0.7) & $(0.7)$ & $(0.4)$ & $(0.4)$ & $(0.3)$ & $(0.3)$ & $(0.1)$ & $(0.1)$ & (1.0) & $(1.0)$ & $(0.7)$ & $(0.7)$ \\
\hline Phoenix & $(0.3)$ & $(0.3)$ & $(0.2)$ & $(0.2)$ & $(0.7)$ & $(0.7)$ & $(0.4)$ & $(0.5)$ & $(0.3)$ & $(0.3)$ & 0.0 & $(0.0)$ & $(0.6)$ & $(0.7)$ & $(0.3)$ & $(0.4)$ \\
\hline Atlanta & $(0.2)$ & $(0.2)$ & $(0.2$ & $\begin{array}{l}(0.2) \\
\end{array}$ & (0.7) & $(0.7)$ & $(0.4)$ & $(0.5)$ & $(0.3)$ & $(0.3)$ & $(0.2)$ & $(0.2)$ & (0.7) & $(0.7)$ & $(0.4)$ & $(0.4)$ \\
\hline Minneap & $(0.2)$ & $(0.2)$ & $(0.1)$ & $(0.1)$ & $(0.7)$ & $(0.7)$ & $(0.5)$ & $(0.5)$ & $(0.2)$ & $(0.2)$ & $(0.0)$ & $(0.1)$ & (0.6) & $(0.6)$ & (0.3) & $(0.3)$ \\
\hline Chicago & $(0.2)$ & $(0.2)$ & $(0$. & $(0.1)$ & (0.6) & $(0.6)$ & $(0.4)$ & $(0.4)$ & $(0.2)$ & $(0.2)$ & $(0.1)$ & $(0.1)$ & (1.0) & $(1.0)$ & $(0.6)$ & $(0.6)$ \\
\hline Wash DC & $(0.2)$ & $(0.2)$ & $(0.1)$ & $(0.1)$ & $(0.6)$ & (0.6) & $\begin{array}{l}(0.3) \\
\end{array}$ & $\begin{array}{c}(0.3) \\
\end{array}$ & 0.4 & $\begin{array}{c}(0.1) \\
\end{array}$ & 0.4 & $(0.0)$ & $(0.6)$ & $(0.6)$ & $(0.3)$ & $\begin{array}{l}(0.3) \\
\end{array}$ \\
\hline
\end{tabular}

Table 32.

Percentage Peak Demand Savings. Baseline with attached exterior shading.

Comparison to best commercially available window (F). Baseline daylight and shading condition defined in table.

EC defined with daylight control as defined in Table. EC has no shading.

Window-to-wall ratio $=0.3$

\begin{tabular}{|c|c|c|c|c|c|c|c|c|c|c|c|c|c|c|c|c|}
\hline Zone & North & & & & East & & & & South & & & & West & & & \\
\hline B Daylight? & $\mathrm{N}$ & $\mathrm{N}$ & $\mathrm{Y}$ & $\bar{Y}$ & $\mathrm{~N}$ & $\mathrm{~N}$ & $\mathrm{Y}$ & $\mathrm{Y}$ & $\mathrm{N}$ & $\mathrm{N}$ & $\mathrm{Y}$ & $\mathrm{Y}$ & $\mathrm{N}$ & $\mathrm{N}$ & $\mathrm{Y}$ & $\mathrm{Y}$ \\
\hline B Shade? & $\mathrm{N}$ & $\bar{Y}$ & $\mathrm{~N}$ & $\bar{Y}$ & $\mathrm{~N}$ & $\bar{Y}$ & $\mathrm{~N}$ & $\bar{Y}$ & $\bar{N}$ & $\overline{\mathrm{Y}}$ & $\mathrm{N}$ & $\overline{\mathrm{Y}}$ & $\bar{N}$ & $\overline{\mathrm{Y}}$ & $\mathrm{N}$ & $\overline{\mathrm{Y}}$ \\
\hline E Daylight? & $\mathrm{N}$ & $\mathrm{N}$ & $\mathrm{Y}$ & $\overline{\mathrm{Y}}$ & $\mathrm{N}$ & $\mathrm{N}$ & $\bar{Y}$ & $\mathrm{Y}$ & $\overline{\mathrm{N}}$ & $\mathrm{N}$ & $\mathrm{Y}$ & - & $\mathrm{N}$ & $\mathrm{N}$ & $\mathrm{Y}$ & $\mathrm{Y}$ \\
\hline E Shade? & $\bar{N}$ & $\mathrm{~N}$ & $\mathrm{~N}$ & $\bar{N}$ & $\mathrm{~N}$ & $\bar{N}$ & $\bar{N}$ & $\mathrm{~N}$ & $\sqrt{N}$ & $\mathrm{~N}$ & $\mathrm{~N}$ & $\overrightarrow{N N}$ & $\mathrm{~N}$ & $\mathrm{~N}$ & $\mathrm{~N}$ & $\mathrm{~N}$ \\
\hline Climate & & & & & & & & & & & & & & & & \\
\hline 1 & (7.0) & (7.0) & (3.9) & (3.8) & (20.8) & (20.8) & (16.4) & (16.3) & 2.5) & (5.7) & (0.6) & (3.9) & (26.6) & 26.6) & (19.8) & (19.8) \\
\hline 2 & (6.7) & (6.6) & (3.9) & (3.8) & (16.3) & (18.0) & (12.4) & (13.4) & 4.2 & (3.8) & 4.7 & (1.0) & (15.1) & (15.1) & (13.2) & (13.2) \\
\hline 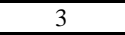 & .6) & (8.6) & (5.1) & (5.0) & (15.6) & (15.6) & (12.1) & (12.1) & $\begin{array}{l}(1.0) \\
\end{array}$ & (1.8) & $(0.7)$ & $(0.9)$ & (19.4) & (19.4) & $(15.2)$ & (15.2) \\
\hline 4 & .9 & (7.9) & (4.5) & (4.5) & (17.6) & (17.6) & (13.3) & (13.3) & (6. & $(7.3)$ & (2.4) & (3.3) & (20.5) & (20.5) & (16.8) & (16.8) \\
\hline 5 & 7.4) & (7.3) & (3.8) & $(4.0)$ & (18.2) & (18.2) & (14.4) & $(14$ & & (2.4) & 0.3 & (1. & (19.6) & (19.6) & (16.5) & (16.5) \\
\hline 6 & (6.5) & (6.1) & $(4.2)$ & (4.2) & $(21.2)$ & (21.2) & (17.2) & $(17.2)$ & $(8$. & (8.6) & (2.6) & (2.7) & (16.3) & $(1$ & (12.8) & (12.8) \\
\hline 7 & (6.1) & (6.0) & (3.7) & (3.9) & (16.5) & (16.5) & (13.4) & (13.4) & (1. & $(1.5)$ & 1.8 & 1.8 & $(15.2)$ & (15.2) & $(8.2)$ & $(8.2)$ \\
\hline 8 & (7.3) & $(7.2)$ & $(5.2)$ & $(5.2)$ & (19.3) & (19.3) & (15.2) & (15.2) & (4.9) & $(4.9)$ & (3.9) & (3.9) & $(20.4)$ & (20.4) & (18.7) & (18.7) \\
\hline$\overline{9}$ & (6.7) & $\begin{array}{l}(6.7) \\
\end{array}$ & (6.1) & $\begin{array}{l}(6.6) \\
\end{array}$ & (16.3) & (16.3) & (13.8) & (13.8) & 5 & (1.4) & 7.8 & 0.2 & (12.7) & (12.7) & (10.8) & (10.8) \\
\hline$\overline{11}$ & $5.8)$ & (6.8) & (5.1) & $(5.0)$ & (16.0) & (16.0) & (13.7) & (13.7) & & $(1.2)$ & 0.8 & (1.5) & (15.2) & (15.2) & $(11.8)$ & (11.8) \\
\hline 11 & .7) & (8.8) & (6.9) & $(7.0)$ & (18.5) & (18.5) & (11.4) & (11.4) & & $(0.7)$ & 2.5 & 6 & (21.8) & (21.8) & (13.1) & (13.1) \\
\hline$\sqrt{12}$ & (7.5) & (7.5) & (5.3) & (4.4) & (20.2) & (20.2) & (17.0) & (17.0) & 0.4 & $(0.5)$ & 1.6 & 6 & (17.0) & (17.0) & (13.2) & (13.2) \\
\hline 13 & (7.4) & (7.4) & $(5.7)$ & (5.7) & (19.4) & (19.4) & (17.4) & (17.4) & $(10.5)$ & (13.5) & $(8.0)$ & (10.1) & (17.6) & (17.6) & (14.7) & (14.7) \\
\hline 14 & (9.0) & (9.0) & (7.1) & $(7.0)$ & (20.7) & (20.7) & (17.3) & (17.3) & (2.7) & (8.5) & (2.6) & (7.4) & (21.3) & (21.3) & (16.7) & (16.7) \\
\hline 15 & (8.1) & (8.3) & $(6.7)$ & $(6.8)$ & (14.9) & (14.9) & (11.5) & (11.5) & 1. & $(0.9)$ & 2.6 & $(0.4)$ & $(16.3)$ & (16.3) & (12.9) & (12.9) \\
\hline 16 & (7.8) & (7.9) & (5.5) & (5.6) & (20.6) & (20.5) & (17.7) & (17.6) & $(0.8)$ & (8.4) & 0.5 & (6.3) & (25.4) & (25.4) & (19.1) & (19.1) \\
\hline Houston & (5.3) & (5.2) & (3.2) & (3.1) & (15.5) & (15.5) & (11.5) & (11.5) & (5.8) & (5.8) & (2.3) & (2.3) & (24.5) & (25.9) & (19.1) & (19.9) \\
\hline Phoenix & (7.8) & (7.8) & $(6.0)$ & (6.1) & (15.5) & (15.4) & (10.1) & $(10.4)$ & $(4)$. & (6.1) & 0.2 & $(0.8)$ & (11.3) & (15.1) & (6.1) & $(9.2)$ \\
\hline Atlanta & $(5.8)$ & (5.8) & $(5$. & $(5.0)$ & (16.6) & (17.9) & (11.8) & (13.0) & (6) & $(6.2)$ & (3.8) & (3.7) & (17.7) & (17.7) & (10.3) & (10.3) \\
\hline Minneap & (6.0) & $(6.0)$ & (4.3) & (4.3) & (16.7) & (18.6) & $\begin{array}{l}(14.0) \\
\end{array}$ & (15.2) & (4.3) & (5.8) & $(0.6)$ & (4.2) & (14.5) & (15.6) & (7.8) & (8.8) \\
\hline Chicas & $(5.7$ & (5.7) & (3.7) & (3.6) & (15.0) & (15.5) & (10.1) & (10.5) & $(4)$. & (4.4) & (2.4) & (2.9) & (25.8) & (25.8) & (17.4) & (17.4) \\
\hline Wash DC & (6.1) & (6.0) & (3.9) & (3.7) & (13.8) & (13.8) & (6.7) & (6.6) & 7.3 & (2.7) & 9.3 & $(0.6)$ & (15.4) & (15.4) & (6.9) & (6.8) \\
\hline
\end{tabular}


Table 33.

Peak Demand Savings (W/ft). Baseline with attached exterior shading.

Comparison to best commercially available window (F). Baseline daylight and shading condition defined in table.

EC defined with daylight control as defined in Table. EC has no shading.

Window-to-wall ratio=0.6

\begin{tabular}{|c|c|c|c|c|c|c|c|c|c|c|c|c|c|c|c|c|}
\hline Zone & North & & & & East & & & & South & & & & West & & & \\
\hline B Daylight? & $\mathrm{N}$ & $\mathrm{N}$ & $\mathrm{Y}$ & $\bar{Y}$ & $\mathrm{~N}$ & $\mathrm{~N}$ & $\mathrm{Y}$ & $\bar{Y}$ & $\mathrm{~N}$ & $\mathrm{~N}$ & $\mathrm{Y}$ & $\mathrm{Y}$ & $\mathrm{N}$ & $\mathrm{N}$ & $\mathrm{Y}$ & $\mathrm{Y}$ \\
\hline B Shade? & $\mathrm{N}$ & $\mathrm{Y}$ & $\mathrm{N}$ & $\mathrm{Y}$ & $\mathrm{N}$ & $\mathrm{Y}$ & $\mathrm{N}$ & $\mathrm{Y}$ & $\mathrm{N}$ & $\mathrm{Y}$ & $\mathrm{N}$ & $\mathrm{Y}$ & $\mathrm{N}$ & $\begin{array}{l}\mathrm{Y} \\
\end{array}$ & $\mathrm{N}$ & $\mathrm{Y}$ \\
\hline E Daylight? & $\mathrm{N}$ & $\mathrm{N}$ & $\mathrm{Y}$ & $\mathrm{Y}$ & $\mathrm{N}$ & $\mathrm{N}$ & $\mathrm{Y}$ & $\mathrm{Y}$ & $\mathrm{N}$ & $\mathrm{N}$ & $\mathrm{Y}$ & $\mathrm{Y}$ & $\mathrm{N}$ & $\mathrm{N}$ & $\mathrm{Y}$ & $\mathrm{Y}$ \\
\hline E Shade? & $\mathrm{N}$ & $\mathrm{N}$ & $\mathrm{N}$ & $\mathrm{N}$ & $\mathrm{N}$ & $\mathrm{N}$ & $\mathrm{N}$ & $\mathrm{N}$ & $\mathrm{N}$ & $\mathrm{N}$ & $\mathrm{N}$ & $\mathrm{N}$ & $\mathrm{N}$ & $\mathrm{N}$ & $\mathrm{N}$ & $\mathrm{N}$ \\
\hline \multicolumn{17}{|l|}{ Climate } \\
\hline 1 & (0.1) & $\begin{array}{l}(0.1) \\
\end{array}$ & $(0.1)$ & $\begin{array}{l}(0.1) \\
\end{array}$ & $(0.7)$ & $(0.7)$ & $(0.5)$ & $(0.5)$ & 0.5 & 0.2 & 0.4 & 0.1 & (1.1) & (1.6) & (0.6) & $(1.2)$ \\
\hline 2 & $(0.1)$ & $(0.1)$ & $(0.1)$ & $(0.1)$ & $(0.8)$ & $(0.8)$ & $(0.7)$ & $(0.7)$ & 1.1 & 0.4 & 1.1 & 0.4 & $(0.8)$ & $(1.0)$ & (0.6) & $(0.8)$ \\
\hline 3 & $(0.1)$ & $(0.1)$ & $(0.1)$ & $(0.1)$ & $(0.5)$ & $(0.5)$ & $(0.4)$ & $(0.4)$ & 0.5 & 0.5 & 0.4 & 4 & $(0.9)$ & $(0.9)$ & $(0.5)$ & $(0.5)$ \\
\hline 4 & (0.1) & $(0.1)$ & $(0.1)$ & $\begin{array}{l}(0.1) \\
\end{array}$ & $(0.8)$ & $(0.8)$ & $(0.7)$ & $(0.7)$ & 0.1 & $(0.2)$ & 0.1 & $(0.2)$ & $(0.7)$ & $(0.7)$ & (0.5) & $(0.5)$ \\
\hline 5 & $(0.1)$ & $(0.1)$ & $(0.1)$ & $(0.1)$ & $(0.9)$ & $(0.9)$ & $(0.7)$ & $(0.7)$ & 0.7 & 0.4 & 0.6 & 0.4 & $(0.6)$ & $(0.6)$ & (0.3) & $(0.3)$ \\
\hline 6 & $(0.2)$ & $(0.2)$ & $(0.1)$ & $\begin{array}{l}(0.1) \\
\end{array}$ & (1.0) & $(1.0)$ & $(0.9)$ & $(0.9)$ & 0. & 0. & 0.1 & 0.1 & $(0.7)$ & $(1.0)$ & (0.6) & $(0.7)$ \\
\hline 7 & $(0.1)$ & $(0.1)$ & $(0.1)$ & $(0.1)$ & $(0.4)$ & $(0.4)$ & $(0.3)$ & $(0.3)$ & 0.6 & 0.6 & 0.6 & 0.5 & $(0.5)$ & $(0.5)$ & $(0.4)$ & $(0.4)$ \\
\hline 8 & $(0.2)$ & $(0.2)$ & $(0.1)$ & $(0.1)$ & $(0.7)$ & $(0.7)$ & $(0.5)$ & $(0.5)$ & 0.2 & 0.2 & 0.3 & 0.3 & $(0.9)$ & $(1.0)$ & $(0.7)$ & $(0.8)$ \\
\hline 9 & (0.1) & $(0.1)$ & $(0.1)$ & $(0.1)$ & (0.6) & (0.6) & (0.5) & (0.5) & 0.7 & 0.3 & 0.7 & 0.3 & (0.6) & $(0.8)$ & $(0.4)$ & (0.6) \\
\hline 10 & $(0.2)$ & $(0.2)$ & $(0.1)$ & $\begin{array}{l}(0.1) \\
\end{array}$ & $(0.7)$ & (0.6) & (0.5) & $(0.5)$ & 0 & 0.3 & 0.8 & 3 & (0.7) & $(1.2)$ & $(0.7)$ & $(1.0)$ \\
\hline 11 & $(0.2)$ & $(0.2)$ & $(0$. & $(0.2)$ & $(0.8)$ & $(0.8)$ & $(0.7)$ & $(0.7)$ & 0. & 0.0 & 0.1 & 1 & $(0.5)$ & $(1.3)$ & $(0.4)$ & (1.1) \\
\hline 12 & $(0.2)$ & $(0.1)$ & $(0$. & $(0.1)$ & $(0.9)$ & $(0.9)$ & $(0.8)$ & $(0.8)$ & $(0.1$ & 0.0 & $(0.1)$ & $(0.0)$ & $(0.7)$ & $(0.9)$ & $(0.5)$ & $(0.6)$ \\
\hline 13 & $(0.2)$ & $(0.2)$ & $(0.1)$ & $\begin{array}{l}(0.1) \\
\end{array}$ & $(0.6)$ & $(0.7)$ & (0.6) & (0.6) & $(0.5)$ & $(0.4)$ & $\begin{array}{l}(0.3) \\
\end{array}$ & $(0.4)$ & $(0.8)$ & $(1.1)$ & $(0.7)$ & $(0.9)$ \\
\hline 14 & $(0.3)$ & $(0.2)$ & $(0.2)$ & $(0.2)$ & $(0.9)$ & $(0.9)$ & (0.9) & $(0.9)$ & $(0.1)$ & $(0.1)$ & (0.1) & $(0.1)$ & $(0.6)$ & $(1.2)$ & (0.6) & $(1.3)$ \\
\hline 15 & $(0.2)$ & $(0.2)$ & $(0.1)$ & $\begin{array}{l}(0.1) \\
\end{array}$ & $(0.6)$ & $(0.6)$ & $(0.2)$ & $(0.2)$ & 0.2 & 0.1 & 0.3 & 0.1 & $(0.7)$ & $(1.2)$ & $(0.4)$ & $(0.9)$ \\
\hline 16 & $(0.3)$ & $(0.3)$ & $(0.2)$ & $(0.2)$ & $(0.9)$ & $(0.9)$ & $(0.8)$ & $(0.8)$ & $(0.0)$ & $(0.2)$ & 0.1 & $(0.0)$ & $(0.9)$ & (1.8) & $(0.8)$ & (1.6) \\
\hline Houston & $(0.0)$ & $(0.0)$ & 0.1 & 0.1 & (0.5) & $(0.5)$ & $(0.4)$ & $(0.4)$ & 0.2 & 0.2 & 0.3 & 0.3 & $(0.7)$ & $(0.9)$ & $(0.6)$ & $(0.7)$ \\
\hline Phoenix & $(0.2)$ & $(0.2)$ & $(0.1)$ & $(0.1)$ & $(0.4)$ & $(0.5)$ & $(0.2)$ & $(0.2)$ & 0.1 & $(0.1)$ & 0.0 & $(0.1)$ & $(0.1)$ & $(0.8)$ & 0.3 & $(0.4)$ \\
\hline Atlanta & $(0.0)$ & $(0.0)$ & 0. & 0.0 & (0.3) & $(0.5)$ & $(0.3)$ & $(0.4)$ & 0.2 & 0.2 & 0.2 & 0.2 & $(0.5)$ & (0.6) & $(0.2)$ & $(0.4)$ \\
\hline Minneap & $(0.1)$ & $(0.1)$ & $(0.1)$ & $(0.1)$ & $(0.3)$ & $(0.4)$ & $(0.2)$ & $(0.4)$ & 0.1 & $(0.0)$ & 0.1 & 0.0 & $(0.4)$ & $(0.9)$ & $(0.0)$ & $(0.4)$ \\
\hline Chicago & $(0.1)$ & $(0.0)$ & $(0.0)$ & $(0.0)$ & $(0.4)$ & $(0.6)$ & $(0.4)$ & $(0.4)$ & $(0.4)$ & $(0.5)$ & $(0.1)$ & $(0.1)$ & (1.2) & $(1.8)$ & $(0.9)$ & (1.3) \\
\hline Wash DC & $(0.1)$ & $(0.1)$ & $(0.1)$ & $(0.1)$ & $(0.2)$ & $(0.2)$ & $(0.2)$ & $(0.2)$ & 0.8 & \begin{tabular}{l|l}
0.0 \\
\end{tabular} & 0.6 & $\begin{array}{ll}0.1 \\
\end{array}$ & $(0.5)$ & $(0.5)$ & $(0.2)$ & $\begin{array}{l}(0.3) \\
\end{array}$ \\
\hline
\end{tabular}

Table 34.

Percentage Peak Demand Savings. Baseline with attached exterior shading.

Comparison to best commercially available window (F). Baseline daylight and shading condition defined in table.

EC defined with daylight control as defined in Table. EC has no shading.

Window-to-wall ratio $=0.6$

\begin{tabular}{|c|c|c|c|c|c|c|c|c|c|c|c|c|c|c|c|c|}
\hline \multirow{2}{*}{$\begin{array}{c}\text { Zone } \\
\text { B Daylight? }\end{array}$} & \multicolumn{4}{|l|}{ North } & \multicolumn{4}{|l|}{ East } & \multicolumn{4}{|l|}{ South } & \multicolumn{4}{|l|}{ West } \\
\hline & $\mathrm{N}$ & $\mathrm{N}$ & $\mathrm{Y}$ & $\mathrm{Y}$ & $\mathrm{N}$ & $\mathrm{N}$ & $\mathrm{Y}$ & $\mathrm{Y}$ & $\mathrm{N}$ & $\mathrm{N}$ & $\mathrm{Y}$ & $\mathrm{Y}$ & $\mathrm{N}$ & $\mathrm{N}$ & $\mathrm{Y}$ & $\mathrm{Y}$ \\
\hline B Shade? & $\mathrm{N}$ & $\mathrm{Y}$ & $\mathrm{N}$ & $\mathrm{Y}$ & $\mathrm{N}$ & $\mathrm{Y}$ & $\mathrm{N}$ & $\bar{Y}$ & $\mathrm{~N}$ & $\overline{\mathrm{Y}}$ & $\mathrm{N}$ & $\mathrm{Y}$ & $\mathrm{N}$ & $\overline{\mathrm{Y}}$ & $\mathrm{N}$ & $\bar{Y}$ \\
\hline E Daylight? & $\mathrm{N}$ & $\mathrm{N}$ & $\mathrm{Y}$ & $\bar{Y}$ & $\mathrm{~N}$ & $\mathrm{~N}$ & $\mathrm{Y}$ & $\mathrm{Y}$ & $\mathrm{N}$ & $\mathrm{N}$ & $\mathrm{Y}$ & $\bar{Y}$ & $\mathrm{~N}$ & $\mathrm{~N}$ & $\mathrm{Y}$ & $\mathrm{Y}$ \\
\hline E Shade? & $\mathrm{N}$ & $\mathrm{N}$ & $\mathrm{N}$ & $\mathrm{N}$ & $\mathrm{N}$ & $\mathrm{N}$ & $\mathrm{N}$ & $\mathrm{N}$ & $\bar{N}$ & $\mathrm{~N}$ & $\mathrm{~N}$ & $\mathrm{~N}$ & $\mathrm{~N}$ & $\mathrm{~N}$ & $\mathrm{~N}$ & $\mathrm{~N}$ \\
\hline \multicolumn{17}{|l|}{ Climate } \\
\hline 1 & (3.3) & (3.0) & (3.4) & (3.1) & (18.3) & (18.2) & (16.9) & (16.8) & 9.4 & 3.2 & 9.5 & 3.5 & (27.9) & (45.3) & (17.7) & (39.1) \\
\hline 2 & (2.9) & (3.5) & (2.6) & (3.1) & (15.1) & (15.1) & (17.5) & (17.5) & 15.5 & 6.2 & 17.9 & 7.3 & (16.1) & (20.9) & (14.8) & (18.9) \\
\hline 3 & (3.6) & (3.5) & (3.1) & (2.9) & (11.3) & (11.3) & (9.5) & (9.6) & 96 & 9.1 & 9.1 & 8.9 & (21.2) & (21.3) & (15.5) & $(15.7)$ \\
\hline 4 & $(1.7$ & (1.8) & $(1.8)$ & (1.8) & (16.2) & (16.3) & (16.6) & (16.6) & .9 & (4.2) & 2.0 & (4.5) & (14.7) & (14.9) & (12.6) & (12.8) \\
\hline 5 & $(3.6)$ & $\begin{array}{l}(2.8) \\
\end{array}$ & (2.3) & $\begin{array}{l}(2.5) \\
\end{array}$ & (18.7) & (18.8) & (17.7) & (17.7) & 11 & 7.5 & 12.1 & 7.8 & (14.3) & (14.5) & (7.1) & $(9.2)$ \\
\hline 6 & $(4.9$ & (4.9) & (4.2) & (4.1) & (22.5) & (22.4) & (22.6) & (22.6) & & 1. & 1.2 & 0 & (15.7) & (21.2) & (15.4) & $(20.0)$ \\
\hline 7 & $3.1)$ & (3.1) & (3.0) & $(2.5$ & $(9.2)$ & $(9.2)$ & (7.8) & (7.8) & & 9.7 & 11.4 & 11.2 & (10.5) & (11.9) & (9.5) & (10.9) \\
\hline 8 & (5.2) & (5.2) & $(4.4)$ & (4.4) & (13.6) & (13.6) & (12.8) & (12.9) & & 3.9 & 4.9 & 4.9 & (19.2) & (21.3) & (17.6) & (20.5) \\
\hline 9 & (2.6) & (2.6) & (2.0) & (2.0) & (11.8) & (11.8) & $(12.0)$ & (12.0) & 10.0 & 3.8 & 11.8 & 4.7 & (11.5) & (17.2) & (8.3) & (15.5) \\
\hline 10 & (3.8) & (3.8) & (2.5) & (2.6) & (12.1) & (12.0) & (12.3) & (12.2) & 10.5 & 4.6 & 12.2 & 5.3 & $(13.2)$ & (24.8) & $(17.2)$ & (25.0) \\
\hline 11 & & (4.6) & (3.8) & (3.9) & $\begin{array}{l}(14.4) \\
\end{array}$ & (14.6) & (14.5) & (15.1) & & 0.4 & 1.9 & 5 & $(7.7)$ & (24.8) & (8.7) & (23.6) \\
\hline 12 & 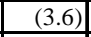 & (2.7) & (3.4) & (2.5) & (17.3) & (17.4) & $\begin{array}{l}(18.7) \\
\end{array}$ & (18.7) & ) & 0.4 & (1.4) & $(0.4)$ & (14.7) & (17.5) & (10.7) & $(14.6)$ \\
\hline 13 & 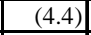 & (4.4) & (3.) & (3.8) & (11.3) & (11.4) & (13.1) & (13.2) & 88 & (8.1) & (6.6) & (8.0) & (14.7) & (19.5) & (15.1) & $(20.0)$ \\
\hline 1 & (5.5) & (5.4) & $(4$. & (4.6) & (15.3) & (15.4) & (18.6) & (18.7) & (1.4) & (1.7) & (1.6) & (2.0) & (8.8) & (21.6) & $(10.8)$ & (26.6) \\
\hline 15 & $(4.0)$ & $(4.2)$ & (2.9) & (2.9) & (9.4) & (9.5) & (4.3) & (4.4) & & 1.0 & 3.9 & 1.3 & (11.3) & (21.2) & (7.8) & (16.1) \\
\hline 16 & (6.6) & (6.9) & (4.9) & (5.1) & $(15.2)$ & (15.4) & $(17.0)$ & (17.2) & $(0.7)$ & (2.5) & 1.5 & $(0.3)$ & (15.5) & (38.2) & (16.4) & (38.5) \\
\hline Houston & $(0.0)$ & $(0.2)$ & 3.2 & 3.1 & (8.5) & (8.5) & (8.3) & (8.3) & 3.8 & 3.5 & 5.3 & 5.0 & (12.5) & (17.4) & $(12.0)$ & (16.0) \\
\hline Phoenix & (3.4) & (3.4) & (1.3) & (1.3) & (5.9) & (8.9) & (3.2) & (4.3) & .1 & $(0.8)$ & 0.2 & (1.2) & $(0.9)$ & (12.5) & 4.2 & $(7.4)$ \\
\hline Atlanta & (0.5) & $\begin{array}{l}(0.6) \\
\end{array}$ & 1. & 1. & (5.4) & (10.5) & (5.9) & $\begin{array}{l}(9.7) \\
\end{array}$ & 2. & 2.7 & 3.3 & 3.3 & (9.6) & (13.2) & (4.3) & $\begin{array}{l}(10.9) \\
\end{array}$ \\
\hline Minneap & $(1.6$ & (1.7) & (1.5) & $(1.6$ & (4.9) & (8.3) & (5.2) & (8.5) & \pm & $(0.5)$ & 1.8 & 0.3 & (9.6) & (22.1) & $(0.4)$ & (9.9) \\
\hline Chicago & $(1.3$ & $(1.2)$ & $(0.5)$ & $(0.5)$ & (8.4) & (10.9) & (8.4) & (10.6) & $(9.0)$ & $(10.4)$ & (1.4) & (1.5) & (25.0) & (43.2) & $(22.2)$ & (37.2) \\
\hline Wash DC & (1.8) & (1.9) & $(1.5)$ & (1.6) & (4.4) & (4.4) & (4.7) & (4.7) & 13.4 & $\begin{array}{ll}0.3 \\
\end{array}$ & 11.9 & 3.0 & (9.1) & $(10.0)$ & $(4.4)$ & $(7.6$ \\
\hline
\end{tabular}


Table 35.

Primary Annual Energy Use Savings (kBtu/ ft2-floor-yr). Baseline and EC with horizon exterior obstruction.

Comparison to best commercially available window $(\mathrm{F})$. Baseline daylight and shading condition defined in table.

EC defined with daylight control as defined in Table. EC has no interior shades.

Window-to-wall ratio $=0.3$

\begin{tabular}{|c|c|c|c|c|c|c|c|c|c|c|c|c|c|c|c|c|}
\hline \multirow{2}{*}{$\begin{array}{c}\text { Zone } \\
\text { B Daylight? }\end{array}$} & \multicolumn{4}{|l|}{ North } & \multicolumn{4}{|l|}{ East } & \multicolumn{4}{|l|}{ South } & \multicolumn{4}{|l|}{ West } \\
\hline & $\mathrm{N}$ & $\mathrm{N}$ & $\mathrm{Y}$ & $\mathrm{Y}$ & $\mathrm{N}$ & $\mathrm{N}$ & $\mathrm{Y}$ & $\mathrm{Y}$ & $\mathrm{N}$ & $\mathrm{N}$ & $\mathrm{Y}$ & $\mathrm{Y}$ & $\mathrm{N}$ & $\mathrm{N}$ & $\mathrm{Y}$ & $\mathrm{Y}$ \\
\hline B Shade? & $\mathrm{N}$ & $\mathrm{Y}$ & $\mathrm{N}$ & $\mathrm{Y}$ & $\mathrm{N}$ & $\mathrm{Y}$ & $\mathrm{N}$ & $\mathrm{Y}$ & $\mathrm{N}$ & $\mathrm{Y}$ & $\mathrm{N}$ & $\mathrm{Y}$ & $\mathrm{N}$ & $\mathrm{Y}$ & $\mathrm{N}$ & $\mathrm{Y}$ \\
\hline E Daylight? & $\mathrm{N}$ & $\mathrm{N}$ & $\mathrm{Y}$ & $\mathrm{Y}$ & $\mathrm{N}$ & $\mathrm{N}$ & $\mathrm{Y}$ & $\mathrm{Y}$ & $\mathrm{N}$ & $\mathrm{N}$ & $\mathrm{Y}$ & $\mathrm{Y}$ & $\mathrm{N}$ & $\mathrm{N}$ & $\mathrm{Y}$ & $\mathrm{Y}$ \\
\hline \multicolumn{17}{|l|}{ Climate } \\
\hline 1 & $(0.8)$ & $\begin{array}{l}(0.8) \\
\end{array}$ & 0.2 & 0.2 & 0.9 & 0.9 & 2.2 & 2.2 & 6.8 & 3.5 & 7.9 & 4.4 & 1.2 & 0.9 & 2.5 & 2.1 \\
\hline 4 & (1.3) & (1.2) & $(0.6)$ & $(0.5)$ & 1.0 & 0.1 & 2.2 & 1.1 & 1.2 & $(1.7)$ & 2.0 & (1.1) & 1.3 & 0.1 & 2.4 & 1.2 \\
\hline 5 & (1.1) & $(0.8)$ & $(0.4)$ & $(0.0)$ & 1.4 & 0.6 & 2.5 & 1.5 & 1.9 & $(1.6)$ & 2.6 & $(1.0)$ & 1.6 & $(0.0)$ & 2.7 & 0.9 \\
\hline 6 & (1.6) & (1.4) & (0.9) & $(0.7)$ & $(0.1)$ & $(0.5)$ & 1.1 & 0.6 & 1.1 & (1.8) & 2.0 & $(1.0)$ & 0.7 & (1.1) & 1.8 & $(0.1)$ \\
\hline 7 & (1.4) & (1.2) & $(0.6)$ & $(0.4)$ & $(0.2)$ & $(0.8)$ & 0.9 & 0.3 & 1.0 & (1.8) & 1.8 & $(1.0)$ & 0.5 & $(1.2)$ & 1.6 & $(0.2)$ \\
\hline 8 & \begin{tabular}{l|l}
$(1.2)$ \\
\end{tabular} & (1.1) & (0.6) & $(0.5)$ & 0.2 & $(0.3)$ & 1.1 & 0.6 & 1.6 & $(2.0)$ & 2.2 & (1.5) & 0.2 & (0.5) & 1.0 & 0.3 \\
\hline 13 & (1.8) & (1.4) & (1.2) & \begin{tabular}{l|l}
$(0.9)$ \\
\end{tabular} & 2.0 & $(0.2)$ & 3.0 & 0.6 & 1.8 & (1.1) & 2.5 & $(0.5)$ & 1.5 & $(2.0)$ & 2.3 & (1.4) \\
\hline 14 & (2.3) & $(2.1)$ & (1.9) & (1.6) & 1.6 & $(1.7)$ & 2.6 & $(0.7)$ & 0.9 & (2.9) & 1.4 & $(2.3)$ & 1.2 & $(2.6)$ & 2.3 & (1.9) \\
\hline 15 & (2.5) & (2.3) & (2.0) & (1.7) & 1.2 & $(0.2)$ & 1.9 & 0.6 & 1.1 & (1.9) & 1.8 & $(1.2)$ & $(0.4)$ & $(1.2)$ & 0.3 & $(0.5)$ \\
\hline 16 & (1.8) & $(1.7)$ & $(1.2)$ & (1.1) & 2.7 & $(0.1)$ & 3.7 & 0.8 & 5.9 & 2.2 & 6.2 & 2.6 & 1.9 & (1.9) & 3.2 & (1.1) \\
\hline Houston & (1.5) & (1.4) & $(0.5)$ & $(0.4)$ & $(0.7)$ & (1.4) & 0.2 & (0.4) & 0.2 & (1.5) & 1.3 & (0.5) & $(0.8)$ & (1.7) & 0.0 & $(0.8)$ \\
\hline Phoenix & (2.2) & $(2.0)$ & (1.6) & (1.3) & 0.8 & (1.5) & 1.8 & $(0.4)$ & 0.8 & (2.5) & 1.4 & (1.8) & $(0.1)$ & (1.9) & 0.7 & (1.3) \\
\hline Atlanta & (1.5) & (1.3) & $(0.7)$ & $(0.5)$ & 1.1 & 0.3 & 2.1 & 1.3 & 1.9 & $(2.6)$ & 2.7 & (1.7) & 0.8 & (1.3) & 1.7 & $(0.6)$ \\
\hline Minneap & $(2.2)$ & $(2.1)$ & (1.3) & $(1.2)$ & 2.2 & $(2.3)$ & 3.2 & (1.6) & 1.2 & $(0.6)$ & 1.7 & 0.1 & 0.1 & (1.3) & 1.1 & (1.0) \\
\hline Chicago & $(2.0)$ & $(2.0)$ & $(1.2)$ & (1.2) & 1.8 & 0.1 & 2.7 & 1.0 & 3.8 & 2.6 & 4.3 & 3.2 & 1.1 & 0.9 & 2.0 & 1.8 \\
\hline Wash DC & (2.1) & (1.9) & (1.3) & (1.1) & 0.9 & (1.1) & 1.8 & $(0.3)$ & 8.1 & 3.4 & 8.9 & 4.1 & 1.3 & $(1.2)$ & 2.5 & 0.2 \\
\hline
\end{tabular}

Table 36.

Percentage Primary Annual Energy Use Savings. Baseline and EC with horizon exterior obstruction.

Comparison to best commercially available window (F). Baseline daylight and shading condition defined in table.

EC defined with daylight control as defined in Table. EC has no interior shades.

Window-to-wall ratio $=0.3$

\begin{tabular}{|c|c|c|c|c|c|c|c|c|c|c|c|c|c|c|c|c|}
\hline \multirow{2}{*}{\begin{tabular}{|c|} 
Zone \\
B Daylight?
\end{tabular}} & \multicolumn{4}{|l|}{ North } & \multicolumn{4}{|l|}{ East } & \multicolumn{4}{|l|}{ South } & \multicolumn{4}{|l|}{ West } \\
\hline & $\mathrm{N}$ & $\mathrm{N}$ & $\mathrm{Y}$ & $\mathrm{Y}$ & $\mathrm{N}$ & $\mathrm{N}$ & $\mathrm{Y}$ & $\bar{Y}$ & $\mathrm{~N}$ & $\mathrm{~N}$ & $\mathrm{Y}$ & $\mathrm{Y}$ & $\mathrm{N}$ & $\mathrm{N}$ & $\mathrm{Y}$ & $\bar{Y}$ \\
\hline B Shade? & $\mathrm{N}$ & $\mathrm{Y}$ & $\mathrm{N}$ & $\mathrm{Y}$ & $\mathrm{N}$ & $\mathrm{Y}$ & $\mathrm{N}$ & $\mathrm{Y}$ & $\mathrm{N}$ & $\mathrm{Y}$ & $\mathrm{N}$ & $\mathrm{Y}$ & $\mathrm{N}$ & $\mathrm{Y}$ & $\mathrm{N}$ & $\mathrm{Y}$ \\
\hline E Daylight? & $\mathrm{N}$ & $\mathrm{N}$ & $\mathrm{Y}$ & $\mathrm{Y}$ & $\mathrm{N}$ & $\mathrm{N}$ & $\mathrm{Y}$ & $\mathrm{Y}$ & $\mathrm{N}$ & $\mathrm{N}$ & $\mathrm{Y}$ & $\mathrm{Y}$ & $\mathrm{N}$ & $\mathrm{N}$ & $\mathrm{Y}$ & $\mathrm{Y}$ \\
\hline \multicolumn{17}{|l|}{ Climate } \\
\hline 1 & $(0.7)$ & $(0.7)$ & 0.2 & 0.3 & 0.8 & 0.8 & 2.2 & 2.2 & 5.2 & 2.8 & 7.2 & 4.2 & 1.0 & 0.7 & 2.3 & 2.0 \\
\hline 4 & (1.1) & $(1.0)$ & $(0.7)$ & $(0.5)$ & 0.8 & 0.0 & 2.0 & 1.0 & 0.9 & $(1.2)$ & 1.7 & $(0.9)$ & 0.9 & 0.1 & 2.1 & 1.1 \\
\hline 5 & (0.9) & (0.6) & $(0.4)$ & $(0.0)$ & 1.0 & 0.5 & 2.3 & 1.4 & 1.3 & $(1.2)$ & 2.2 & $(0.9)$ & 1.2 & $(0.0)$ & 2.5 & 0.9 \\
\hline 6 & (1.3) & (1.1) & (0.9) & $(0.7)$ & $(0.1)$ & $(0.4)$ & 0.9 & 0.5 & 0.8 & $(1.2)$ & 1.6 & $(0.9)$ & 0.5 & $(0.8)$ & 1.5 & $(0.1)$ \\
\hline 7 & (1.1) & (1.0) & $(0.6)$ & $(0.4)$ & $(0.2)$ & $(0.6)$ & 0.8 & 0.3 & 0.7 & (1.3) & 1.5 & $(0.9)$ & 0.4 & $(0.9)$ & 1.4 & $(0.2)$ \\
\hline 8 & (1.0) & (0.9) & (0.6) & $(0.5)$ & 0.2 & $(0.2)$ & 1.0 & 0.5 & 1.0 & (1.3) & 1.8 & $(1.2)$ & 0.2 & $(0.4)$ & 0.8 & 0.2 \\
\hline 13 & (1.4) & (1.1) & (1.1) & $(0.8)$ & 1.4 & $(0.1)$ & 2.4 & 0.5 & 1.2 & $(0.7)$ & 1.9 & $(0.4)$ & 1.0 & (1.4) & 1.9 & $(1.2)$ \\
\hline 14 & (1.7) & (1.5) & \begin{tabular}{l|}
$(1.7)$ \\
\end{tabular} & (1.5) & 1.0 & (1.1) & 2.0 & $(0.6)$ & 0.5 & (1.8) & 1.0 & (1.7) & 0.8 & (1.7) & 1.8 & (1.5) \\
\hline 15 & (1.7) & \begin{tabular}{l|}
$(1.6)$ \\
\end{tabular} & \begin{tabular}{l|}
$(1.7)$ \\
\end{tabular} & (1.5) & 0.7 & $(0.1)$ & 1.4 & 0.4 & 0.6 & $(1.1)$ & 1.2 & $(0.9)$ & $(0.2)$ & $(0.7)$ & 0.2 & $(0.4)$ \\
\hline 16 & (1.5) & $(1.4)$ & $(1.2)$ & (1.1) & 2.0 & $(0.1)$ & 3.1 & 0.7 & 4.1 & 1.6 & 5.2 & 2.2 & 1.4 & $(1.4)$ & 2.7 & $(1.0)$ \\
\hline Houston & (1.1) & $(1.0)$ & $(0.5)$ & $(0.4)$ & (0.5) & $(1.0)$ & 0.2 & (0.3) & 0.1 & $(1.0)$ & 1.0 & $(0.4)$ & $(0.6)$ & (1.1) & 0.0 & $(0.7)$ \\
\hline Phoenix & (1.5) & (1.4) & (1.3) & (1.1) & 0.5 & (1.0) & 1.3 & $(0.3)$ & 0.4 & (1.5) & 1.0 & (1.3) & $(0.1)$ & (1.2) & 0.5 & $(0.9)$ \\
\hline Atlanta & (1.1) & $(1.0)$ & $(0.6)$ & $(0.5)$ & 0.8 & 0.2 & 1.8 & 1.1 & 1.3 & (1.8) & 2.1 & (1.4) & 0.5 & (0.9) & 1.4 & $(0.5)$ \\
\hline Minneap & (1.7) & $(1.7)$ & $(1.2)$ & (1.1) & 1.5 & (1.6) & 2.5 & (1.3) & 0.8 & $(0.4)$ & 1.4 & 0.1 & 0.1 & $(0.9)$ & 0.9 & $(0.8)$ \\
\hline Chicago & (1.6) & (1.6) & (1.1) & (1.1) & 1.3 & 0.1 & 2.3 & 0.8 & 2.7 & 1.9 & 3.6 & 2.7 & 0.8 & 0.6 & 1.6 & 1.5 \\
\hline Wash DC & (1.6) & (1.5) & $(1.2)$ & (1.1) & 0.7 & (0.8) & 1.5 & (0.3) & 5.5 & 2.4 & 7.1 & 3.4 & 0.9 & $(0.9)$ & 2.1 & 0.2 \\
\hline
\end{tabular}


Table 37.

Primary Annual Energy Use Savings (kBtu/ ft2-floor-yr). Baseline and EC with horizon exterior obstruction.

Comparison to best commercially available window $(\mathrm{F})$. Baseline daylight and shading condition defined in table.

EC defined with daylight control as defined in Table. EC has no interior shades.

Window-to-wall ratio $=0.6$

\begin{tabular}{|c|c|c|c|c|c|c|c|c|c|c|c|c|c|c|c|c|}
\hline \multirow{2}{*}{$\begin{array}{c}\text { Zone } \\
\text { B Daylight? }\end{array}$} & \multicolumn{4}{|l|}{ North } & \multicolumn{4}{|l|}{ East } & \multicolumn{4}{|l|}{ South } & \multicolumn{4}{|l|}{ West } \\
\hline & $\mathrm{N}$ & $\mathrm{N}$ & $\mathrm{Y}$ & $\mathrm{Y}$ & $\mathrm{N}$ & $\mathrm{N}$ & $\mathrm{Y}$ & $\mathrm{Y}$ & $\mathrm{N}$ & $\mathrm{N}$ & $\mathrm{Y}$ & $\mathrm{Y}$ & $\mathrm{N}$ & $\mathrm{N}$ & $\mathrm{Y}$ & $\mathrm{Y}$ \\
\hline B Shade? & $\mathrm{N}$ & $\mathrm{Y}$ & $\mathrm{N}$ & $\mathrm{Y}$ & $\mathrm{N}$ & $\mathrm{Y}$ & $\mathrm{N}$ & $\mathrm{Y}$ & $\mathrm{N}$ & $\mathrm{Y}$ & $\mathrm{N}$ & $\mathrm{Y}$ & $\mathrm{N}$ & $\mathrm{Y}$ & $\mathrm{N}$ & $\mathrm{Y}$ \\
\hline E Daylight? & $\mathrm{N}$ & $\mathrm{N}$ & $\mathrm{Y}$ & $\mathrm{Y}$ & $\mathrm{N}$ & $\mathrm{N}$ & $\mathrm{Y}$ & $\mathrm{Y}$ & $\mathrm{N}$ & $\mathrm{N}$ & $\mathrm{Y}$ & $\mathrm{Y}$ & $\mathrm{N}$ & $\mathrm{N}$ & $\mathrm{Y}$ & $\mathrm{Y}$ \\
\hline \multicolumn{17}{|l|}{ Climate } \\
\hline 1 & 1.5 & 1.6 & 1.8 & 1.9 & 11.0 & 0.7 & 12.1 & 1.3 & 26.5 & 13.9 & 27.7 & 13.3 & 13.1 & 0.6 & 15.1 & 0.4 \\
\hline 4 & 1.6 & 1.7 & 1.4 & 1.5 & 13.4 & 4.2 & 14.3 & 5.5 & 18.0 & 7.5 & 18.7 & 7.4 & 15.2 & 6.6 & 16.1 & 7.0 \\
\hline 5 & 1.3 & 1.6 & 1.2 & 1.5 & 13.3 & (3.4) & 14.0 & (3.6) & 21.3 & 8.7 & 22.1 & 8.5 & 15.8 & 5.2 & 16.7 & 4.8 \\
\hline 6 & 1.4 & 1.7 & 1.5 & 1.8 & 10.2 & 2.0 & 10.9 & 2.8 & 18.9 & 7.8 & 20.0 & 7.5 & 13.4 & 5.1 & 14.2 & 5.4 \\
\hline 7 & 2.8 & 1.5 & 2.7 & 1.6 & 11.2 & 3.9 & 12.0 & 5.3 & 18.8 & 9.5 & 19.6 & 9.9 & 14.3 & 5.6 & 15.0 & 6.0 \\
\hline 8 & 2.3 & 2.5 & 2.3 & 2.6 & 11.0 & 3.1 & 11.6 & 4.1 & 19.9 & 7.6 & 20.7 & 7.4 & 11.8 & 4.1 & 12.1 & 4.0 \\
\hline 13 & 1.0 & 1.9 & 0.9 & 1.9 & 16.5 & 4.2 & 17.1 & 4.8 & 19.7 & 8.5 & 20.3 & 8.5 & 17.0 & 3.2 & 17.9 & 3.0 \\
\hline 14 & 0.3 & 0.5 & $(0.1)$ & 0.2 & 15.3 & 3.5 & 15.9 & 4.5 & 18.1 & 6.6 & 18.5 & 6.7 & 16.2 & 1.6 & 16.9 & 1.0 \\
\hline 15 & 0.3 & 0.6 & 0.2 & 0.5 & 12.1 & 1.6 & 12.5 & 2.2 & 17.7 & 7.9 & 18.3 & 8.0 & 11.9 & 3.4 & 12.4 & 3.3 \\
\hline 16 & $(0.3)$ & $(0.1)$ & $(0.4)$ & $(0.2)$ & 17.0 & 7.9 & 17.5 & 8.8 & 25.2 & 11.9 & 25.2 & 11.4 & 16.6 & 0.1 & 17.9 & $(0.2)$ \\
\hline Houston & 0.9 & 1.2 & 1.2 & 1.6 & 7.0 & $(0.0)$ & 7.5 & 0.5 & 13.2 & 7.2 & 14.2 & 8.2 & 8.8 & 0.2 & 9.6 & 0.3 \\
\hline Phoenix & 0.6 & 1.0 & $(0.2)$ & 0.2 & 12.7 & 2.0 & 13.4 & 2.9 & 16.8 & 7.2 & 17.2 & 7.3 & 12.9 & 2.2 & 13.8 & 2.0 \\
\hline Atlanta & 1.0 & 1.2 & 1.2 & 1.4 & 12.3 & 5.5 & 12.9 & 6.5 & 17.8 & 4.3 & 18.6 & 4.3 & 11.6 & 2.5 & 12.8 & 2.7 \\
\hline Minneap & (1.4) & $(1.2)$ & (1.8) & (1.6) & 19.3 & 3.8 & 20.0 & 4.3 & 16.5 & 11.9 & 16.7 & 12.1 & 15.4 & 1.6 & 16.5 & 2.1 \\
\hline Chicago & $(0.5)$ & $(0.4)$ & $(0.4)$ & $(0.2)$ & 12.9 & 5.2 & 13.4 & 5.9 & 19.0 & 12.1 & 19.2 & 12.1 & 11.7 & $(2.1)$ & 12.3 & $(2.1)$ \\
\hline Wash DC & $(0.7)$ & $(0.4)$ & $(0.6)$ & $(0.2)$ & 10.6 & 0.2 & 11.1 & 0.6 & 26.0 & 13.0 & 26.8 & 13.2 & 13.5 & 0.8 & 14.8 & 1.0 \\
\hline
\end{tabular}

Table 38.

Percentage Primary Annual Energy Use Savings. Baseline and EC with horizon exterior obstruction.

Comparison to best commercially available window (F). Baseline daylight and shading condition defined in table.

EC defined with daylight control as defined in Table. EC has no interior shades.

Window-to-wall ratio $=0.6$

\begin{tabular}{|c|c|c|c|c|c|c|c|c|c|c|c|c|c|c|c|c|}
\hline \multirow{2}{*}{\begin{tabular}{|c|} 
Zone \\
B Daylight?
\end{tabular}} & \multicolumn{4}{|l|}{ North } & \multicolumn{4}{|l|}{ East } & \multicolumn{4}{|l|}{ South } & \multicolumn{4}{|l|}{ West } \\
\hline & $\mathrm{N}$ & $\mathrm{N}$ & $\mathrm{Y}$ & $\mathrm{Y}$ & $\mathrm{N}$ & $\mathrm{N}$ & $\mathrm{Y}$ & $\mathrm{Y}$ & $\mathrm{N}$ & $\mathrm{N}$ & $\bar{Y}$ & $\mathrm{Y}$ & $\mathrm{N}$ & $\mathrm{N}$ & $\mathrm{Y}$ & $\bar{Y}$ \\
\hline B Shade? & $\mathrm{N}$ & $\mathrm{Y}$ & $\mathrm{N}$ & $\mathrm{Y}$ & $\mathrm{N}$ & $\mathrm{Y}$ & $\mathrm{N}$ & $\mathrm{Y}$ & $\mathrm{N}$ & $\mathrm{Y}$ & $\mathrm{N}$ & $\mathrm{Y}$ & $\mathrm{N}$ & $\mathrm{Y}$ & $\mathrm{N}$ & $\mathrm{Y}$ \\
\hline E Daylight? & $\mathrm{N}$ & $\mathrm{N}$ & $\mathrm{Y}$ & $\mathrm{Y}$ & $\mathrm{N}$ & $\mathrm{N}$ & $\mathrm{Y}$ & $\mathrm{Y}$ & $\mathrm{N}$ & $\mathrm{N}$ & $\mathrm{Y}$ & $\mathrm{Y}$ & $\mathrm{N}$ & $\mathrm{N}$ & $\mathrm{Y}$ & $\mathrm{Y}$ \\
\hline \multicolumn{17}{|l|}{ Climate } \\
\hline 1 & 1.3 & 1.4 & 2.0 & 2.1 & 7.8 & 0.6 & 10.2 & 1.2 & 16.4 & 9.3 & 19.8 & 10.6 & 8.7 & 0.4 & 11.5 & 0.3 \\
\hline 4 & 1.3 & 1.4 & 1.5 & 1.6 & 8.5 & 2.9 & 10.7 & 4.4 & 10.4 & 4.6 & 12.7 & 5.5 & 9.8 & 4.5 & 12.5 & 5.8 \\
\hline 5 & 1.1 & 1.4 & 1.2 & 1.6 & 8.6 & (2.4) & 10.7 & (3.2) & 12.4 & 5.4 & 15.0 & 6.4 & 10.4 & 3.7 & 13.0 & 4.1 \\
\hline 6 & 1.1 & 1.3 & 1.4 & 1.8 & 6.5 & 1.4 & 8.3 & 2.3 & 10.7 & 4.7 & 13.2 & 5.4 & 8.3 & 3.4 & 10.6 & 4.3 \\
\hline 7 & 2.1 & 1.2 & 2.6 & 1.6 & 7.3 & 2.7 & 9.6 & 4.5 & 11.0 & 5.9 & 13.6 & 7.4 & 9.1 & 3.8 & 11.5 & 5.0 \\
\hline 8 & 1.8 & 2.0 & 2.3 & 2.5 & 7.0 & 2.1 & 8.9 & 3.3 & 11.0 & 4.5 & 13.4 & 5.3 & 7.3 & 2.6 & 9.0 & 3.2 \\
\hline 13 & 0.7 & 1.4 & 0.8 & 1.7 & 9.3 & 2.5 & 11.2 & 3.4 & 10.4 & 4.8 & 12.4 & 5.6 & 9.4 & 1.9 & 11.4 & 2.1 \\
\hline 14 & 0.2 & 0.4 & $(0.1)$ & 0.2 & 8.2 & 2.0 & 9.9 & 3.0 & 9.2 & 3.6 & 10.9 & 4.2 & 8.7 & 0.9 & 10.5 & 0.7 \\
\hline 15 & 0.2 & 0.4 & 0.2 & 0.4 & 6.5 & 0.9 & 7.9 & 1.5 & 8.8 & 4.1 & 10.5 & 4.9 & 6.4 & 1.9 & 7.8 & 2.2 \\
\hline 16 & $(0.2)$ & $(0.1)$ & $(0.4)$ & $(0.2)$ & 9.8 & 4.8 & 11.6 & 6.2 & 13.9 & 7.1 & 16.1 & 8.0 & 9.4 & 0.0 & 11.6 & $(0.1)$ \\
\hline Houston & 0.6 & 0.9 & 1.0 & 1.3 & 4.3 & $(0.0)$ & 5.5 & 0.3 & 7.6 & 4.3 & 9.7 & 5.8 & 5.2 & 0.1 & 6.8 & 0.2 \\
\hline Phoenix & 0.4 & 0.6 & $(0.2)$ & 0.2 & 6.9 & 1.2 & 8.5 & 2.0 & 8.5 & 3.8 & 10.1 & 4.6 & 6.9 & 1.3 & 8.7 & 1.4 \\
\hline Atlanta & 0.7 & 0.9 & 1.1 & 1.3 & 7.4 & 3.5 & 9.1 & 4.8 & 10.0 & 2.6 & 12.1 & 3.1 & 6.9 & 1.6 & 8.9 & 2.0 \\
\hline Minneap & (0.9) & $(0.8)$ & (1.5) & (1.3) & 10.4 & 2.2 & 12.2 & 2.9 & 9.0 & 6.7 & 10.4 & 7.8 & 8.6 & 0.9 & 10.5 & 1.5 \\
\hline Chicago & $(0.4)$ & (0.3) & (0.3) & $(0.1)$ & 7.5 & 3.2 & 9.0 & 4.1 & 10.8 & 7.2 & 12.6 & 8.4 & 6.6 & (1.3) & 7.9 & (1.5) \\
\hline Wash DC & (0.5) & $(0.3)$ & $(0.5)$ & $(0.2)$ & 6.3 & 0.1 & 7.6 & 0.4 & 14.3 & 7.7 & 16.9 & 9.1 & 7.9 & 0.5 & 10.0 & 0.7 \\
\hline
\end{tabular}


Table 39.

Peak Demand Savings (W/ft2). Baseline and EC with horizon exterior obstruction.

Comparison to best commercially available window (F). Baseline daylight and shading condition defined in table.

EC defined with daylight control as defined in Table. EC has no interior shades.

Window-to-wall ratio $=0.3$

\begin{tabular}{|c|c|c|c|c|c|c|c|c|c|c|c|c|c|c|c|c|}
\hline Zone & North & & & & East & & & & South & & & & West & & & \\
\hline B Daylight? & $\mathrm{N}$ & $\mathrm{N}$ & $\mathrm{Y}$ & $\mathrm{Y}$ & $\mathrm{N}$ & $\mathrm{N}$ & $\mathrm{Y}$ & $\mathrm{Y}$ & $\mathrm{N}$ & $\mathrm{N}$ & $\mathrm{Y}$ & $\mathrm{Y}$ & $\mathrm{N}$ & $\mathrm{N}$ & $\mathrm{Y}$ & $\mathrm{Y}$ \\
\hline B Shade? & $\mathrm{N}$ & $\mathrm{Y}$ & $\mathrm{N}$ & $\mathrm{Y}$ & $\mathrm{N}$ & $\mathrm{Y}$ & $\mathrm{N}$ & $\mathrm{Y}$ & $\mathrm{N}$ & $\mathrm{Y}$ & $\mathrm{N}$ & $\mathrm{Y}$ & $\mathrm{N}$ & $\mathrm{Y}$ & $\mathrm{N}$ & $\mathrm{Y}$ \\
\hline E Daylight? & $\mathrm{N}$ & $\mathrm{N}$ & $\mathrm{Y}$ & $\mathrm{Y}$ & $\mathrm{N}$ & $\mathrm{N}$ & $\mathrm{Y}$ & $\mathrm{Y}$ & $\mathrm{N}$ & $\mathrm{N}$ & $\mathrm{Y}$ & $\mathrm{Y}$ & $\mathrm{N}$ & $\mathrm{N}$ & $\mathrm{Y}$ & $\mathrm{Y}$ \\
\hline E Shade? & $\mathrm{N}$ & $\mathrm{N}$ & $\mathrm{N}$ & $\mathrm{N}$ & $\mathrm{N}$ & $\mathrm{N}$ & $\mathrm{N}$ & $\mathrm{N}$ & $\mathrm{N}$ & $\mathrm{N}$ & $\mathrm{N}$ & $\mathrm{N}$ & $\mathrm{N}$ & $\mathrm{N}$ & $\mathrm{N}$ & $\mathrm{N}$ \\
\hline \multicolumn{17}{|l|}{ Climate } \\
\hline 1 & (0.0) & $(0.0)$ & $(0.0)$ & $\begin{array}{l}(0.0) \\
\end{array}$ & 0.2 & 0.2 & 0.1 & 0.1 & 0.4 & 0.3 & 0.3 & 0.2 & 0.1 & 0.1 & 0.1 & 0.1 \\
\hline 2 & $(0.1)$ & $(0.1)$ & $(0.1)$ & $(0.1)$ & 0.2 & 0.1 & 0.1 & 0.1 & 0.5 & 0.4 & 0.4 & 0.2 & 0.2 & 0.1 & 0.1 & 0.1 \\
\hline 3 & $(0.1)$ & $(0.1)$ & $(0.0)$ & $(0.0)$ & 0.2 & 0.1 & 0.2 & 0.1 & 0.7 & 0.5 & 0.5 & 0.4 & 0.2 & 0.1 & 0.1 & 0.0 \\
\hline 4 & $(0.1)$ & $(0.1)$ & $(0.1)$ & $(0.1)$ & 0.3 & 0.1 & 0.2 & 0.0 & 0.3 & $(0.0)$ & 0.2 & $(0.0)$ & 0.2 & 0.1 & 0.1 & 0.1 \\
\hline 5 & $(0.1)$ & $(0.1)$ & $(0.0)$ & $(0.0)$ & 0.2 & 0.1 & 0.2 & 0.1 & 0.3 & $(0.1)$ & 0.1 & $(0.1)$ & 0.2 & 0.0 & 0.2 & 0.0 \\
\hline 6 & $(0.1)$ & $(0.1)$ & $(0.1)$ & $(0.1)$ & 0.2 & 0.1 & 0.2 & 0.1 & 0.3 & $(0.0)$ & 0.2 & $(0.0)$ & 0.2 & $(0.0)$ & 0.1 & $(0.1)$ \\
\hline 7 & $(0.1)$ & $(0.1)$ & $(0.0)$ & $(0.0)$ & 0.2 & 0.1 & 0.2 & 0.0 & 0.3 & $(0.0)$ & 0.2 & $(0.0)$ & 0.2 & $(0.1)$ & 0.1 & $(0.1)$ \\
\hline 8 & (0.1) & $(0.1)$ & $(0.1)$ & (0.1) & 0.2 & 0.1 & 0. & 0.0 & 0.2 & (0.1) & 0.1 & $(0.1)$ & 0.0 & 0.0 & 0.0 & 0.0 \\
\hline 9 & (0.1) & (0.1) & $(0.1)$ & $(0.1)$ & 0.3 & $(0.0)$ & 0.2 & $\begin{array}{c}(0.0) \\
\end{array}$ & 0.5 & $(0.2)$ & 0.4 & $(0.2)$ & 0.2 & \begin{tabular}{l|l}
0.0 \\
\end{tabular} & 0.0 & $\begin{array}{l}(0.0) \\
\end{array}$ \\
\hline 10 & $(0.1)$ & $(0.1)$ & $(0.1)$ & $\begin{array}{l}(0.1) \\
\end{array}$ & 0.3 & 0.1 & 0.2 & 0.1 & 0.5 & 0.0 & 0.3 & 0.0 & 0.2 & $(0.1)$ & 0.1 & $(0.1)$ \\
\hline 11 & $(0.1)$ & $(0.1)$ & $(0.1)$ & $(0.1)$ & 0.3 & 0.1 & 0.2 & 0.0 & 0.9 & 0.6 & 0.7 & 0.4 & 0.3 & (0.3) & 0.2 & $(0.2)$ \\
\hline 12 & (0.1) & $(0.1)$ & $(0.0)$ & $(0.0)$ & 0.2 & $(0.0)$ & 0.2 & 0.0 & 0.8 & 0.3 & 0.6 & 0.2 & 0.2 & $(0.3)$ & 0.2 & $(0.2)$ \\
\hline 13 & \begin{tabular}{l|}
$(0.1)$ \\
\end{tabular} & (0.1) & $(0.1)$ & $(0.1)$ & 0.3 & 0.0 & 0.3 & 0.0 & 0.2 & $(0.2)$ & 0.2 & $(0.2)$ & 0.2 & $(0.3)$ & 0.1 & $(0.2)$ \\
\hline 14 & $(0.2)$ & $(0.2)$ & $(0.1)$ & $(0.1)$ & 0.3 & $(0.0)$ & 0.2 & $(0.0)$ & 0. & $(0.2)$ & 0.2 & $(0.2)$ & 0.3 & $(0.3)$ & 0.2 & $(0.3)$ \\
\hline 15 & $(0.2)$ & $(0.2)$ & $(0.1)$ & $(0.1)$ & 0.3 & 0.1 & 0. & 0.1 & 0. & $(0.3)$ & 0.4 & $(0.2)$ & 0.1 & $(0.0)$ & 0.2 & 0.0 \\
\hline 16 & $(0.1)$ & $(0.1)$ & $(0.1)$ & (0.1) & 0.3 & 0.1 & 0.2 & 0.0 & 0.5 & 0.1 & 0.5 & 0.1 & 0.2 & $(0.1)$ & 0.2 & $(0.1)$ \\
\hline Houston & (0.1) & $(0.1)$ & $(0.0)$ & $(0.0)$ & 0.1 & $\begin{array}{l}(0.1) \\
\end{array}$ & 0.1 & $\begin{array}{l}(0.0) \\
\end{array}$ & 0.3 & $(0.0)$ & 0.2 & 0.0 & 0.0 & $(0.1)$ & 0.0 & $\begin{array}{l}(0.1) \\
\end{array}$ \\
\hline Phoenix & $(0.1)$ & $(0.1)$ & $(0.1)$ & $(0.1)$ & 0.3 & 0.0 & 0.2 & 0.0 & 0.3 & $(0.2)$ & 0.3 & $(0.2)$ & 0.1 & $(0.1)$ & 0.2 & $(0.1)$ \\
\hline Atlanta & $(0.1)$ & $(0.1)$ & $(0.0)$ & $\begin{array}{l}(0.0) \\
\end{array}$ & 0.2 & 0.1 & 0.2 & 0.1 & 0.1 & $\begin{array}{l}(0.1) \\
\end{array}$ & 0.1 & $(0.1)$ & 0.2 & $(0.1)$ & 0.2 & $(0.1)$ \\
\hline Minneap & (0.1) & (0.1) & (0.0) & $(0.0)$ & 0.3 & $(0.1)$ & 0.2 & $\begin{array}{c}(0.0) \\
\end{array}$ & 0.3 & 0.2 & 0.1 & 0.1 & 0.1 & $(0.0)$ & 0.0 & $(0.0)$ \\
\hline Chicago & $(0.1)$ & $(0.1)$ & $(0.0)$ & $\begin{array}{l}(0.0) \\
\end{array}$ & 0.2 & 0.1 & 0.2 & 0.1 & 0.4 & 0.3 & 0.3 & 0.3 & 0.2 & 0.2 & 0.1 & 0.1 \\
\hline Wash DC & $(0.1)$ & (0.1) & $(0.0)$ & $(0.0)$ & 0.2 & $(0.0)$ & 0.1 & 0.0 & 0.6 & 0.4 & 0.7 & 0.3 & 0.2 & (0.1) & 0.2 & 0.0 \\
\hline
\end{tabular}

Table 40.

Percentage Peak Demand Savings. Baseline and EC with horizon exterior obstruction.

Comparison to best commercially available window (F). Baseline daylight and shading condition defined in table.

EC defined with daylight control as defined in Table. EC has no interior shades.

Window-to-wall ratio $=0.3$

\begin{tabular}{|c|c|c|c|c|c|c|c|c|c|c|c|c|c|c|c|c|}
\hline \multirow{2}{*}{\begin{tabular}{c|} 
Zone \\
B Daylight?
\end{tabular}} & \multicolumn{4}{|l|}{ North } & \multicolumn{4}{|l|}{ East } & \multicolumn{4}{|l|}{ South } & \multicolumn{4}{|l|}{ West } \\
\hline & $\mathrm{N}$ & $\mathrm{N}$ & $\mathrm{Y}$ & $\mathrm{Y}$ & $\mathrm{N}$ & $\mathrm{N}$ & $\mathrm{Y}$ & $\mathrm{Y}$ & $\mathrm{N}$ & $\mathrm{N}$ & $\mathrm{Y}$ & $\mathrm{Y}$ & $\mathrm{N}$ & $\mathrm{N}$ & $\mathrm{Y}$ & $\mathrm{Y}$ \\
\hline B Shade? & $\mathrm{N}$ & $\mathrm{Y}$ & $\mathrm{N}$ & $\mathrm{Y}$ & $\mathrm{N}$ & $\mathrm{Y}$ & $\mathrm{N}$ & $\mathrm{Y}$ & $\mathrm{N}$ & $\mathrm{Y}$ & $\mathrm{N}$ & $\mathrm{Y}$ & $\mathrm{N}$ & $\mathrm{Y}$ & $\mathrm{N}$ & $\mathrm{Y}$ \\
\hline E Daylight? & $\mathrm{N}$ & $\mathrm{N}$ & $\mathrm{Y}$ & $\mathrm{Y}$ & $\mathrm{N}$ & $\mathrm{N}$ & $\mathrm{Y}$ & $\mathrm{Y}$ & $\mathrm{N}$ & $\mathrm{N}$ & $\mathrm{Y}$ & $\mathrm{Y}$ & $\mathrm{N}$ & $\mathrm{N}$ & $\mathrm{Y}$ & $\mathrm{Y}$ \\
\hline \multicolumn{17}{|l|}{ Climate } \\
\hline 1 & (1.6) & (1.6) & $(1.4)$ & (1.3) & 4.4 & 4.4 & 3.7 & 3.7 & 9.4 & 6.3 & 9.4 & 6.1 & 3.3 & 3.2 & 2.9 & 2.7 \\
\hline 4 & (2.8) & \begin{tabular}{l|}
$(2.8)$ \\
\end{tabular} & (2.5) & $(2.5)$ & 5.8 & 2.0 & 4.3 & 0.9 & 5.5 & $(0.3)$ & 4.7 & $(0.1)$ & 4.0 & 2.2 & 3.4 & 1.8 \\
\hline 5 & $(2.7)$ & $(2.4)$ & $(0.6)$ & $(0.7)$ & 5.2 & 3.4 & 4.6 & 1.9 & 5.4 & $(1.4)$ & 3.6 & $(2.3)$ & 5.5 & 0.9 & 4.9 & 0.5 \\
\hline 6 & (2.6) & (2.5) & $(1.8)$ & (1.7) & 4.5 & 2.6 & 4.0 & 2.4 & 6.1 & $(0.9)$ & 4.7 & $(0.9)$ & 4.6 & $(1.0)$ & 1.9 & (1.6) \\
\hline 7 & (2.1) & (2.0) & (1.3) & (1.5) & 4.9 & 1.4 & 4.2 & 1.2 & 5.1 & $(0.3)$ & 4.4 & $(0.6)$ & 5.1 & \begin{tabular}{l|l}
$(1.6)$ \\
\end{tabular} & 2.2 & (2.6) \\
\hline 8 & $(2.2)$ & $(2.2)$ & (1.7) & (1.7) & 4.5 & 2.0 & 1.7 & 0.6 & 4.3 & (2.8) & 2.6 & (3.2) & 0.6 & 0.6 & 0.3 & 0.3 \\
\hline 13 & $(2.7)$ & (2.9) & $(2.1)$ & (3.1) & 5.9 & 0.2 & 6.3 & 0.4 & 3.6 & (3.1) & 3.6 & $(3.7)$ & 3.1 & $(6.7)$ & 3.0 & $(5.0)$ \\
\hline 14 & (3.9) & (3.9) & (3.5) & $(3.4)$ & 5.4 & $(0.3)$ & 4.7 & $(0.5)$ & 5.6 & (4.3) & 4.6 & $(4.7)$ & 4.6 & $(6.2)$ & 4.0 & (5.9) \\
\hline 15 & (3.9) & $(4.0)$ & (3.7) & (3.6) & 5.9 & 2.5 & 5.3 & 2.7 & 8.0 & $(4.7)$ & 6.9 & (4.5) & 2.2 & $\begin{array}{l}(0.1) \\
\end{array}$ & 3.4 & 0.8 \\
\hline 16 & (3.0) & (3.1) & $(2.5)$ & $(2.6)$ & 5.6 & 1.2 & 5.3 & 1.1 & 9.6 & 2.9 & 10.0 & 3.4 & 3.8 & $(2.7)$ & 4.3 & (2.6) \\
\hline Houston & (1.4) & (1.4) & $(0.9)$ & $(0.8)$ & 1.6 & $(1.2)$ & 1.7 & $(0.4)$ & 5.8 & $(0.9)$ & 5.0 & 0.0 & 0.6 & (2.7) & 0.6 & $(2.0)$ \\
\hline Phoenix & (3.3) & (3.4) & (3.1) & $(3.2)$ & 5.1 & 0.0 & 4.2 & 0.2 & 5.7 & (3.7) & 6.1 & $(3.7)$ & 1.7 & (1.8) & 2.9 & (2.1) \\
\hline Atlanta & (1.5) & $(1.4)$ & (1.1) & (1.1) & 4.1 & 2.6 & 3.8 & 2.7 & 1.9 & $(2.0)$ & 1.9 & $(2.7)$ & 3.8 & $(2.4)$ & 3.6 & (1.3) \\
\hline Minneap & (1.8) & (1.8) & $(0.9)$ & $(0.9)$ & 5.4 & $(2.4)$ & 4.0 & $(1.2)$ & 6.8 & 4.1 & 3.2 & 2.1 & 1.9 & $(0.3)$ & 0.9 & $(0.3)$ \\
\hline Chicago & (1.9) & $(2.0)$ & $(1.2)$ & $(1.2)$ & 5.0 & 2.2 & 4.0 & 1.6 & 8.2 & 6.9 & 8.8 & 6.8 & 3.4 & 3.3 & 2.0 & 2.0 \\
\hline Wash DC & (2.2) & (2.1) & $(1.0)$ & $(0.9)$ & 3.4 & $(0.8)$ & 3.2 & 0.1 & 12.2 & 8.6 & 14.9 & 8.1 & 4.1 & $\begin{array}{ll}(1.3) \\
\end{array}$ & 4.4 & 1.0 \\
\hline
\end{tabular}


Table 41.

Peak Demand Savings (W/ft). Baseline with horizon exterior obstruction.

Comparison to best commercially available window (F). Baseline daylight and shading condition defined in table.

EC defined with daylight control as defined in Table. EC has no interior shades.

Window-to-wall ratio=0.6

\begin{tabular}{|c|c|c|c|c|c|c|c|c|c|c|c|c|c|c|c|c|}
\hline Zone & North & & & & East & & & & South & & & & West & & & \\
\hline B Daylight? & $\mathrm{N}$ & $\mathrm{N}$ & $\bar{Y}$ & $\mathrm{Y}$ & $\mathrm{N}$ & $\mathrm{N}$ & $\bar{Y}$ & $\mathrm{Y}$ & $\mathrm{N}$ & $\mathrm{N}$ & $\bar{Y}$ & $\bar{Y}$ & $\mathrm{~N}$ & $\mathrm{~N}$ & $\mathrm{Y}$ & $\bar{Y}$ \\
\hline B Shade? & $\mathrm{N}$ & $\mathrm{Y}$ & $\mathrm{N}$ & $\mathrm{Y}$ & $\mathrm{N}$ & $\mathrm{Y}$ & $\mathrm{N}$ & $\mathrm{Y}$ & $\mathrm{N}$ & $\mathrm{Y}$ & $\mathrm{N}$ & $\mathrm{Y}$ & $\mathrm{N}$ & $\mathrm{Y}$ & $\mathrm{N}$ & $\mathrm{Y}$ \\
\hline E Daylight? & $\mathrm{N}$ & $\mathrm{N}$ & $\mathrm{Y}$ & $\mathrm{Y}$ & $\mathrm{N}$ & $\mathrm{N}$ & $\mathrm{Y}$ & $\mathrm{Y}$ & $\mathrm{N}$ & $\mathrm{N}$ & $\mathrm{Y}$ & $\mathrm{Y}$ & $\mathrm{N}$ & $\mathrm{N}$ & $\mathrm{Y}$ & $\mathrm{Y}$ \\
\hline E Shade? & $\mathrm{N}$ & $\mathrm{N}$ & $\mathrm{N}$ & $\mathrm{N}$ & $\mathrm{N}$ & $\mathrm{N}$ & $\mathrm{N}$ & $\mathrm{N}$ & $\mathrm{N}$ & $\mathrm{N}$ & $\mathrm{N}$ & $\mathrm{N}$ & $\mathrm{N}$ & $\mathrm{N}$ & $\mathrm{N}$ & $\mathrm{N}$ \\
\hline \multicolumn{17}{|l|}{ Climate } \\
\hline 1 & 0.1 & 0.1 & 0.1 & 0.1 & 0.9 & 0.4 & 0.7 & 0.3 & 1.3 & 0.8 & 1.1 & 0.7 & 0.8 & $(0.1)$ & 0.6 & $(0.1)$ \\
\hline 2 & $(0.0)$ & $(0.0)$ & 0.0 & 0.0 & 0.9 & 0.4 & 1.0 & 0.4 & 2.2 & 1.3 & 2.2 & 1.3 & 1.0 & 0.2 & 1.1 & 0.2 \\
\hline 3 & 0.1 & 0.1 & 0.1 & 0.1 & 1.0 & 0.4 & 0.8 & 0.3 & 1.9 & 1.3 & 1.7 & 1.1 & 1.1 & 0.4 & 0.9 & 0.3 \\
\hline 4 & 0.0 & 0.0 & 0.0 & 0.0 & 1.0 & 0.4 & 1.0 & 0.4 & 1.3 & 0.6 & 1.3 & 0.7 & 1.1 & 0.4 & 1.0 & 0.3 \\
\hline 5 & 0.0 & 0.1 & 0.0 & 0.0 & 1.0 & 0.2 & 0.7 & 0.0 & 1.5 & 0.7 & 1.4 & 0.6 & 1.1 & 0.4 & 1.0 & 0.3 \\
\hline 6 & 0.0 & 0.1 & 0.0 & 0.1 & 0.8 & 0.2 & 0.8 & 0.2 & 1.3 & 0.6 & 1.2 & 0.6 & 1.1 & 0.4 & 1.1 & 0.3 \\
\hline 7 & $(0.0)$ & 0.0 & 0.0 & 0.0 & 1.0 & 0.6 & 0.9 & 0.5 & 1.4 & 0.9 & 1.3 & 0.8 & 1.2 & 0.4 & 1.1 & 0.3 \\
\hline 8 & 0.1 & 0.1 & 0.1 & 0.1 & 0.9 & 0.3 & 0.8 & 0.3 & 1.4 & 0.4 & 1.4 & 0.4 & 0.7 & 0.1 & 0.8 & 0.1 \\
\hline 9 & 0.0 & 0.0 & 0.1 & 0.1 & 1.0 & 0.2 & 1.0 & 0.3 & 1.6 & 0.3 & 1.6 & 0.3 & 1.0 & 0.2 & 0.9 & 0.2 \\
\hline 10 & 0.0 & 0.0 & 0.0 & 0.0 & 0.9 & 0.3 & 1.0 & 0.3 & 1.8 & 0.6 & 1.8 & 0.6 & 1.0 & 0.4 & 1.0 & 0.5 \\
\hline 11 & $(0.0)$ & $(0.0)$ & 0.0 & 0.0 & 1.0 & 0.4 & 0.9 & 0.3 & 1.7 & 0.8 & 1.5 & 0.6 & 1.1 & 0.1 & 1.0 & 0.1 \\
\hline 12 & 0.1 & 0.1 & 0.1 & 0.1 & 1.0 & 0.4 & 1.0 & 0.4 & 1.8 & 0.8 & 1.8 & 0.8 & 1.1 & 0.2 & 1.2 & 0.2 \\
\hline 13 & 0.0 & 0.1 & 0.0 & 0.0 & 1.1 & 0.2 & 1.1 & 0.2 & 1.4 & 0.5 & 1.4 & 0.5 & 1.1 & $(0.1)$ & 1.1 & $(0.1)$ \\
\hline 14 & $(0.0)$ & 0.0 & 0.0 & $(0.0)$ & 1.0 & 0.2 & 0.8 & 0.2 & 1.2 & 0.2 & 1.0 & 0.1 & 0.9 & 0.0 & 0.7 & $(0.0)$ \\
\hline 15 & $(0.0)$ & $(0.0)$ & 0.0 & 0.0 & 1.1 & 0.3 & 1.0 & 0.3 & 1.2 & 0.2 & 1.1 & 0.2 & 0.7 & 0.3 & 0.8 & 0.2 \\
\hline 16 & 0.0 & 0.0 & 0.0 & 0.0 & 1.0 & 0.4 & 0.9 & 0.4 & 0.5 & 0.3 & 0.4 & 0.3 & 0.7 & 0.1 & 0.7 & 0.1 \\
\hline Houston & 0.1 & 0.1 & 0.2 & 0.2 & 0.5 & 0.0 & 0.4 & $\begin{array}{l}(0.0) \\
\end{array}$ & 1.0 & 0.6 & 0.8 & 0.5 & 0.7 & 0.0 & 0.4 & $(0.0)$ \\
\hline Phoenix & 0.0 & 0.0 & $\begin{array}{l}(0.1) \\
\end{array}$ & $(0.1)$ & 0.9 & 0.3 & 0.9 & 0.3 & 0.8 & 0.1 & 0.6 & 0.1 & 0.5 & $\begin{array}{l}(0.1) \\
\end{array}$ & 0.6 & (0.1) \\
\hline Atlanta & 0.1 & 0.1 & 0.1 & 0.1 & 1.0 & 0.5 & 1.0 & 0.5 & 1.4 & 0.4 & 1.4 & 0.5 & 0.7 & 0.1 & 0.8 & 0.1 \\
\hline Minneap & 0.1 & 0.1 & 0.0 & 0.0 & 1.3 & 0.4 & 1.3 & 0.4 & 1.5 & 1.2 & 1.3 & 1.0 & 1.1 & 0.4 & 1.0 & 0.3 \\
\hline Chicago & 0.1 & 0.1 & 0.1 & 0.1 & 0.9 & 0.4 & 0.9 & 0.4 & 1.1 & 1.1 & 0.9 & 1.0 & 0.8 & $(0.2)$ & 0.8 & $(0.2)$ \\
\hline Wash DC & 0.1 & 0.1 & 0.1 & 0.1 & 0.8 & 0.0 & 0.8 & 0.1 & 1.2 & 0.8 & 0.9 & 0.5 & 1.0 & 0.1 & 1.0 & 0.1 \\
\hline
\end{tabular}

Table 42.

Percentage Peak Demand Savings. Baseline with horizon exterior obstruction.

Comparison to best commercially available window (F). Baseline daylight and shading condition defined in table.

EC defined with daylight control as defined in Table. EC has no interior shades.

Window-to-wall ratio $=0.6$

\begin{tabular}{|c|c|c|c|c|c|c|c|c|c|c|c|c|c|c|c|c|}
\hline \multirow{2}{*}{\begin{tabular}{c|} 
Zone \\
B Daylight?
\end{tabular}} & \multicolumn{4}{|l|}{ North } & \multicolumn{4}{|l|}{ East } & \multicolumn{4}{|l|}{ South } & \multicolumn{4}{|l|}{ West } \\
\hline & $\mathrm{N}$ & $\mathrm{N}$ & $\mathrm{Y}$ & $\mathrm{Y}$ & $\mathrm{N}$ & $\mathrm{N}$ & $\mathrm{Y}$ & $\mathrm{Y}$ & $\mathrm{N}$ & $\mathrm{N}$ & $\mathrm{Y}$ & $\mathrm{Y}$ & $\mathrm{N}$ & $\mathrm{N}$ & $\mathrm{Y}$ & $\mathrm{Y}$ \\
\hline B Shade? & $\mathrm{N}$ & $\mathrm{Y}$ & $\mathrm{N}$ & $\mathrm{Y}$ & $\mathrm{N}$ & $\mathrm{Y}$ & $\mathrm{N}$ & $\mathrm{Y}$ & $\mathrm{N}$ & $\mathrm{Y}$ & $\mathrm{N}$ & $\mathrm{Y}$ & $\mathrm{N}$ & $\mathrm{Y}$ & $\mathrm{N}$ & $\mathrm{Y}$ \\
\hline E Daylight? & $\mathrm{N}$ & $\mathrm{N}$ & $\mathrm{Y}$ & $\mathrm{Y}$ & $\mathrm{N}$ & $\mathrm{N}$ & $\mathrm{Y}$ & $\mathrm{Y}$ & $\mathrm{N}$ & $\mathrm{N}$ & $\mathrm{Y}$ & $\mathrm{Y}$ & $\mathrm{N}$ & $\mathrm{N}$ & $\mathrm{Y}$ & $\mathrm{Y}$ \\
\hline \multicolumn{17}{|l|}{ Climate } \\
\hline 1 & 2.8 & 3.0 & 2.4 & 2.6 & 17.7 & 7.8 & 16.2 & 6.6 & 22.0 & 14.6 & 22.4 & 14.6 & 13.2 & (1.9) & 12.6 & (1.6) \\
\hline 4 & 1.2 & 1.2 & 0.9 & 0.9 & 15.0 & 6.8 & 17.7 & 8.2 & 19.0 & 10.2 & 22.6 & 13.2 & 17.5 & 7.2 & 19.5 & 6.9 \\
\hline 5 & 1.1 & 1.5 & 1.5 & 1.4 & 16.6 & 3.6 & 14.9 & 0.9 & 21.8 & 10.9 & 24.4 & 11.8 & 19.5 & 8.7 & 20.4 & 7.4 \\
\hline 6 & 1.3 & 1.4 & 1.5 & 1.6 & 13.4 & 3.6 & 15.6 & 3.9 & 17.7 & 9.3 & 20.7 & 11.6 & 16.6 & 6.2 & 19.7 & 6.9 \\
\hline 7 & $(0.8)$ & 0.5 & 1.1 & 0.7 & 16.3 & 10.0 & 18.4 & 10.5 & 20.4 & 13.9 & 22.2 & 14.5 & 18.7 & 8.0 & 20.6 & 6.8 \\
\hline 8 & 1.4 & 1.4 & 1.8 & 1.8 & 13.8 & 4.9 & 16.0 & 5.6 & 18.3 & 5.7 & 21.4 & 7.0 & 11.4 & 2.1 & 14.1 & 3.0 \\
\hline 13 & 1.0 & 1.7 & 1.2 & 1.3 & 16.1 & 3.5 & 18.6 & 3.9 & 19.2 & 7.7 & 22.2 & 9.4 & 15.0 & $(1.2)$ & 17.5 & $(1.7)$ \\
\hline 14 & $(0.0)$ & 0.1 & 0.0 & $(0.1)$ & 12.6 & 3.0 & 12.8 & 3.6 & 14.9 & 2.2 & 14.5 & 2.0 & 11.2 & 0.5 & 10.8 & $(0.1)$ \\
\hline 15 & (1.0) & $(0.9)$ & 0.2 & 0.3 & 14.9 & 4.8 & 15.9 & 4.8 & 15.1 & 2.3 & 15.2 & 2.8 & 9.7 & 3.9 & 12.1 & 3.6 \\
\hline 16 & 0.9 & 0.8 & 0.1 & 0.0 & 14.0 & 6.3 & 15.2 & 6.7 & 8.2 & 4.7 & 8.2 & 6.3 & 10.7 & 1.4 & 11.2 & 0.9 \\
\hline Houston & 3.2 & 3.1 & 5.1 & 4.9 & 7.8 & 0.3 & 8.0 & $(0.8)$ & 15.4 & 9.4 & 14.8 & 9.1 & 10.2 & 0.0 & 8.2 & $(0.9)$ \\
\hline Phoenix & 0.3 & 0.3 & (1.5) & (1.7) & 12.5 & 4.0 & 14.2 & 5.3 & 10.9 & 0.9 & 9.5 & 1.6 & 6.5 & (2.0) & 8.5 & $(2.2)$ \\
\hline Atlanta & 3.4 & 3.4 & 3.8 & 3.8 & 14.9 & 8.0 & 17.7 & 9.8 & 19.1 & 7.1 & 22.4 & 8.8 & 11.6 & 1.1 & 15.0 & 2.5 \\
\hline Minneap & 2.1 & 2.1 & 0.6 & 0.7 & 20.3 & 7.0 & 22.9 & 7.7 & 23.7 & 19.7 & 24.7 & 19.9 & 18.6 & 7.1 & 20.9 & 6.2 \\
\hline Chicago & 2.2 & 2.3 & 2.7 & 2.7 & 15.3 & 7.5 & 17.5 & 8.3 & 18.2 & 18.6 & 19.2 & 20.2 & 12.6 & (2.8) & 14.9 & (3.8) \\
\hline Wash DC & 1.4 & 1.5 & 1.9 & 1.8 & 12.8 & 0.9 & 15.9 & 1.6 & 18.9 & 13.2 & 16.7 & 9.5 & 15.6 & 1.8 & 18.2 & 2.0 \\
\hline
\end{tabular}

